\title{
El retaule dominic del Roser a Pollença. El procés constructiu $i$ els seus artistes
}

\author{
Miquel Pou Amengual \\ Historiador de l'art \\ miquelpou@yahoo.es
}

Recepció: 31/03/2017, Acceptació: 29/05/2017, Publicació: 22/12/2017

RESUM

Aquest estudi, basat en la localització de nova documentació d'arxiu i d'uns altres manuscrits fins ara desconeguts, traça el procés constructiu del retaule major del convent del Roser de la localitat mallorquina de Pollença. A partir de les dades conegudes recentment, s'estableixen les seqüències constructives de la fabricació del retaule, així com la manera de funcionar del taller d'escultura de Joan Antoni Oms i dels artistes que en continuaren la creació. A més, l'anàlisi posa en context el procés de construcció del moble en relació amb altres treballs, tant dins d'aquesta població com en d'altres, i amplia el catàleg dels artistes que hi participaren. La investigació, en un primer apartat, fa una revisió de les fonts documentals que afectaren aquest convent, cosa que ha provocat confusions sobre l'obra que s'hi realitzà. A més, el present treball vol solucionar les llacunes que existien respecte a la peça i les atribucions parcials dutes a terme fins ara.

Paraules clau:

Oms; Andreu Carbonell; Esteve Sanxo; Rafel Torres; Pollença; dominics

\section{AbSTRACT}

The Dominican altarpiece of Roser in Pollença: The construction process and its artists

This study uses new archival documents to trace the construction of the main altarpiece of the Convent del Roser in the Mallorcan town of Pollença. With the new data, we trace the periods in which the altarpiece was constructed, as well as the functioning of the sculpture workshop of Juan Antoni Oms and other artists. In addition, the study reveals other works in the city and expands on the catalog of artists who participated in them. We review the documentary sources related to the convent, which have led to confusion or gaps in the research and which the present study attempts to resolve.

Keywords:

Oms; Andreu Carbonell; Esteve Sanxo; Rafel Torres; Pollença; Dominican Order 
A finals del segle XVI, es va fundar una comunitat de l'orde dominic a la població de Pollença (Mallorca). Arran d'aquesta fundació i després de diversos anys al municipi, es començà la construcció de tot un complex arquitectònic conventual per a la comunitat religiosa. El conjunt de les noves edificacions que es promogueren constava d'un convent amb claustre $\mathrm{i}$ diverses dependències per a habitatge, magatzems $\mathrm{i}$ altres elements, així com l'església, un projecte constructiu molt avançat a la segona dècada del segle XVII ${ }^{1}$. El recinte ha perviscut fins a l'actualitat, però va ser víctima de les desamortitzacions ocorregudes al segle XIX.

Una vegada tingueren avançada l'arquitectura del lloc, se n'inicià l'adquisició i la promoció dels elements decoratius i mobiliars. Pel que fa al nou temple, la construcció més important que cal tenir-ne en compte fou el retaule major dedicat a Nostra Senyora del Roser, nom que també havia adoptat aquest convent i que, a la vegada, es tractava d'una advocació, en la difusió de la qual, com veurem, l'orde dominic hi tenia un paper vinculant. El retaule serà l'obra que tractarem en aquest estudi.

La peça fou projectada per l'escultor Joan Antoni Oms Tomàs -l'escultor mallorquí de més renom en aquell moment - i se'n continuà la fabricació durant pràcticament un segle a càrrec d'altres obradors illencs. Amb tot això, i a causa del gruix temporal que afectà la construcció d'aquest moble, s'aprofitarà aquest estudi per desenvolupar altres artistes que hi participaren, no solament en aquest temple conventual, sinó també en el recinte parroquial del mateix municipi.

La contractació d'aquest retaule del Roser s'havia acordat entre els pares dominics i l'es- cultor Joan Antoni Oms. Fins ara, els estudis que hi han fet referència han pres com a base la Història de Pollensa que publicà l'historiador Mateu Rotger, un treball que no entrà en l'assumpte més enllà de la citació genèrica a les dades i a l'autor principal. Aquest estudi de Rotger constituí la font bàsica per relacionar l'obrador dels Oms amb aquest temple, si bé, des de fa pràcticament un segle fins ara, no ha tingut lloc cap revisió de les fonts conventuals ni coetànies sobre la construcció d'aquest moble, excepte una única actualització l’any I97 I $\mathrm{amb}$ un altre replec d'informació bàsica sobre diversos autors i treballs artístics sobre l'illa, on s'ampliaren els artífexs que havien intervingut en la peça amb els noms dels dos fills de Joan Antoni (Joan i Gaspar), juntament amb un altre, Miquel Carbonell².

Pel que fa a treballs específics d'història de l'art, podem trobar el retaule analitzat, històricament $\mathrm{i}$ artísticament, en investigacions $\mathrm{i}$ publicacions més recents, com ara l'obra que tractà sobre l'escultura del sis-cents mallorquí així com unes altres de marcat caràcter acadèmic i curricular ${ }^{4}$. En aquests estudis, ja s'hi advertia de l'existència d'aspectes que necessitaven una revisió, a més de la constància de llacunes que han donat peu a algunes hipòtesis atributives, a causa, en gran part, de les habituals generalitzacions que es produïren en la primera historiografia mallorquina. Durant els primers anys del segle XX, molts dels treballs sobre art religiós es trobaven en mans del clergat, que, en molts de casos, era l'únic que disposava de les dades d'arxiu necessàries o de l'interès per fer algun treball històric, sobretot en referència a llocs religiosos. Per tant, gràcies a la nova documentació i als canvis de classificació d'altres manuscrits que oferirem, en aquesta anàlisi que 
presentam, s'ampliarà el coneixement artístic i documental d'aquesta època i, específicament, en la població de Pollença.

D'altra banda, com a tota promoció d'aquesta envergadura i, sobretot, en una comunitat religiosa d'ingressos periòdics però limitats, les construccions i les diverses realitzacions es feien sense terminis temporals o elements constructius gaire clars i, en alguns casos, canviats després d'alguns anys. En aquest mateix retaule del Roser, n'hi veurem un de documentat: la substitució de les pintures del bancal per uns baixos relleus. Un altre cas que també desenvoluparem serà la participació que tingué l'escultor Joan Antoni per a l'acabament d'un altre retaule que havia deixat sense finalitzar l'escultor Antoni Verger vint anys abans ${ }^{5}$.

\section{Una revisió de les fonts i la primera obra de Joan Antoni Oms Tomàs per al convent dominic pollencí}

En primer lloc, abans de desenvolupar el retaule del Roser, cal fer una revisió general de la catalogació de les fonts arxivístiques que tractarem, no en referència al contingut, perquè aquest aspecte es farà dins els apartats corresponents i serà la base de l'argumentació d'aquest estudi, sinó al centre original al qual pertanyen. Per algun motiu, hi va haver diversos documents d'aquest convent que foren inventariats quan passaren a formar el dipòsit dels nous arxius de manera errònia, sobretot respecte als documents conservats a l'Arxiu Diocesà de Mallorca (ADM) i a l'Arxiu del Regne de Mallorca (ARM), que contemplaren alguna documentació conventual com a pròpia de la parròquia, que, en certa manera, es devia referir al lloc d'on provenien els manuscrits, però no pas a qui pertanyien.

Ja hem dit que el convent dels dominics de Pollença sofrí, com tants d'altres, els processos de desamortització, per la qual cosa una gran part del seu patrimoni quedà escampat o repartit entre diverses institucions o persones, a més del que es perdé definitivament. Aquest fet provocà, també, la disgregació $i$ la descontextualització de l'arxiu conventual, que va anar a parar a diferents llocs. Per tant, la catalogació posterior i l'estudi d'alguns d'aquests escrits ha donat lloc a confusions de localització d'algunes de les obres artístiques que s'hi troben registrades o, també, a la no localització si se cercava com a documentació conventual.

Una part de l'arxiu conventual es diposità a l'arxiu parroquial de la localitat. El recinte conventual passà a mans de la institució municipal,

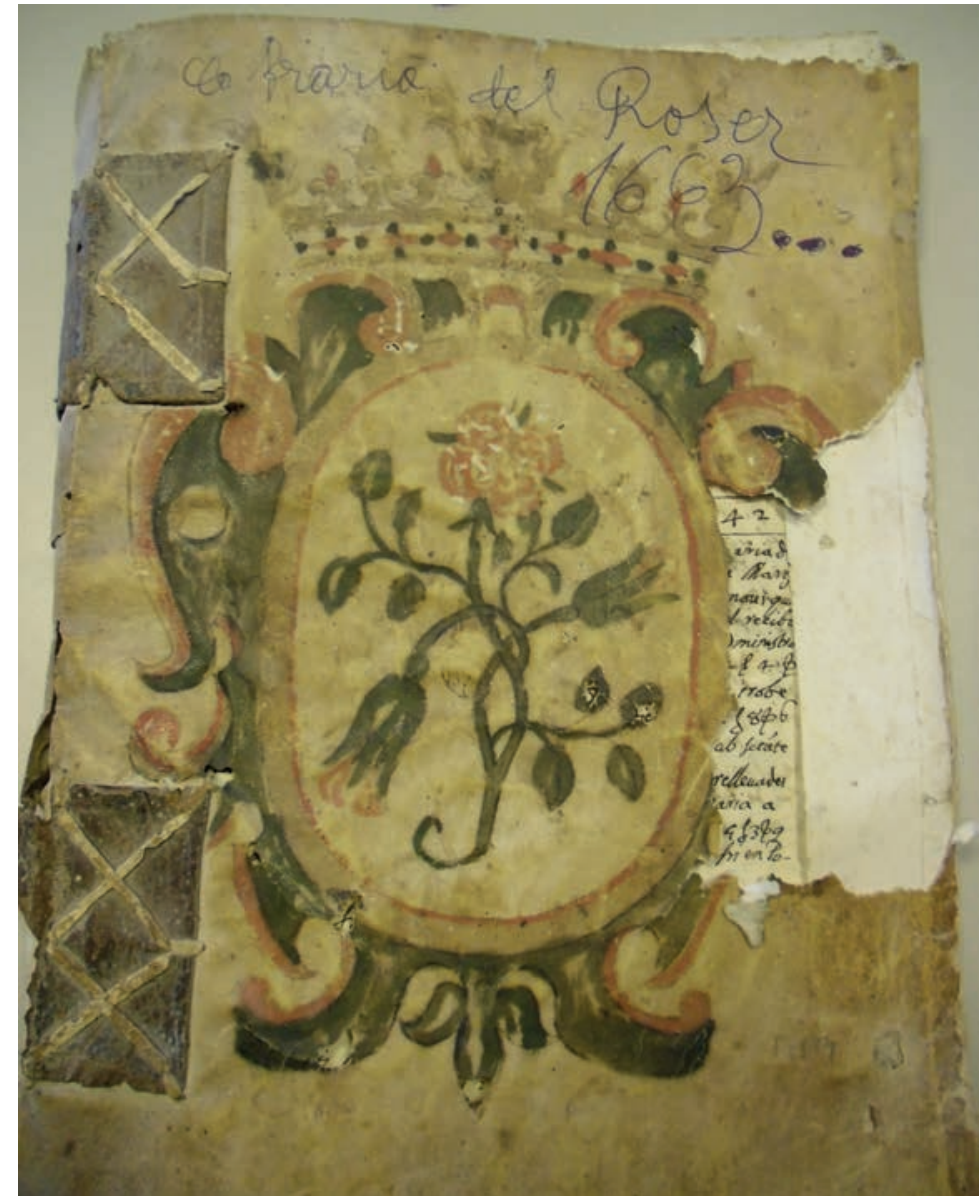

Figura 1.

Llibre de la Confraria de Nostra Senyora del Roser. Arxiu Diocesà de Mallorca (APP. 459).

i el temple, pròpiament, quedà en propietat del Bisbat de Mallorca. En referència al material d'arxiu, no en coneixem l'abast de la desfeta, però, en concret, pel que ens interessa, ens referirem a la documentació que pertanyia a la Confraria del Nom de Jesús i a la Confraria de la Mare de Déu del Roser. Considerem que alguns escrits d'aquestes dues advocacions formen part del fons arxivístic, però es varen confondre i s'identificaren com a llibres i manuscrits parroquials, amb la qual cosa es va fer creure, als possibles interessats sobre el tema, que era documentació d'estudi per a les capelles d'aquest altre recinte. El temple parroquial, per exemple, no sembla que hagi tingut mai ni capella ni retaule del Roser, emperò sí que consta documentació dedicada a aquesta advocació dins l'apartat de confraries i comptes de l'inventari documental diocesà ${ }^{6}$. A la vegada, i per complicar-ne la investigació, amb el temps, algunes unitats documentals es disgregaren i se separaren físicament.

Una vegada feta aquesta petita reflexió sobre el problema que ha comportat la disgregació de l'arxiu conventual, podem passar a analitzar la documentació objecte d'aquest estudi. La 
necessitat de dur un bon registre de les noves promocions artístiques va fer crear els llibres comptables pertinents. La Confraria del Roser en degué generar dos o més. D’aquests, només se n'ha conservat un de sencer d'aquesta època a l'Arxiu Diocesà de Mallorca, on també es conserven quaderns fragmentats. El còdex és un bell manuscrit decorat amb una portada policromada amb el símbol de la confraria: un escut coronat i l'emblema de la rosa en el centre ${ }^{7}$ (figura I). L'altra confraria, la del Nom de Jesús, just després de la seva fundació conventual, també va muntar un nou llibre comptable que s'ha conservat, encara que l'interior sembla que hagi sofert algun capgirament. Fou dipositat a l'Arxiu del Regne de Mallorca.

Aquesta vegada, igual com hem explicat en referència a la Confraria del Roser, el llibre dedicat a l'advocació del Nom de Jesús s'agafà com a propi del temple parroquial. D'aquesta manera, i també com a revisió $\mathrm{i}$ introducció dels treballs que començà l'escultor Joan Antoni Oms per a aquest recinte conventual, s'ha de fer constar que, l'any I634, l'artista ja havia realitzat una figura del Nom de Jesús per als dominics. Aquí és on es produeix un primer canvi, no respecte a l'obra creada per l'escultor Oms, sinó pel recinte per a la qual fou concebuda. Aquesta vegada, la confusió sobre el lloc es deu al fet que, a la seva època, el còdex fou titulat literalment Llibre de la Confraria del Nom de Jesús de la vila de Pollença, una designació escrita a la portada que en generalitzava l'àmbit a tot el municipi. Per tant, una vegada tret de l'entorn i del context de l'orde que el guardava, es classificà com a propi de la parròquia. En canvi, nosaltres entenem que no és així. Si s'observa el clergat que repetidament es transcriu en els comptes $i$ en els fulls interiors, ens adonem que, si bé molts s'inicien amb el terme rector com a màxim dirigent de la confraria, aquest càrrec no té res a veure amb la figura moderna de responsable parroquial, sinó que es refereix al responsable de la germandat o de la comunitat dominica (prior). A més, els titulars sempre fan referència als frares dominics (prior fra Joan Nadal, fra Guillem Martí, etc.), no a clergues de l'església, si bé aquesta parròquia, aleshores, encara era conduïda per membres de l'Orde de Sant Joan. De manera més concreta, en algunes citacions que hi apareixen, ja es relaciona directament la confraria amb el convent dels dominics: «[...] fra. Jaume Juan Nadal de l'orde de Predicadors rector de la Confraria del SSm Nom de Jesús del Convt de la Vila de Pollença[...]»"

Amb tot això, per tant, no cal fer cap repetició dels registres documentals que es mencionen en matèria artística, perquè ja foren transcrits en un treball anterior dedicat a l'advocació del Nom de Jesús a Mallorca ${ }^{9}$. En resum, sobre l'aspecte artístic, a més de la fabricació d'una figura del Nom de Jesús, que, encara que ressituant-la, tampoc sembla que s'hagi conservat, la confraria, anys després de fabricar la imatge, va fer elaborar un retaule sencer a Antoni i Jaume Ballester. Una vegada enllestit aquest nou moble, el pintor Jaume Comelles s'encarregà de realitzar alguns treballs secundaris i de pintar catorze pintures dedicades als misteris del Nom de Jesús. Aquest retaule s'ha conservat a la primera capella a la dreta del presbiteri i consideram que és un dels primers fets per al convent.

Aquesta obra inicial que hem localitzat, la podrem tractar breument en base a la revisió documental, però, abans, per a aquest cas en concret, convé introduir i desenvolupar les distintes formes de manifestació iconogràfica que podien tenir els mobles d'aquesta advocació. En el segle XVII, i ja partint de dues centúries abans, l'advocació al Nom de Jesús arribà al seu màxim apogeu. Mallorca no fou aliena a aquest moviment i s'implantà a moltes de les seves poblacions. Les construccions d'aquests retaules solien acompanyar-se amb el monograma de Jesús (IHS) posat en escuts, pintures o esculpit. Les primeres confraries de l'illa ja eren presents en el convent dominic de Ciutat de Mallorca els anys I 58 I i I 597 en el convent de Pollença. Pel que fa a matèria d'iconografia $\mathrm{i}$ d'imatges pròpies, era compatible la mescla de diversos tipus o figures per decorar els retaules. No només s'hi podia posar una figura del Nin Jesús que, d'altra banda, solia ser l'habitual, sinó que també hi havia la possibilitat d'adoptar imatges del Crucificat o del Corpus Cristi. Per exemple, quant a la presència d'una figura central del Crucificat, la trobaríem en els casos de les viles mallorquines de Petra o Sineu ${ }^{10}$, com també a la zona peninsular, posem per cas, a la catedral de Còrdova.

Cal precisar, a més, que la Confraria del Nom de Jesús d'aquest convent no és la primera que trobam documentada en aquesta població. La seva parròquia ja hi havia dedicat un altre retaule ${ }^{11}$. El I 582 , la confraria parroquial pagava per pintar-lo: «Alonso Ruiz, pintor confesa rebre dels obrers de la Conf. del Nom de Jesús 6311 [...] en dues partides [...] resten a pagar [...] a compliment de les vuitanta lliures degudes a dit pintor [...] si per cas lo retaule [...] Jo Alonso Ruiz, pintor» ${ }^{12}$. I a la meitat del segle següent (I660), l'escultor Rafel Torres s'encarregava de fabricar una figura del Bon Jesús per a la parroquial pollencina, obra per a la qual cobrà 33 lliures $^{13}$. En aquest darrer cas, de totes maneres, no sabem si la imatge i el promotor corresponien a la mateixa advocació.

Una vegada localitzat el llibre de la Confraria del Nom de Jesús d'aquest convent, així com l'ampliació dels elements que podrien contenir els retaules d'aquesta advocació, sembla plausi- 
ble i bastant probable que l'obra feta pels Ballester i les pintures de Comelles corresponguin al primer dels retaules laterals d'aquest temple (figura 2). Com podem veure, la peça presenta un crucificat al nínxol central, mentre que, a l'escut central de l'àtic, hi trobam el monograma de Jesús. D'altra banda, els catorze misteris del pintor Comelles es distribueixen al voltant del nínxol central. El moble va seguir l'ordenació pròpia de la primera meitat del segle XVII, amb una predel.la i un cos central de tres carrers dividits en columnes centrals anellades i acanalades o en espiral. Tot el conjunt s'acabà amb un àtic separat per estípits. Els centrals eren de base bulbosa i els extrems, de fulla vegetal.

L'escultor Antoni Ballester (I 590-1658), l'autor d'aquest retaule, era de la vila de Manacor, un artífex habitual dins el cercle dels dominics, la formació del qual s'ha situat dins el taller de Jaume Blanquer. Aquest retaule de Pollença no va ser l'únic que realitzà per a aquest orde religiós, perquè en va fer un altre per al convent de la seva vila. Per tant, ens segueix confirmant la bona connexió laboral i la coneixença del seu treball entre els dominics. Aquest fet també el veurem més endavant amb l'escultor Andreu Carbonell. El pintor Jaume Comelles, que elaborà les pintures del retaule, encara resulta un autor de catàleg poc conegut. Se sap que era el pintor de la Universitat del Regne de Mallorca i que, per aquest motiu, havia elaborat diversos retrats de personatges illustres mallorquins (Rafel Cotoner, Gran Mestre de l'Orde de Malta; el bisbe Joan Estelrich, i Antoni Creus Ponç). A més, també sabem que realitzà una pintura de la Mare de Déu del Pilar per al monestir de les Jerònimes de la Ciutat de Mallor$\mathrm{ca}^{14}$. El pintor estava casat amb Antònia Palmer i participava en les reunions del gremi d'artistes. Quan morí (I663), encara tenia algunes estampes de mostra, i l'escultor Pere Pou comprà un llibre d'art durant la venda dels encants del difunt ${ }^{15}$.

Les catorze pintures de Jaume Comelles s'aprecien distribuides al voltant del retaule: tres a la predel-la (un episodi de la Nativitat, la Circumcisió i l'Ascensió), tres més a l'àtic (Jesús davant Herodes Antipas, el Davallament i la Coronació d'Espines) i quatre a cada un dels dos carrers laterals (el Bateig, la Santa Cena, en el temple o Jesús arrestat, $\mathrm{i}$ diversos episodis de Crist ressuscitat). Comelles, pel que es pot veure, elaborava una pintura molt colorista, amb una bona composició i distribució de les formes. La majoria d'aquestes pintures es treballaren dins espais interiors o en paisatges en el fons. En el nínxol central, on es posà la imatge del Crucificat, es pintà un cel amb amorets i, a davall, un grup d'orants representant els dos estaments: a la banda esquerra, els clergats i els religiosos presidits per un papa agenollat, i, a la

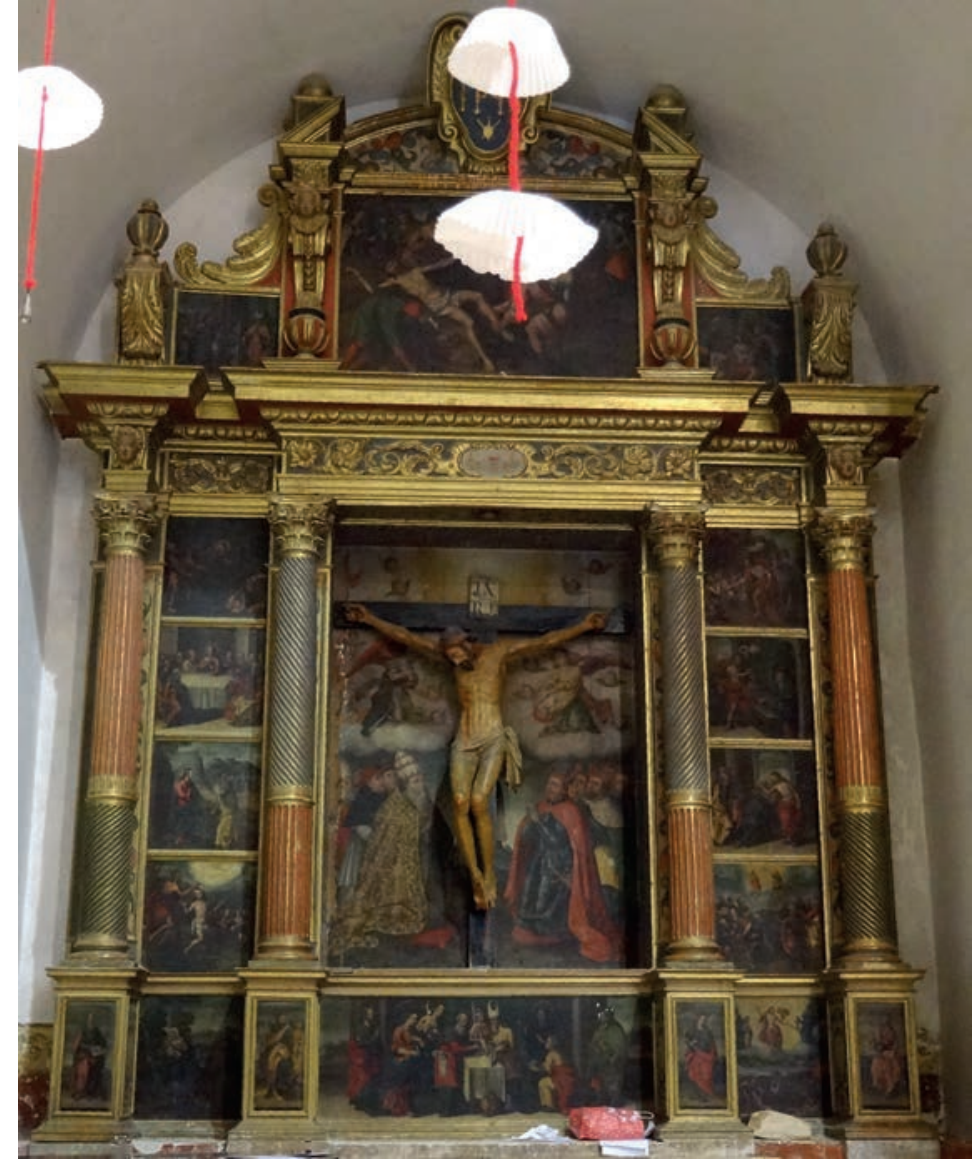

Figura 2.

Retaule del Nom de Jesús (1638-1645). Convent de Nostra Senyora del Roser. Pollença.

dreta, l'estament de la noblesa i de l'aristocràcia amb un monarca armat al primer pla. Sobre la datació de la pintura, si es correspon a l'època coetània de la intervenció del pintor Comelles, les dues figures d'orants principals podrien inspirar-se o fer referència, encara que sia en representació abstracta, als personatges en actiu d'aquell moment: Urbà VIII o Innocenci X, pel que $f a$ al papat, i Felip IV, per al monarca.

A banda de la figura del Nin Jesús que realitzà Joan Antoni Oms, no sabem si aquest escultor, o Ballester, elaborà la del Sant Crist Crucificat que presideix el moble. En tot cas, els comptes no apunten a cap més imatge. Si ens adequam a l'estilisme de l'escultor Oms, la imatge es desmarca del Crucificat que va fer uns quants anys després (I643) per a l'església d'Alaró. En tot cas, la peça de Pollença està treballada de manera molt més estilitzada i amb un volum més lleuger que la realitzada per Oms a Alaró, que té una magnitud i un pes corporal més gran. D'altra banda, a les traces i a l'anatomia (la musculatura abdominal, el rostre i els genolls), no deixa d'apreciar-se un control de la tècnica, del coneixement del cos i de la seva bona elaboració escultòrica. La figura del Nin Jesús d'Oms degué perdurar fins al segle 
XIX, perquè, en alguns inventaris d'aquesta centúria, segurament fets amb motiu de la desamortització, hi ha algunes figures que són citades, explícitament, amb aquest nom: dues figures del Nin Jesús, una de la Verge del Roser (que deu ser, com veurem, la que realitzà Gaspar Oms unes quantes dècades després), una de sant Domingo, una de sant Vicenç Ferrer, una altra de sant Jacint i una altra de santa Rosa ${ }^{16}$.

A nivell documental, s'ha de fer menció que els fulls comptables d'aquesta obreria no es refereixen en cap moment a la figura d'un Nin Jesús, sinó a l'advocació del Nom de Jesús, citat de vegades com a Bon Jesús, però sí que, en el primer moment, quan Oms fabricà la imatge, es registraren complements de vestimenta propis per a una figura del Nin Jesús. De totes maneres, la imatge del Sant Crist en aquest retaule ja hi era l'any I650, quan la confraria pagava 37 sous per «[...] Item per trenta y dos palms de gasse per un vel per davant el St. Christo I 2 anelletes y quatre canes llandera $[\ldots]{ }^{17}$.

Finalment, entre els altres artífexs que treballaren per a aquesta confraria, hi podem incorporar l'escultor Joan Sagarra. El i60 I, aquest escultor els havia fet un tabernacle $i$ en cobrava les partides pendents ${ }^{18}$. Una obra que, pel que coneixem, no s'ha conservada. L'escultor Sagarra té pocs treballs que hagin perdurat dels que sabem que obrà. Per exemple, se n'ha perdut una figura de sant Miquel per a la població d'Artà i un retaule de sant Cristòfol fet per a Binissalem. Només es conserva el portal major que traçà l'escultor Miquel Quetgles per a la parroquial de Felanitx ${ }^{19}$. Aquests dos autors estaven dins l'òrbita de l'escultor Antoni Verger, un altre creador al qual ens referirem més endavant.

La formació de les agrupacions religioses dedicades al Nom de Jesús i al Roser feta dins el convent de Pollença quedà també plasmada en un altre llibre registral d'aquesta època (segle XVII). En aquest altre còdex, hi quedà el testimoni dels registres i les llistes de tots els confrares de totes dues confraries que s'hi anaven inscrivint de manera continuada. Una peça també treballada amb una bella portada, al centre de la qual es pintà la creu dominica ${ }^{20}$.

\section{La intervenció del taller Oms}

\section{L'escultura de Joan Antoni Oms i el seguiment a càrrec del taller}

Ja hem dit que l'escultor Joan Antoni Oms Tomàs (1600-1667) representa el personatge més reconegut de la seva època i que gaudí d'un ampli ressò en l'estatuària mallorquina del segle XVII. La seva formació s'inicià el i6 16, quan entrà d'aprenent en el taller de Jaume Blanquer, i altres vegades ja se n'ha analitzat la carrera professional $^{21}$. Així i tot, podem aprofitar per completar la coneixença dels seus deixebles i d'altres tasques realitzades per ell, no específicament de treball escultòric. Una vegada obrí el taller, a més dels aprenents que ja en coneixíem, com Damià Creuades o Antoni Carbonell, aquest darrer només vinculat $i$, com veurem, la seva formació dins el taller dels Oms ja es pot donar com un fet documentat, hi hem d'incloure un altre d'anterior, com fou Francesc Ballil Amorós. Aquest nou aprenent, fill de Margalida Amorós i del selleter Agustí Ballil, ingressà en el taller de l'escultor el I $640^{22}$. Ballil devia ser qui després va començar a treballar tant d'escultor com de daurador, però, malauradament, no va fer feina més enllà de 1652 , quan morí a causa de la pesta ${ }^{23}$. En el taller familiar dels Oms, sovint hi devien entrar aprenents nous, perquè, uns quants anys després (I645), el pintor Gaspar Oms II n'acceptava un altre: Francesc Brotat, de la vila de Muro, encartat a càrrec de Miquel Gomila, curador de l'heretat del seu pare ${ }^{24}$.

Al catàleg que coneixem d'aquest escultor, hi podem aportar un altre treball que realitzà per a la parroquial de Pollença durant aquesta època. Un poc abans de començar el retaule conventual, va elaborar una peça reliquiari, segurament una escultura amb el cap de sant Jaume, per poc més de dotze lliures ${ }^{25}$. D’altra banda, tengué tasques de taxador en escultura i també el podem trobar l'any 1656, quan, amb el pintor Joan Baptista Llodrà (†口677), va ésser escollit encarregat per designar el cost que comportava l'acabament del retaule del $\mathrm{Da}$ vallament del convent de Sant Francesc de la Ciutat de Mallorca. Aquest retaule era l'obra que havia llegat i que havia deixat a mig fabricar un altre escultor: Antoni Verger. Verger establí en el testament l'obligació d'acabar-lo, però uns vint anys després de la seva mort encara no s'havia conclòs. Andreu Santandreu, el clergue responsable de les causes pies d'aquella època, va tenir coneixement que alguns dels béns heretats de l'escultor s'havien venut, sense que els beneficiaris tenguessin pensat usar els diners per a pagar la feina pendent del retaule inacabat. El novembre de I655, Santandreu va fer una suplicació i n'exposà la qüestió: Verger, una vegada començat el retaule, va designar l'escultor Jaume Blanquer perquè el finalitzàs, però aquest o bé no hi treballà més o tampoc l'arribà a enllestir ${ }^{26}$. Segons es transcrigué, Verger havia manat testamentàriament que «[...] conforme la dita traça, tinch donada a mestre Jaume Blanquer posant en lo altar [...] lo meu retaule del davallament [...] que tinch comprat en Valentia que sera de mida de deset palms d'Altaria 
i dotze d'amplaria y lo mes que sap dit mestre Jaume Blanquer $[\ldots]]^{27}$. Tot aquest tema ja ha estat estudiat, però sembla que s'hi produeixen algunes novetats que n'amplien la coneixença $^{28}$. L'escultor Verger havia dit que l'herència no passàs als hereus fins que s'hagués acabat la capella, però l'hereu, el Dr. Antoni Verger, ja hi tenia accés; per exemple: la pintura del $\mathrm{Da}$ vallament que Verger havia comprat a València ja havia estat venuda, i al retaule, a més d'estar inacabat, ja li faltava la peça titular. Santandreu, aprofitant la venda de terres del patrimoni de l'escultor, va sol-licitar que els beneficis anessin, primer, a acabar el retaule i, per això, s'havia de designar dos experts per taxar el preu de finalitzar el moble $e^{29}$. La petició del suplicant va ser acceptada el febrer de r 656 i se'n designaren els dos taxadors: Joan Antoni Oms i Joan Baptista Llodrà. Joan Antoni Oms dugué l'informe davant el vicari general de la diòcesi, Joan Aranda i Palatio, i establí les tasques que calia realitzar i el cost que suposava: «[...] y he mirat un retaula que esta derrera lo altar maior en la capella de Antoni Verger sculptor y mirat dit retaule dich que en ell manca una guarnitio per el quadro maior de enmig y deurarlo en tota la perfectio y pintar el pedestal de baix y fer hi un sacrari deurat conforme demana dit retaule y aci dich a ma conciència que dita feyna que se ha de fer val trescentes vuytanta lliures [...]». El pintor Llodrà va fer el mateix, presentà el pressupost de les pintures que s'havien de realitzar i les taxà per 95 lliures: 60 lliures per a la pintura central del Davallament, io lliures per a cada una de les pintures dels dos carrers laterals i is lliures més per a la de la banqueta ${ }^{30}$.

La qüestió passà a la Reial Audiència. L'abril de 1655 , en prenia part una de les afectades, Margalida Verger, que devia ser la muller del mercader Pere Joan Bauçà ${ }^{31}$. L'any següent continuava la qüestió oberta amb un nou expedient on es parlava del cas en el punt $3^{32}$. Sobre el retaule de Verger, podem suposar, per tant, que, a més del treball fet per ell mateix, per Blanquer i per Pere Mestre Colom, algun altre escultor degué finalitzar-lo cap al I656 i el pintor Josep Onofre Borràs en realitzà les pintures.

S'ha de precisar que, en vida de l'escultor Verger, el seu patrimoni ja dugué problemes amb la seva família. El rafal que provocà la denúncia que hem vista ja havia estat motiu de conflicte amb el nebot l'any 1633. De les actuacions que n'han perdurat, se'n traspua que l'hereu, citat com a misser, era un personatge bastant vanitós i feia publicitat falsa d'haver aconseguit tota l'herència de l'escultor en vida. L'escultor Verger, en adonar-se del fet, va redactar una acta pública on ho desmentia i recriminava la mala actuació de l'hereu ${ }^{33}$.

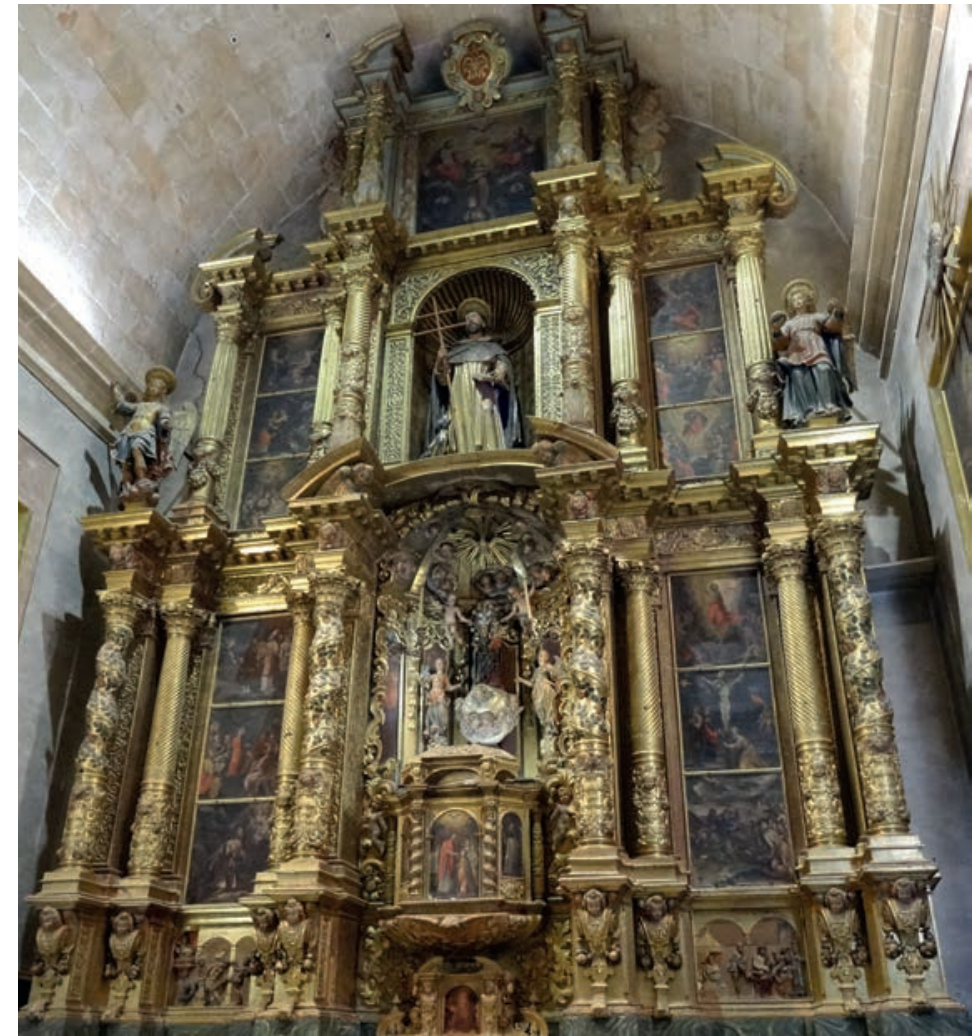

Figura 3.

Retaule de Nostra Senyora del Roser. Convent dels dominics. Pollença.

Si tornam al treball de Joan Antoni Oms dut a terme a Pollença, a més del retaule dominic que tractarem, l'escultor també hi realitzà el retaule major de la parròquia, que el i 800 fou substituit per l'actual, portat del temple de Monti-Sion de la mateixa població. Però, tal com explicarem en referència al moble dominic, el procés constructiu d'aquest altre moble degué ser igualment costós i llarg, perquè Miquel i Antoni Carbonell encara hi treballaren en els anys quaranta del segle XVIII. El 1742, aquests s'encarregaren d'acabar-lo i d'eixamplar-lo a mida segons el presbiteri, a més, en pintaren la pastera i part del sagrari. De totes maneres, la feina d'aquests Carbonell a Pollença presenta un altre aspecte més original, perquè trobaríem el primer exemple aplicat dels coneixements que el pintor Miquel Carbonell tenia sobre les matemàtiques i la gnomònica. Miquel Carbonell era considerat un artista no només pràctic en l'art de la pintura, sinó també en coneixements tècnics i teòrics en referència al color, a l'anatomia, a la teoria matemàtica i sobre rellotges solars. D'aquests darrers exemples, se sabia una obra seva de compendi matemàtic i una altra de gnomònica ${ }^{34}$. L'aplicació pràctica d'aquesta matèria la trobaríem en els tres rellotges de sol que el pintor dissenyà i realitzà per a la vila de Pollença el mateix any que treballava per al retaule parroquial ${ }^{35}$. 


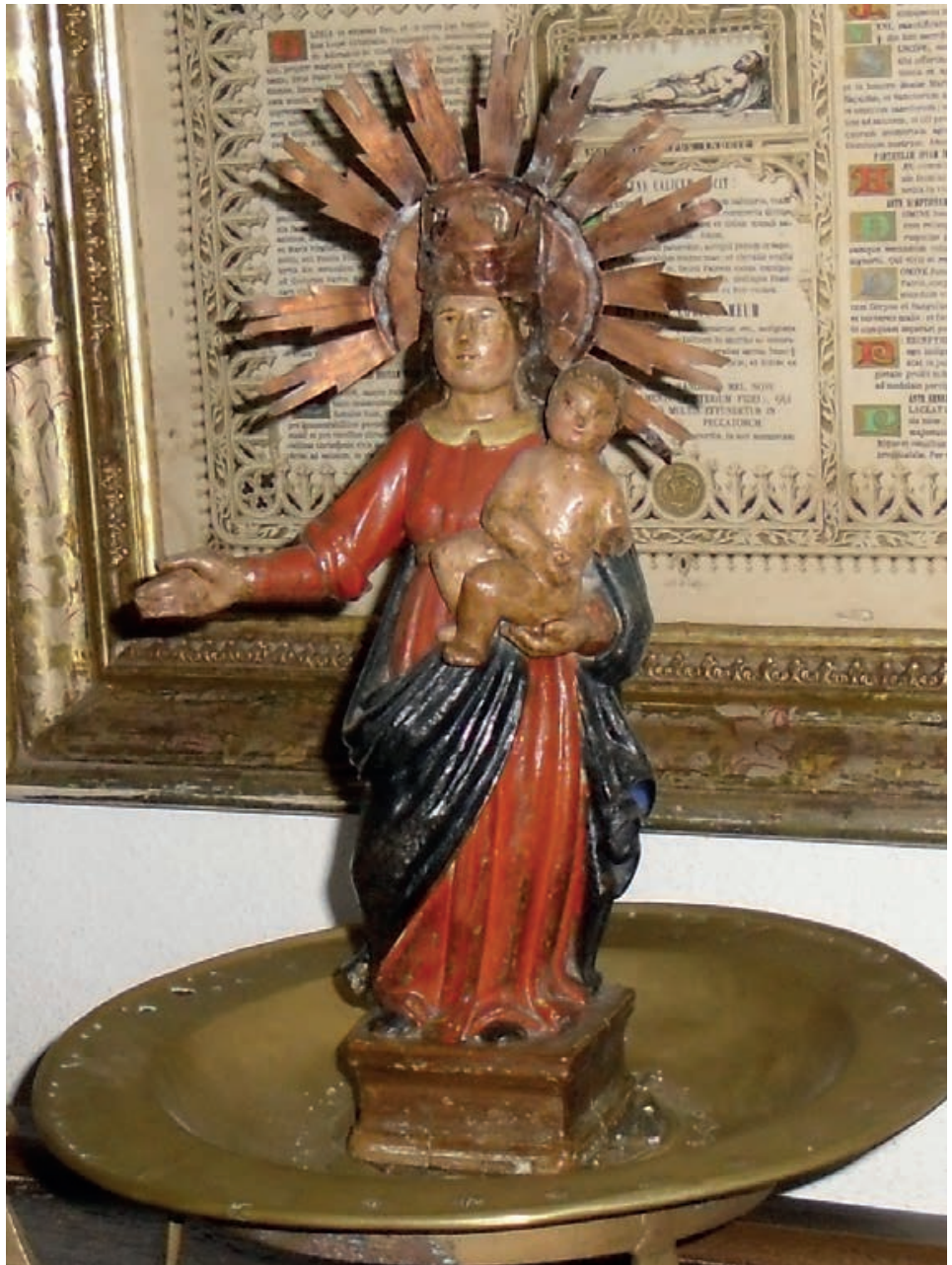

Figura 4

Figura de bacina. Nostra Senyora del Roser. Taller dels Oms. 1667. Parròquia de Pollença.

Aquestes peces devien tenir, en diversa mesura, algun treball escultòric. No en sabem la localització, si és que encara perduren. Darrerament, s'han estudiat noves obres d'aquest obrador a la vila d'on era nadiu el pintor Miquel (Maria de la Salut). Encara que aquest darrer estudi no acabà d'aclarir, malgrat l'intent de recerca, les dades de relació filial d'aquests dos Carbonell (Miquel i Antoni) amb el treball fet a Pollença, sabem que eren pare i fill ${ }^{36}$.

Una vegada introduit l'escultor Joan Antoni Oms, podem passar a tractar el retaule major del convent de Pollença (figura 3). La fàbrica s'inicià cap al $165 \mathrm{I}$. Aquest any, la confraria promotora ja havia començat a comprar fusta de poll «[...] per lo retaula que se ha de fer $[\ldots]{ }^{37}$. Respecte a aquest primer aspecte d'aconseguir la matèria primera, s'ha de fer esment a l'abundosa fusta que es recollia dins la mateixa població. Les despeses constants que, de manera exclusiva, fan referència a la compra de fusta de poll per al moble mostren que era adquirida als veïns: a Mateu Vila (3 11.), a Ramon Pont
(8 11.), a Joan Pellicer (4 11.), a Can Axartell i al Molí de les Rates (7 1l., 2 s.), a Antoni Cabanellas (7 11.), a Rafel de Pedruxell, etc. La fusta es tractava i es feia serrar també al serrador del poble ${ }^{38}$. De fet, i com veurem més endavant, la imatge de sant Domingo d'aquest retaule, així com gran part de l'obra escultòrica, no només es va fer al taller d'escultura que els Oms tenien a la capital mallorquina, sinó que també degueren muntar un taller provisional dins la mateixa localitat. Segurament, en el recinte conventual, a més d'allotjar-hi els artífexs que s'hi desplaçaren per treballar-hi, hi adaptaren un petit espai per tractar-hi les peces. L'exemple de la fusta per a la imatge de sant Domingo n'és específica, perquè el I66I la confraria ja va adquirir la matèria primera per fabricar-la: «Item per aportar ab un carro dos trosos de poll de son Sion per fer la figura de St. Domingo [...] 211» $»^{39}$.

La contractació efectiva, en tot cas, per la banda dels promotors amb Joan Antoni Oms va passar el I653, quan es va desplaçar l'escultor a Pollença per establir-ne les condicions ${ }^{40}$. Joan Antoni coincidia en aquelles dates amb l'escultor Pere Pou, que realitzava unes tasques menors per al pas processional de la Coronació d'Espines, una peça realitzada segurament per al temple parroquial ${ }^{41}$. Una vegada establert el contracte, es començaren a pagar els treballs a l'escultor: 53 lliures el 1653 i unes altres partides l'any següent ${ }^{42}$. La pulcritud dels comptes ens informen sobre la manera de treballar que tenia aquest taller d'escultura. A més, hi devien col-laborar diverses persones, tant escultors com pintors, no sols de la mateixa nissaga. Més endavant, veurem com el treball dels dos fills era habitual, i durant aquest primer moment se citaven escultors i pintors de manera genèrica: «Item per lloguer de dos cavalcadures per a aportar a Ciutat dos esculptors y les aynes vint y un sous; Item per port de dos pintors [...] I $5 \mathrm{~s} \gg^{43}$.

Hem trobat narrat el primer període del procés constructiu gràcies a un memorial que varen fer els responsables dominics de la confraria (Fra Pere Bua [?] i Fra Guillem Martí). El text ens descriu el començament i l'evolució del retaule durant els primers deu anys:

20 juliol [1654?] P. Mestre fr. Pera Bua [?] de Confraria del Ro[ser] al Fra. Guillem Marti [...] Homs fa p[?] Gaspar de mestre Joan Antoni Homs esculptor y treball [...] fins als 9 de Octubre de dit any, y acabar la banqueta.

Proseguis el retaule y vingue dit Joan Homs y son Germà Gaspar 6 de Octubre 1655 y tornaren fer el disapte de Nadal y ferense lo [pilars] plans 


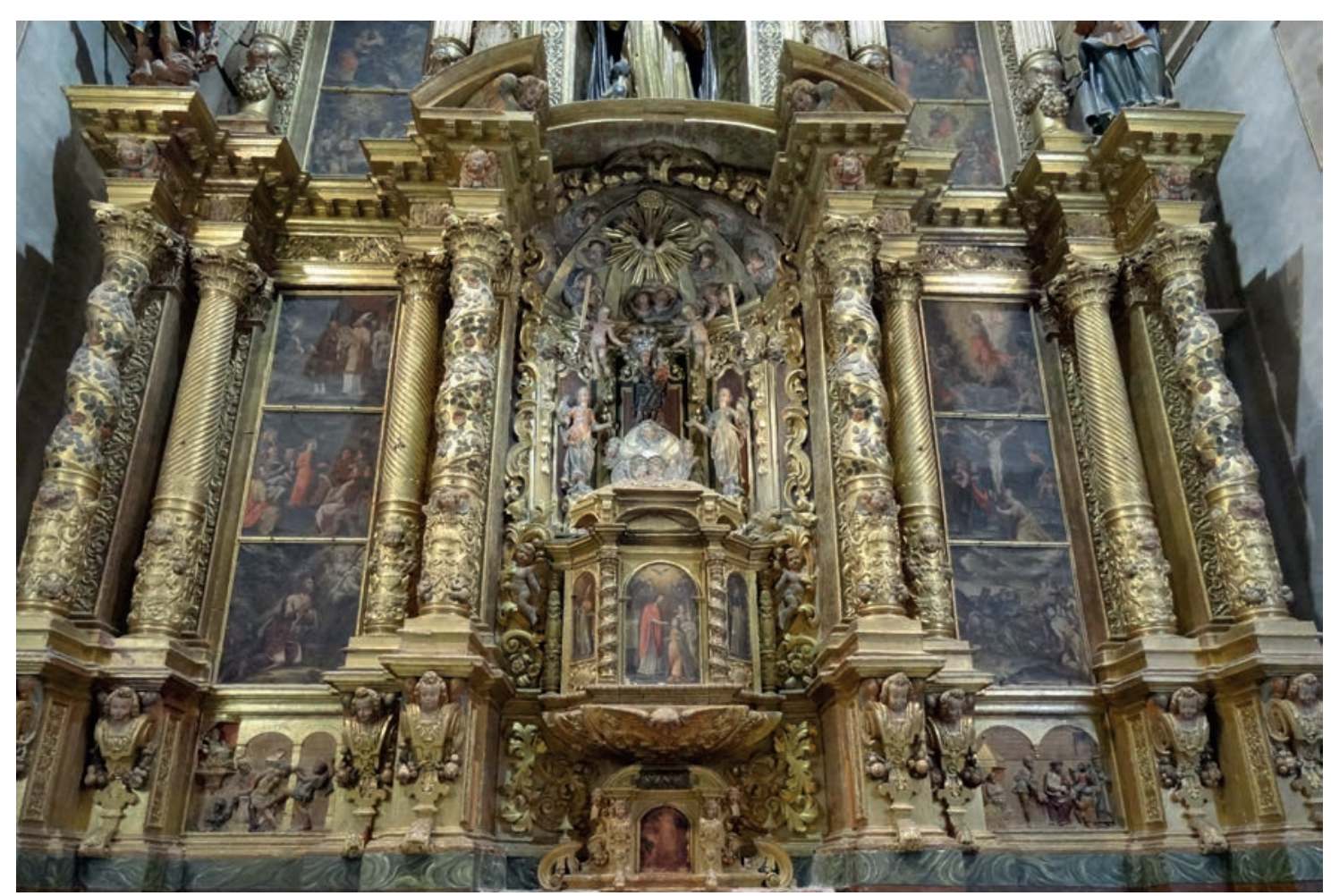

Figura 5.

Cos central. Sagrari (1688-1697) i cambril (1742-1753) del retaule de Nostra Senyora del Roser.

$3^{\circ}$ Vingue dit Joan Homs als 2 I febrer 1657 y son Germà Gaspar vingué a 17 abril de dit any y anarensen a Ciutat als 26 juny [?] de pst. Any y en aquest temps feren les vuit columnes del orde primer.

$4^{\circ}$ Vingue dit Joan Homs fa [?] als 8 octubre I658 y anasen per les festes de Nadal y torn per la Quaresma y acaba la guarnissa major els I9 març I659

$5^{\circ}$ Vingué Gaspar Homs ab companyia de me. Antoni Carbonell esculptor als 2I setembre I66I[?] y anarensen a Ciutat als 2I de octubre, y feren los pilars plans de la $2^{\mathrm{a}}$ orde

$6^{\circ}$ Vingue mestre Homs ab compañia de son fill Gaspar y un torner als 21 de abril 1663 ferense les columnes del segon orde als 4 maig sen ana lo [me. H]oms y vingué als 6 un altre esculptor, y als 28 maig vingué un fuster de Ciutat, sens me. Costa acabaren tota la segona orde als 3 agost de dit any ${ }^{44}$

Aquest manuscrit elaborat pels frares dominics ens és interessant per exposar la forma que tenia aquest obrador de treballar. Joan Antoni Oms, una vegada contractada la peça amb el preu i el contingut al qual ja ens hem referit l'any 1653 , començava a fer la feina juntament amb els altres membres del taller. Els fills tenien, com veim, una marcada tasca en referència a la construcció real i manual del moble. En el marge de pocs mesos, anaven a la població traslladant el material que es fabricava de l'obrador. A més, per les llargues temporades que hi passaven, no sols devien muntar les peces dutes del taller familiar, sinó que, en gran mesura, segurament també n'elaboraven in situ dins la mateixa localitat. A la feina del pare, com a la dels fills, veim que, de vegades, també hi colllaboraven uns altres artesans, per exemple: artesans del torn, que ajudaven a fabricar les peces i a muntar-les. Segons com, hi apareixen anomenats uns altres escultors. És el cas d'Antoni Carbonell.

L'escultor Antoni Carbonell va treballar per a aquest retaule amb Gaspar Oms. D'altra ban$\mathrm{da}$, ja havia estat relacionat amb l'obrador dels Oms, tant estilísticament com per haver-se localitzat documentalment, unes altres vegades, amb els components del taller i els colllaboradors, per exemple: amb el mateix Joan Antoni o amb l'escultor Creuades. Això afavorí la hipòtesi que hagués estat aprenent dins aquest taller. Una hipòtesi que creiem que es pot donar per confirmada, perquè, l'any I 638 , l'escultor Joan Antoni Oms i Antoni Carbonell apareixien de manera conjunta i seguida testimoniant en les darreres voluntats d'Elisabet Gallard, la muller d'un vidrier anomenat Bartomeu Calafat. En 


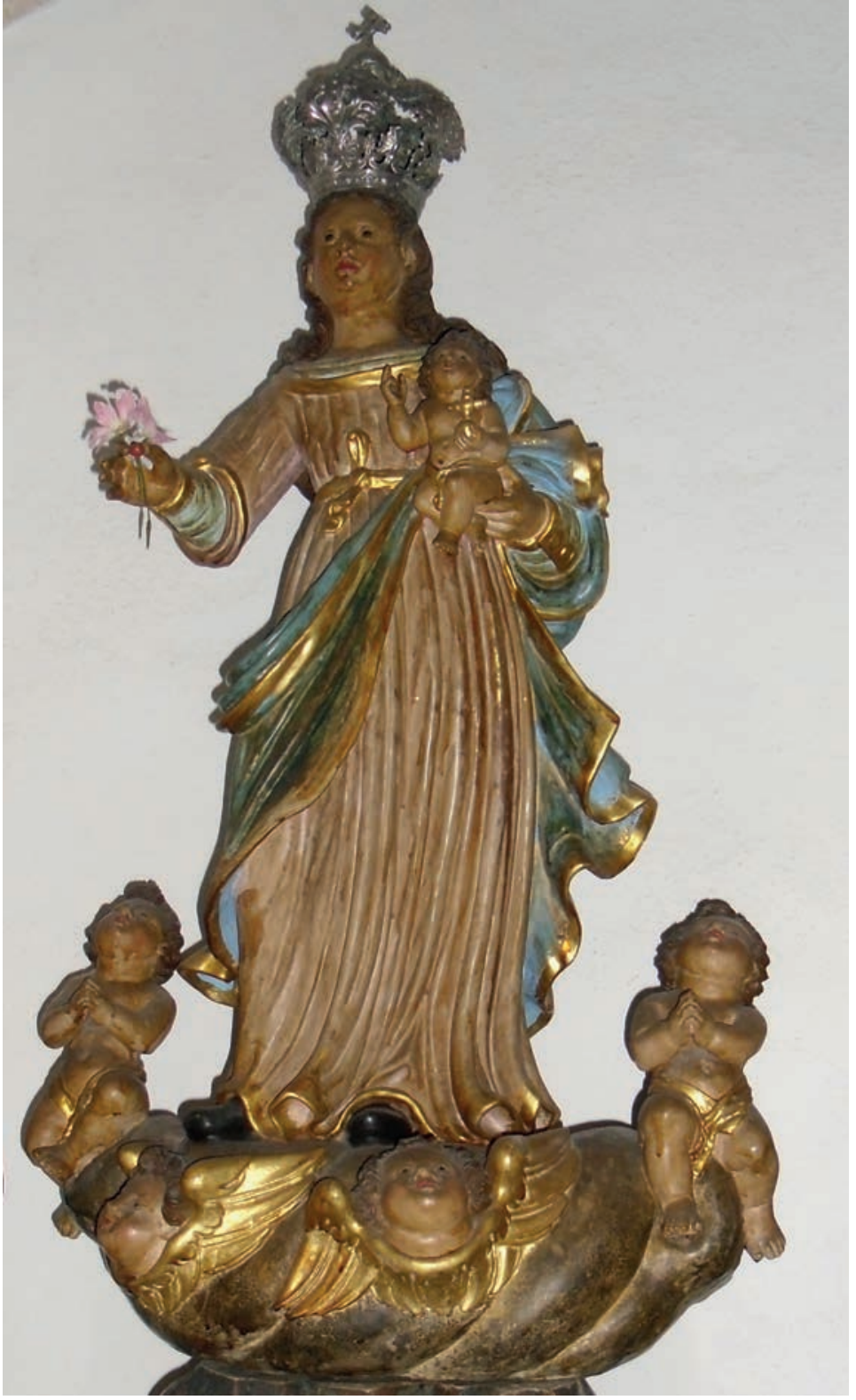

Figura 6.

Mare de Déu del Roser. Gaspar Oms Arbona, 1700. Sagristia parroquial de Pollença.

aquest cas, mentre l'escultor Oms era recollit amb el nom de la seva professió, seguidament, hi apareixia el nom d'Antoni Carbonell citat com a «[... practicant de dita art de sculptura $[\ldots] »^{45}$. D’aquesta manera, amb aquestes noves citacions, podem extreure les conclusions que Carbonell s'inicià en el món de l'escultura entrant d'aprenent amb Joan Antoni Oms, aproximadament, entre els anys i635 i i640. I una vegada acabada la formació i ja treballant d'escultor, a la dècada dels 40, no deixà la vinculació professional amb l'obrador formatiu.

Els documents citats no són els únics en què podem seguir localitzant els dos escultors de manera conjunta. En tenim d'altres exemples: el maig de 1647, Oms i Carbonell eren citats a petició del notari Nicolau Terrassa per fer de testimonis d'una acta d'alçament de preus del blat a la plaça de la Quartera, un document que havia demanat el paraire Rafel Ferrer. Altres vegades, se'l troba fent de testimoni notarial dels documents d'Antonina Sitjar, filla de l'escultor Damià i fillastre de Joan Antoni Oms ${ }^{46}$. Sobre Carbonell, sabem que es casà dues vegades. Amb la primera muller, Elisabet Sardà, tengué almenys un fill que feia de fuster a Mancor. I amb la segona, Catalina Sacares, tengué un altre fill, Jaume, que faria de pintor. Aquesta segona muller la podem trobar l'any I689 com a part d'un document notarial sobre els successors $\mathrm{i}$ l'herència del mossèn Jaume Torrens, un parent que tenia de la vila d'Inca ${ }^{47}$. L'any següent, poc després de morir l'escultor, Catalina va elaborar el testament fent marmessors el prior del convent de Nostra Senyora d'Ítria, on escollia també ser enterrada, i el fill pintor. Al fillastre fuster li deixava s lliures, mentre que al fill pintor el feia l'hereu universal ${ }^{48}$.

Joan Antoni Oms, com a cap del taller, entre la vinguda i l'anada dels fills a Pollença, anava cobrant per la feina que es feia al moble. El I663, ja havia rebut 600 lliures per a la construcció del moble. A més, diversos pintors també s'hi desplaçaren per completar el treball plàstic, segurament, per fer les primeres capes de bol i guix per a la futura policromia, estofat i daurat $^{49}$. Encara que la majoria de vegades era Joan Antoni Oms qui cobrava, algunes vegades, poques, trobam el fill Gaspar, que, posteriorment, es faria càrrec de la direcció d'aquest taller ${ }^{50}$.

El retaule major del Roser entrà dins una segona fase constructiva durant la dècada de I660. Des de I65 I fins a I663, s'elaborà i es pujà l'estructura amb els dos primers pisos i les columnes principals. En aquesta segona fase, l'escultor Joan Antoni sembla que, a poc a poc, deixà d'intervenir-hi i donà pas als altres membres de la família. Va ser quan en realitzaren les figures principals, el coronament i en començaren la decoració secundària. La mort de Joan Antoni Oms († I667) marcarà, finalment, el canvi definitiu en la direcció del projecte $\mathrm{i}$ l'aparició d'altres artistes del mateix obrador, o no, que seguiran amb el treball fins ben entrat el segle següent.

El i663, es pagaren tant els manobres per anar posant el retaule com el propi Oms, amb diners $\mathrm{i}$ amb espècies ${ }^{51}$. L'any següent, es va començar a fer la figura de Sant Domingo, la imatge central situada dins el nínxol del segon pis. El pes important del treball d'aquesta figura recaigué sobre el fill Joan: «Item a mestre Joan Homs o mes fer a Joan, fill del sobredit, ab diverses vegades quant feya St Domingo s 11 IOS ${ }^{52}$, una feina per a la figura en què degué 


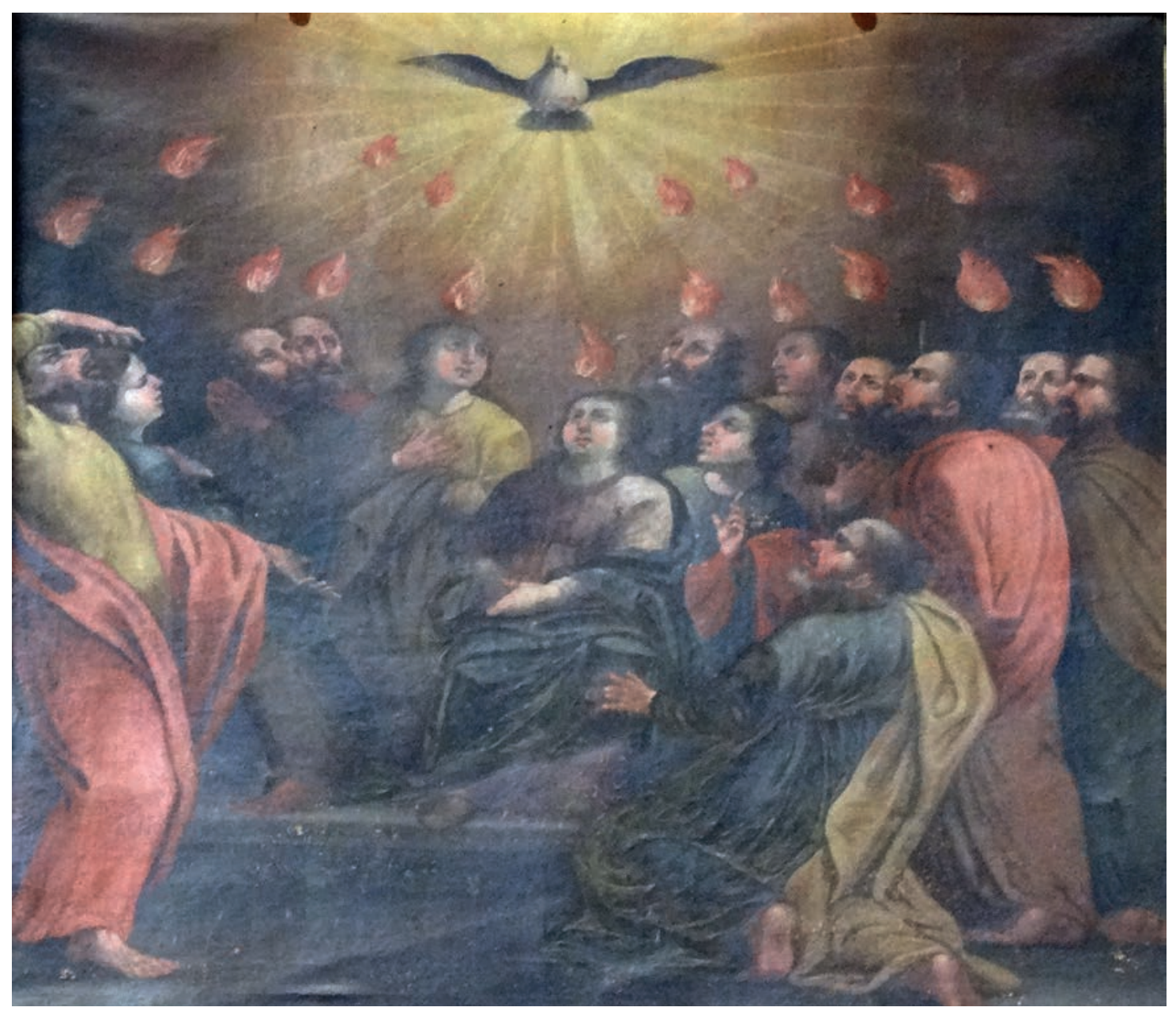

Figura 7.

Pintura de Pentecosta. Joan Oms, 1698.

participar tot l'obrador de manera conjunta i que s'acabà daurant dos anys després (I666). Aquesta tasca va ser duita a terme tant pel fill, Joan Oms Bestard, com per un altre integrant del taller, fins ara desconegut, Joan Baptista $\mathrm{Oms}^{53}$, però, per la importància de la tasca del fill, Joan Oms Bestard, pel que fa a la imatge de Sant Domingo, segons hem vist en la transcripció, aquesta figura sembla que la podem relacionar amb un altre treball d'aquest obrador: fa pocs anys, es va assignar l'autoria d'un retaule de Sant Joan Baptista (Binissalem) a l'escultor Joan Antoni Oms Tomàs ${ }^{54}$. Si bé en la documentació conservada d'aquesta altra empresa de Binissalem no se'n deixà rastre, els fills també hi degueren prendre part acti$\mathrm{va}$, atès que la imatge principal d'aquest altre moble, dedicat al Baptista, presenta clares semblances formals i estilístiques amb la imatge de Sant Domingo que estem tractant (faccions del rostre, barba i disposició), cosa que fa pensar que la intervenció de Joan Oms Bestard, per aquesta altra estàtua, es presentàs de manera força important ${ }^{55}$.
El 1667, aprofitant la bona disposició de la confraria i que la feina anava bé, Joan Antoni Oms obsequià els promotors amb una petita imatge del Roser. L'obsequi era una figura per dur a la bacina d'almoines dels obrers ${ }^{56}$. Aquesta peça sembla que es correspon a la bacina i a l'estatueta de la Mare de Déu del Roser, que es traslladà del convent i que és conservada a la sagristia de la parròquia (figura 4). Aquest treball no deixa d'ésser una típica figura de taller, en petit format, que representa la Verge Maria aguantant el Nin Jesús. Ha estat repintada diverses vegades a causa de l'ús habitual per a les recol-leccions que feia l'obreria.

Una vegada finat l'escultor Joan Antoni Oms Tomàs, els fills seguiren amb l'obra en la qual, de totes maneres, ja hem vist que havien participat en bona mesura. Els primers anys, la direcció recau sobre el personatge inèdit que ja hem mencionat, Joan Baptista Oms, perquè en els comptes és aquest qui és citat com a escultor en els rebuts de la fàbrica. No sabem si estem parlant d'una altra persona o del mateix Joan Oms Bestard que coneixem del taller i que també es 


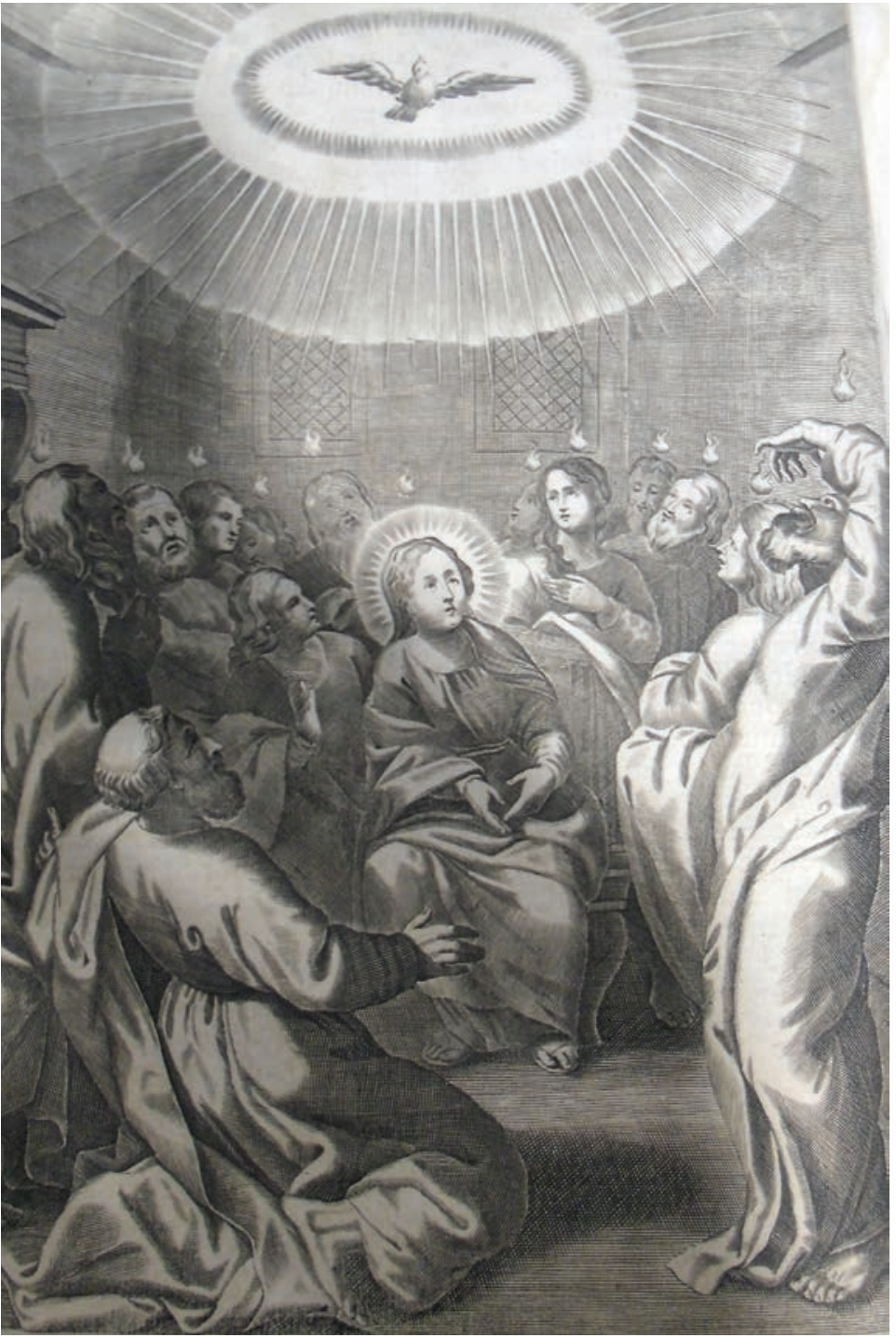

Figura 8.

Gravat de Pentecosta. Breviari. Segle XVII.

troba mesclat en els registres. Per tant, abans de recaure la direcció de l'obrador en el fill Gaspar, s'hauria pogut produir aquest moment de traspàs. L'obra principal registrada a nom de Joan Baptista Oms pot ser relacionada, directament, amb l'acabament de diverses peces del retaule, com ara la pastera, les polseres laterals del segon i del darrer pis ${ }^{57}$ i l'àtic. L'escultor Joan Baptista Oms fou registrat des de l'any I 669 fins al I $674^{58}$. En tot cas, l'obra i la part més important durant aquesta intervenció és l'acabament del retaule i la construcció de l'àtic que el corona, una tasca que coneixem explícitament gràcies als rebuts signats per ell. En total, el cost d'aquesta zona escultòrica sumà més de 200 lliures mallorquines ${ }^{59}$.

L'àtic del retaule presenta algunes diferències respecte de tot l'ordenament anterior. El fons es treballà en policromia cel enfront de la resta del moble, que es daurà. Aquest to pogué ser l'indicat perquè es tractava del color marià, que, al cap i a la fi, corresponia a la titular del moble. A diferència dels pisos inferiors, les quatre columnes que formen l'àtic no són anellades i comencen amb una base bulbosa - un tret que també era típic de l'obrador coetani dels Pinya - i van seguides d'una decoració arquitectònica fugint de la vegetal o figurativa que preval a la columnària del cos del moble. $\mathrm{A}$ més a més, és l'única zona del retaule on s'han conservat les polseres treballades en baix relleu amb un àngel orant a cada costat.

Un Joan Oms, pocs anys després (I682), rebia to lliures a compte per fer dos àngels ${ }^{60}$. Una única partida que fa de mal destriar si es refereix als àngels de mig relleu de l'àtic o, una vegada arribat a estar conformat el moble, aquestes peces es podrien tractar dels dos àngels que se situaren damunt la cornisa del segon pis. No se n'han conservat més dades específiques, però bé és possible que siguin aquestes dues figures, perquè la resta d'àngels del retaule, inclosos els dos de la polsera de l'àtic, no deixen d'ésser escultura decorativa que no solia ser citada de manera explícita en els registres comptables. Les dues figures són dos dels tres arcàngels celestials. A la dreta, hi veim, possiblement, l'arcàngel sant Rafel, qui, encara que hagi perdut els atributs, sembla que conservi el pot amb la substància que curà els ulls de Tobies i, a l'esquerra, l'arcàngel sant Miquel amb la cuirassa de soldat i la disposició de clavar la llança (no conservada) a la figura del dimoni encadenat davall dels peus. De totes maneres, com hem vist, en el treball d'aquestes figures, hi degueren participar els diversos germans. Formalment, podem observar que la figura de sant Miquel és molt més estilitzada i fina, amb una cabellera caiguda damunt l'esquena, mentre que l'arcàngel sant Rafel, a banda de ser una imatge més robusta i plena, presenta menys moviment. A més, el cap, la cabellera i el cos són més plens i ovalats.

L'any I684, l'obra escultòrica es trobava en gran part acabada i es procedí a daurar-la a partir del bancal ${ }^{61}$. En aquest cas, tornam a trobar un escultor citat amb el nom de Joan Antoni Oms, que no pot ser el fill de Gaspar Oms, perquè només té cinc anys. Suposam, per tant, que és Joan Antoni Oms Arbona, nat el I 663, fill de Joan Oms Bestard i Joana Arbona Amengual. Durant aquests anys, és localitzat en les tasques d'acabament del retaule major de Sant Domingo, a Ciutat, amb treballs a l'església de Santa Creu i també en el retaule del Puig d'aquesta mateixa vila de Pollença (I689-1690)62. Aquest és l'escultor que agafà el protagonisme $i$, en certa manera, la direcció de l'obra amb la dauradura de la pastera i la fabricació del sagrari. Els primers anys de la dècada de 1680 , es començà 


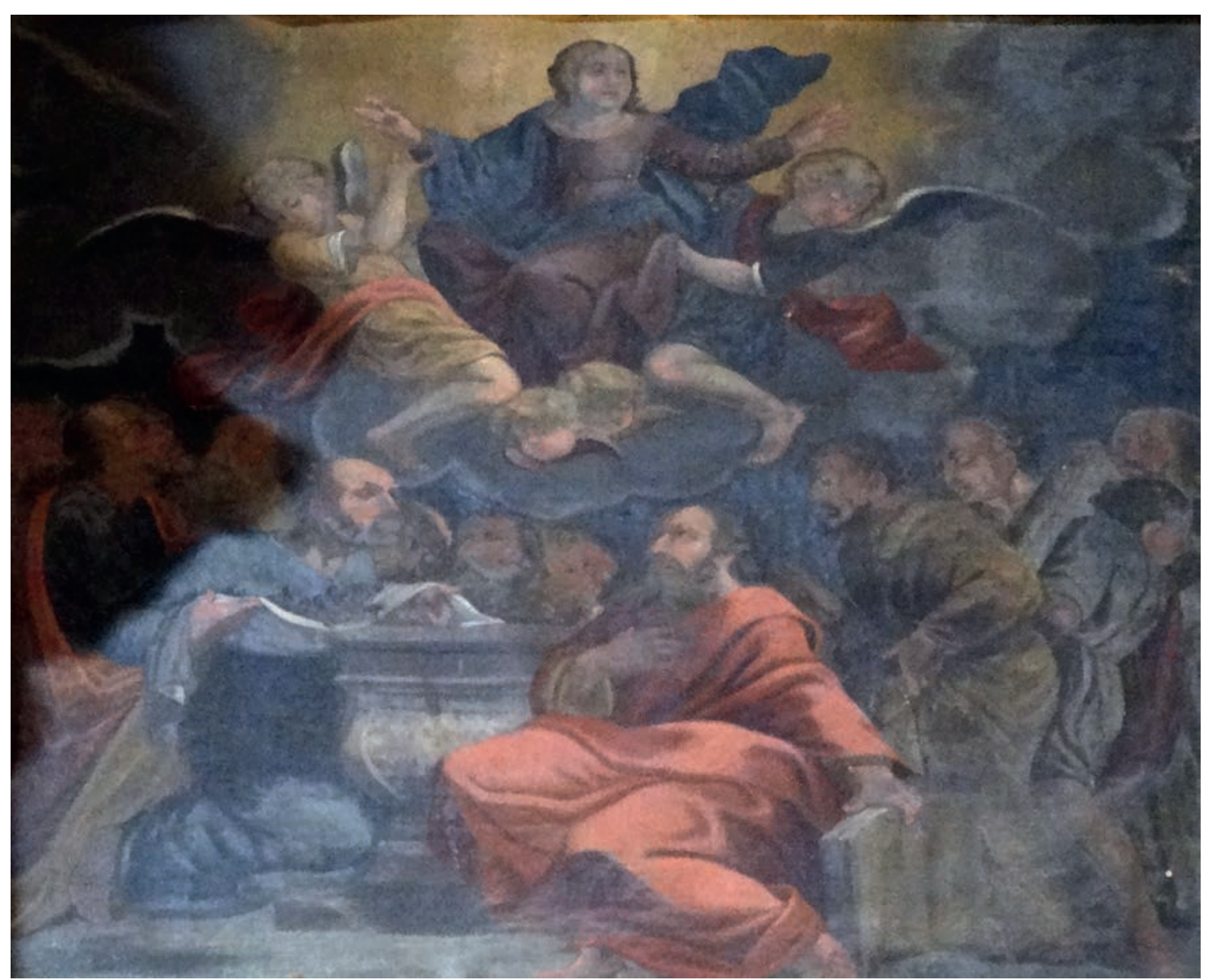

Figura 9.

Pintura de l'Assumpció de la Verge. Joan Oms, 1698.

a daurar i a donar color al bancal i, a la segona meitat, es va iniciar la fabricació del sagrari.

La tasca de construcció del sagrari, així com el daurat, s'allargà quasi deu anys (de r688 a 1697). En base als rebuts conservats, es pot dir que aquesta nova peça correspon quasi totalment a Joan Antoni Oms Arbona, si bé també hi trobam participant, de manera secundària, Gaspar Oms i Rafel Torres ${ }^{63}$. El sagrari es va acabar el I695 i aquest any es començà amb el daurat a càrrec dels altres escultors que hem anomenat. Pel que $\mathrm{fa}$ al nou escultor que hi apareix, Rafel Torres, serà qui seguirà l'obra del retaule en els anys posteriors, una vegada el taller dels Oms hi deixi de fer feina ${ }^{64}$. Com veurem, les pintures del sagrari, igual que les altres del conjunt del retaule, foren encarregades a Joan Oms Arbona, l'altre germà de l'escultor que aleshores intervenia en el sagrari i de qui parlarem més endavant. El I697, aquest pintor s'encarregà de fer-hi les tres pintures dels costats per poc més de sis lliures, quan gairebé ja era enllestit el daurat de la peça ${ }^{65}$.

El sagrari, realitzat també com a expositor, així com les pintures, s'ha conservat en el carrer central del moble. N'ocupa la predel-la i arriba fins al nínxol de la Verge del Roser (figura 5). La peça, a la part baixa, fou treballada amb dos estípits amb un cap d'amoret $\mathrm{i}$ coronat amb un timpà trencat. En els dos extrems, hi ha dues volutes acabades en dos poms. A la part del damunt, hi trobam l'expositor, de majors dimensions, alçat fins a l'altura del primer pis del retaule sobre un basament ovalat. L'expositor s'acaba amb un baldaquí rebaixat. L'ús del baldaquí era un tret difós, en aquella època, pels treballs de l'oncle d'aquest escultor, Gaspar Oms Bestard ${ }^{66}$. El cos principal de la peça es distribueix en tres carrers separats per columnes salomòniques. Les pintures de Joan Oms Arbona omplen aquesta zona. Aquest sagrari de Pollença recorda, per la profusió de la decoració a la base, així com per l'ús de les columnes salomòniques i la volta superior, el que també realitzà Joan Antoni Oms Arbona i el seu germà, Gaspar, per al monestir de Santa Margalida, ara conservat a la parroquial d'Esporles.

La pintura central de l'expositor representa la rebuda de la Comunió per la Verge. La Verge és acompanyada per dos nins àngels vestits d'es- 


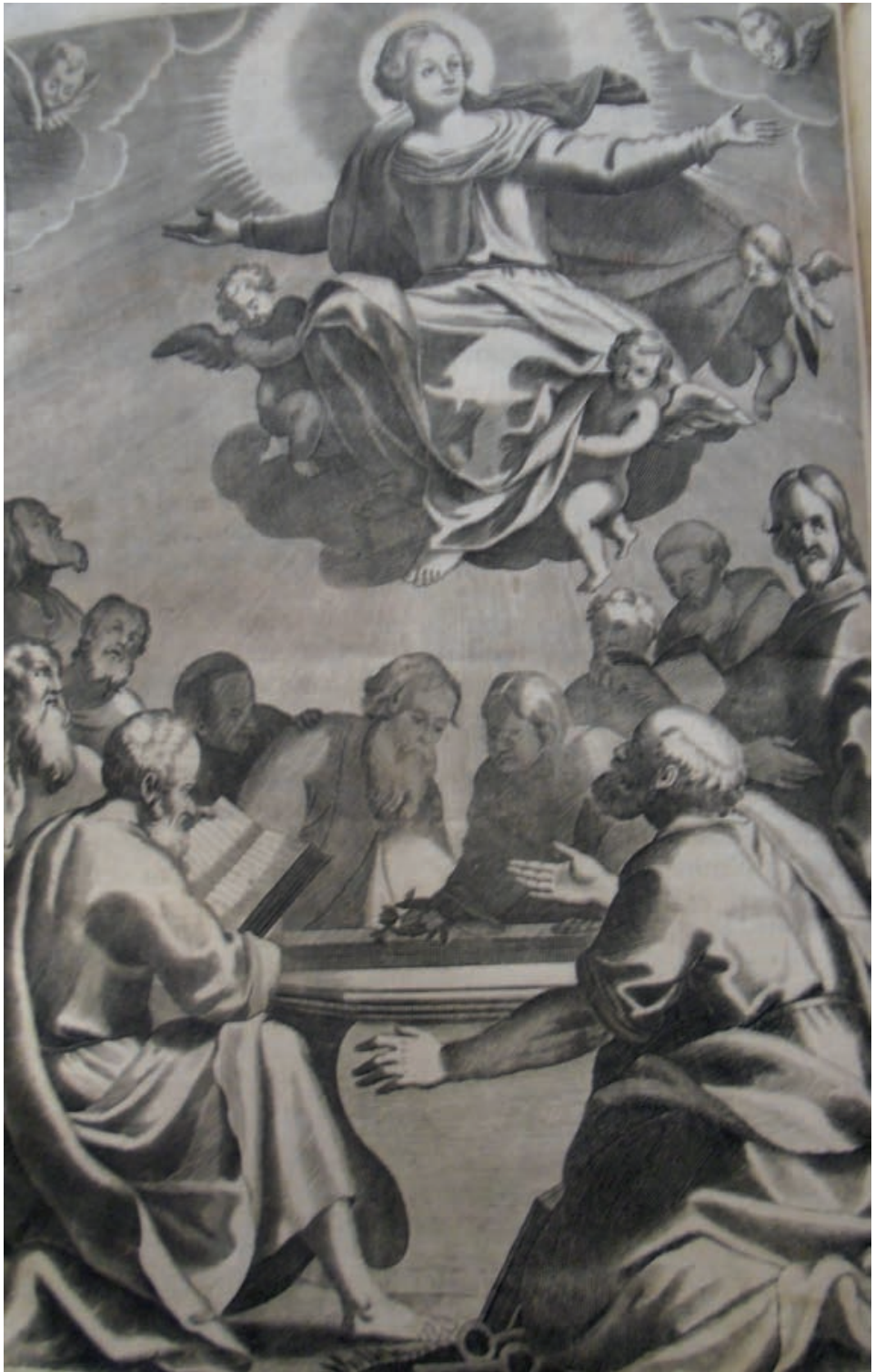

Figura 10.

Gravat de l'Assumpció de la Verge. Breviari. Segle XVII.

colans aguantant un ciri encès. Part damunt de l'escena, s'obri una Glòria amb l'Esperit Sant. Aquesta iconografia de la Comunió de la Mare de Déu la trobam representada a uns altres llocs de Mallorca, sobretot en centres conventuals. Per exemple, en una pintura anònima del monestir de Santa Magdalena i una altra en el monestir de Santa Clara de Ciutat de Mallorca. D'altra banda, el Museu Diocesà de Mallorca també en guarda una altra. Aquesta darrera, comparada amb la de Santa Clara, són dues representacions pràcticament copiades. L'escena entra dins les narracions pietoses i descriu la comunió de Maria administrada per Sant Joan ${ }^{67}$. Les altres dues pintures dels costats, segons la inscripció que s'hi pot llegir, són dos sants dominics: a l'esquerra, sant Pius V vestit de pontifical amb els braços oberts mirant el cel. Pius V, durant aquella època, era un papa que estava en ple procés de difusió, perquè havia estat beatificat el 1672 i fou canonitzat el I7 I 2. La pintura de la dreta és sant Joan màrtir i es deu referir al dominic Joan de Colònia, víctima, en el segle XVI, dels conflictes amb els calvinistes. Fou beatificat el 1675, però no acabà canonitzat fins l'any i 867 .

Una vegada acabat quasi tot el treball escultòric, excepte el daurat $\mathrm{i}$ algunes intervencions menors, o el cambril, que encara haurà d'esperar algunes dècades, el convent optà per fer una nova figura del Roser destinada a ser portada en processó.

L'any I 700, un Gaspar Oms cobrà 25 lliures per la feina d'una figura de la Mare de Déu del Roser amb el tabernacle corresponent. Així, el convent podia disposar d'una estàtua creada a posta per a les processons ${ }^{68}$. Aquesta imatge deu ser la que ara es conserva a la sagristia parroquial (figura 6). El tabernacle, si bé no l'hem pogut localitzar, consta que també perdura en algun magatzem. Una peça que, pel fet d'estar registrada juntament amb el treball de l'escultor, podem suposar que inclogué una labor escultòrica de certa envergadura.

La nova peça mariana es fabricà damunt una peanya que simulava un núvol, decorada amb caps d'amorets i acompanyada, a cada costat, per un nin àngel orant. La figura del Roser aguanta el Nin Jesús a la mà esquerra, mentre que, amb l'altra mà, que es troba una mica avançada, devia sostenir el collar del rosari, un element iconogràfic que no se n'ha conservat. La talla es realitzà amb un vestit d'abundants plecs verticals que segueixen l'eix ondulat de la figura. A la banda del darrere, un mantell blau cel alçat pels costats contribueix a accentuar l'efecte de moviment que ofereix la figura. La corona que es fabricà per a tal ocasió potser és la que encara conserva.

No creiem que aquest treball escultòric correspongui a les darreres peces que obrà l'escultor Gaspar Oms Bestard, perquè morí dos anys després. Gaspar Oms Bestard (1638-1702), l'escultor que treballava amb el seu pare i amb els seus germans a les primeres dècades de la construcció del retaule del Roser, té poca obra coneguda: dos retaules, el de la Pietat, de l'església de Santa Eulàlia, i el del Sant Crist, del monestir de Sant Jeroni a Ciutat, juntament amb l'atribució d'algun altre treball per al convent de Santa Clara $^{69}$. No sembla que aquesta peça (àgil i plena de moviment, que fuig de molta imatgeria estàtica de les dècades anteriors) fos una de les darreres que va fer, sinó que correspondria a una obra de Gaspar Oms Arbona (I668-1745), el germà de Joan Antoni Oms Arbona que ara hem vist que treballava en aquest lloc. El mateix aire 


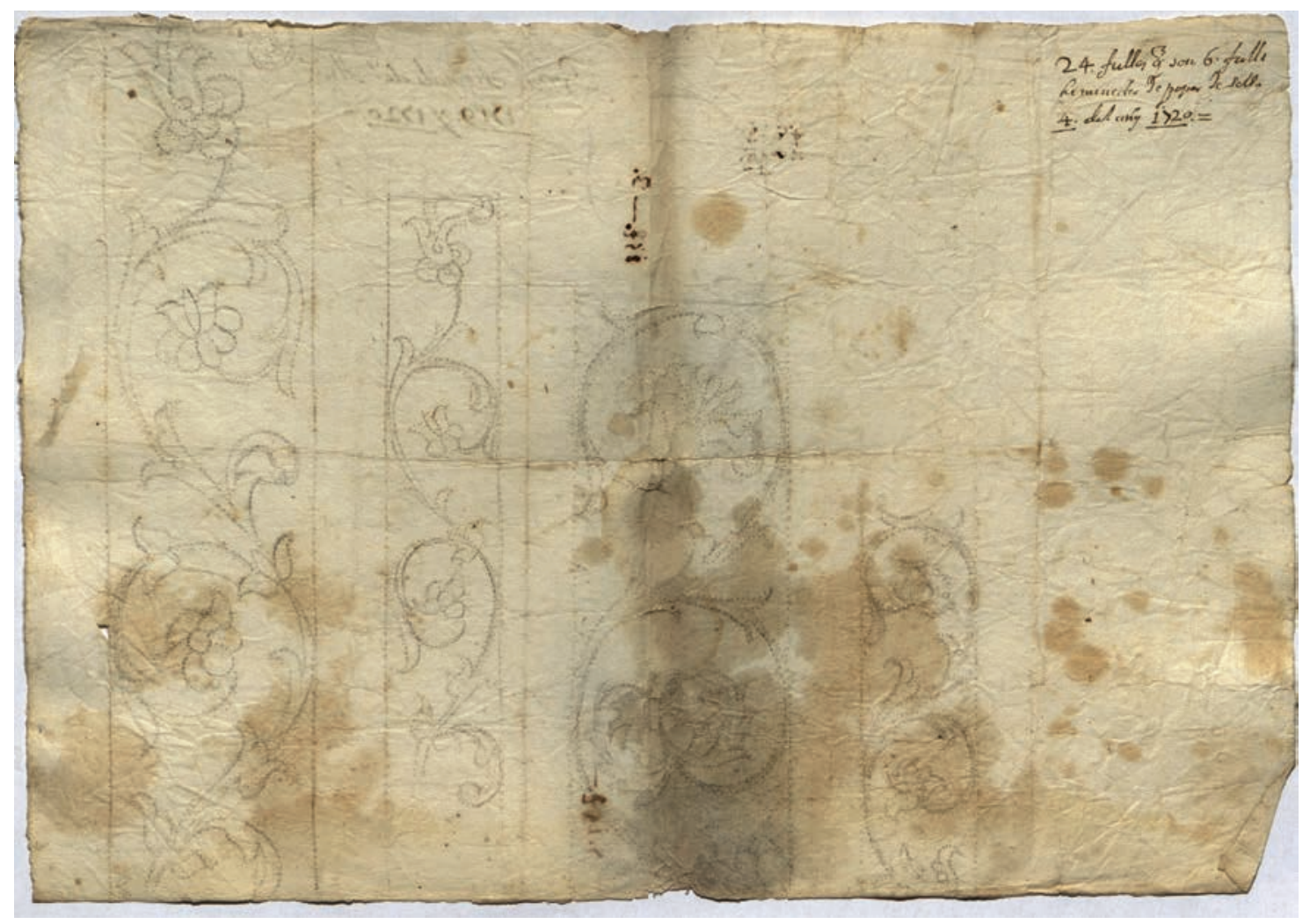

Figura 11.

Plantilla de calc. Cercle dels Torres, 1720.

i moviment d'aquesta figura el podem trobar en alguna altra del retaule major que hem mencionat d'Esporles. Ara bé, cal dir que, si bé el retaule d'Esporles és una obra d'aquest taller, no podem afirmar el mateix de les figures que conserva, ja que, pel que sembla, quasi la totalitat de les imatges que tenia es perderen. L'única peça que ofereix certa garantia és la figura de santa Isabel, que es troba en el segon pis del carrer de la dreta ${ }^{70}$. Efectivament, en aquest cas, el tractament del rostre i l'estil, no pas el moviment, sembla que té relació amb l'exemple de Pollença.

\section{Les pintures dels quinze misteris del Roser, de Joan Oms Arbona}

L'any següent que Joan Oms pintàs les pintures del sagrari, ell mateix s'encarregà de tot el programa pictòric dels misteris del Roser d'aquest retaule.

El pintor Joan Oms Arbona (1663-1733) era, com hem dit, el germà dels escultors que, durant aquella època, estaven treballant per als dominics. El pintor s'examinà en el gremi d'artistes de l'illa l'any r $696 \mathrm{i}$, per tant, es pot dir que aquestes obres foren de les primeres de la seva carrera artística. Aquest pintor va realitzar unes altres tasques en un retaule, ara desaparegut, de l'ermita de Valldemossa, i poca cosa més se'n sap ${ }^{71}$.
El juliol de i698, Joan Oms Arbona començà a cobrar per les pintures dels carrers laterals del retaule. L'artista elaborà els quinze misteris del Roser, que, al cap i a la fi, no representaven cap originalitat en el seu programa iconogràfic, atès que és la temàtica pròpia d'aquesta advocació. Dedicà la segona meitat de l'any I 698 a crear les pintures i a colllocar-les, i acabà la tasca el mes de desembre ${ }^{72}$.

Com hem dit al començament, els dominics, a més d'introduir la devoció del Nom de Jesús, en tenien una altra de més integrada i extensa, com era la del Roser. A Ciutat de Mallorca, així com a Pollença, ja hi havia confraries dedicades al Roser abans de I 500 . Hem de pensar que, a Pollença, una vegada instal-lat l'orde dominicà, i abans de crear el convent actual, l'orde fou adscrit a l'oratori del Roser, que ja es trobava en aquest poble. Una vegada mudada la comunitat al nou convent, els frares s'hi endugueren el retaule original d'aquesta capella primitiva. La imatge que conserva el retaule actual potser és la que recolliren del vell oratori. El transport del moble va fer que l'oratori l'hagués de substituir per un altre de nou ${ }^{73}$.

Aquesta devoció i el programa iconogràfic que l'acompanyava era una meditació de l'evangeli mitjançant quinze episodis de la vida de Maria: cinc episodis de dolor, cinc de goig i 


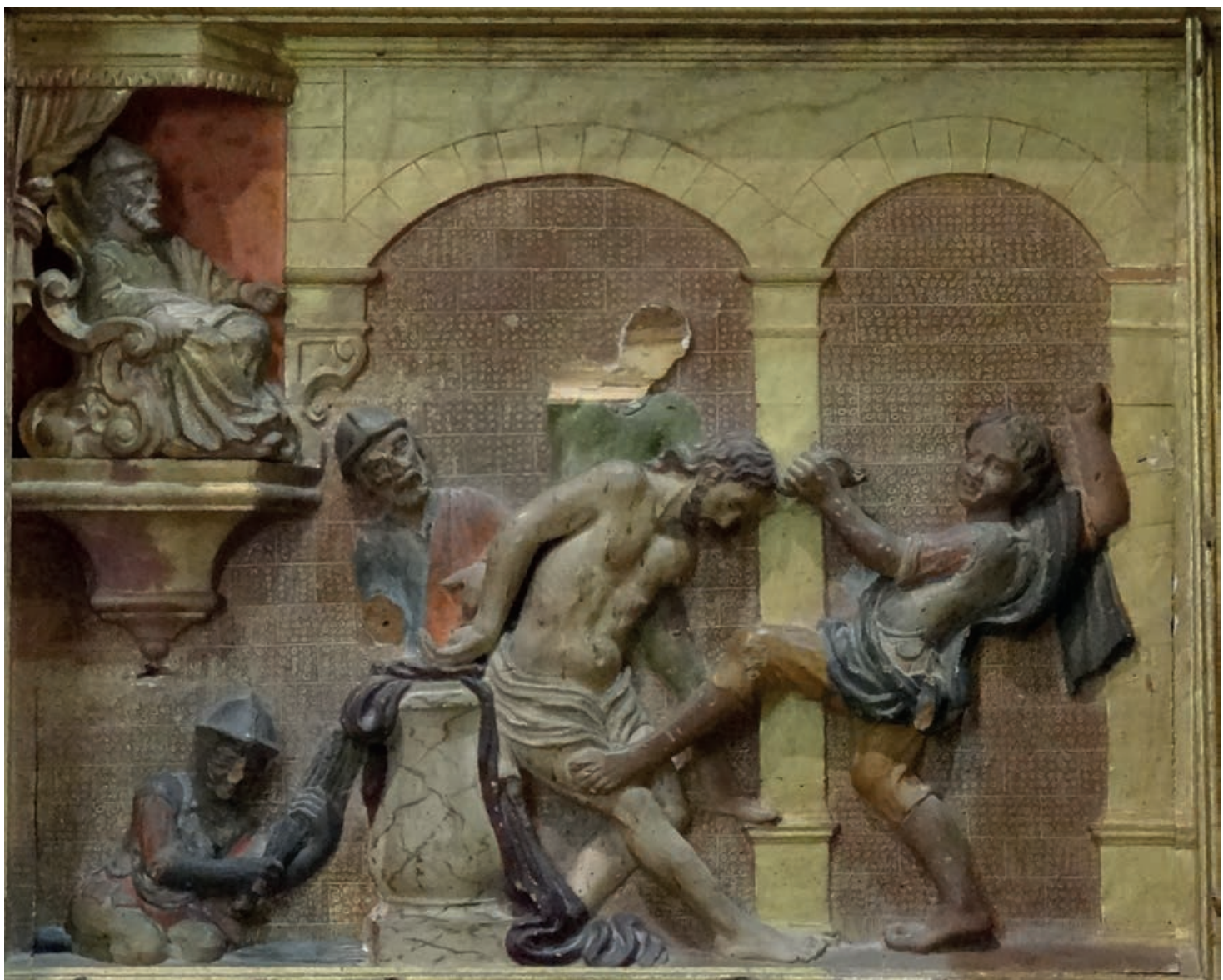

Figura 12.

Relleu de la Flagel-lació. Rafel Torres, 1727. Convent dels dominics. Pollença.

cinc de glòria ${ }^{74}$. A Mallorca, hi trobam algunes de les primeres representacions d'aquest tipus amb les obres que s'han conservat del taller pictòric dels López de la segona meitat del segle $\mathrm{XVI}^{75}$. En tot cas, els programes iconogràfics del Roser que es desenvolupaven a Mallorca dins d'aquesta època, a la qual hem d'inscriure el de Pollença, entren dins el marc de la reforma catòlica i dins la segona expansió que tengué el Rosari ${ }^{76}$.

Les pintures s'han conservades en els carrers laterals del retaule juntament amb la de l'àtic. En total, tretze peces de les quinze que realitzà. Les dues de la predel-la foren substituïdes, pocs anys després, per dos baixos relleus fets per l'escultor Rafel Torres.

L'ordre de les pintures la trobam en seqüència cronològica segons els episodis bíblics a què fan referència. El cicle del Roser comença amb la sèrie dedicada als goigs amb la primera pintura del cim del carrer lateral de l'esquerra i segueix amb les pintures que baixen pel carrer: l'Anunciació amb Maria i l'arcàngel Gabriel. La sèrie continua amb la Visita de Maria a Santa Anna i els episodis de tres escenes de la infància de
Jesús: el Naixement, la Presentació en el Temple i Jesús Nin davant els mestres. Després, hi trobam les pintures dedicades, amb els dos relleus, als episodis de Dolor i Passió: l'Oració a l'Hort amb l'aparició d'un àngel amb els atributs de la Passió, la Flagel-lació, l'escena de l'eccehomo i les darreres dues pintures, que són la Pujada al Calvari i la Crucifixió, que ja estan disposades a la part baixa del carrer dret. Finalment, tanquen el cicle dels misteris els cinc episodis de Glòria: la Resurrecció de Crist, l'Ascensió, la Pentecosta, l'Assumpció de Maria i, finalment, en un format major, la pintura del cim del retaule, que tanca el programa dels misteris dedicat a la coronació de la Verge.

Les pintures segueixen una tonalitat colorista amb una execució correcta en l'espai i en la conformació de la composició dels grups de figures, encara que aquestes es troben realitzades amb un volum inflat i gairebé estàtiques. La tècnica és bastant limitada per la composició dels contorns $\mathrm{i}$ en alguns casos presenten alguna desproporció. Els models que utilitzà el pintor són els propis de l'època, que se solien basar en gravats coetanis. Els exemples 


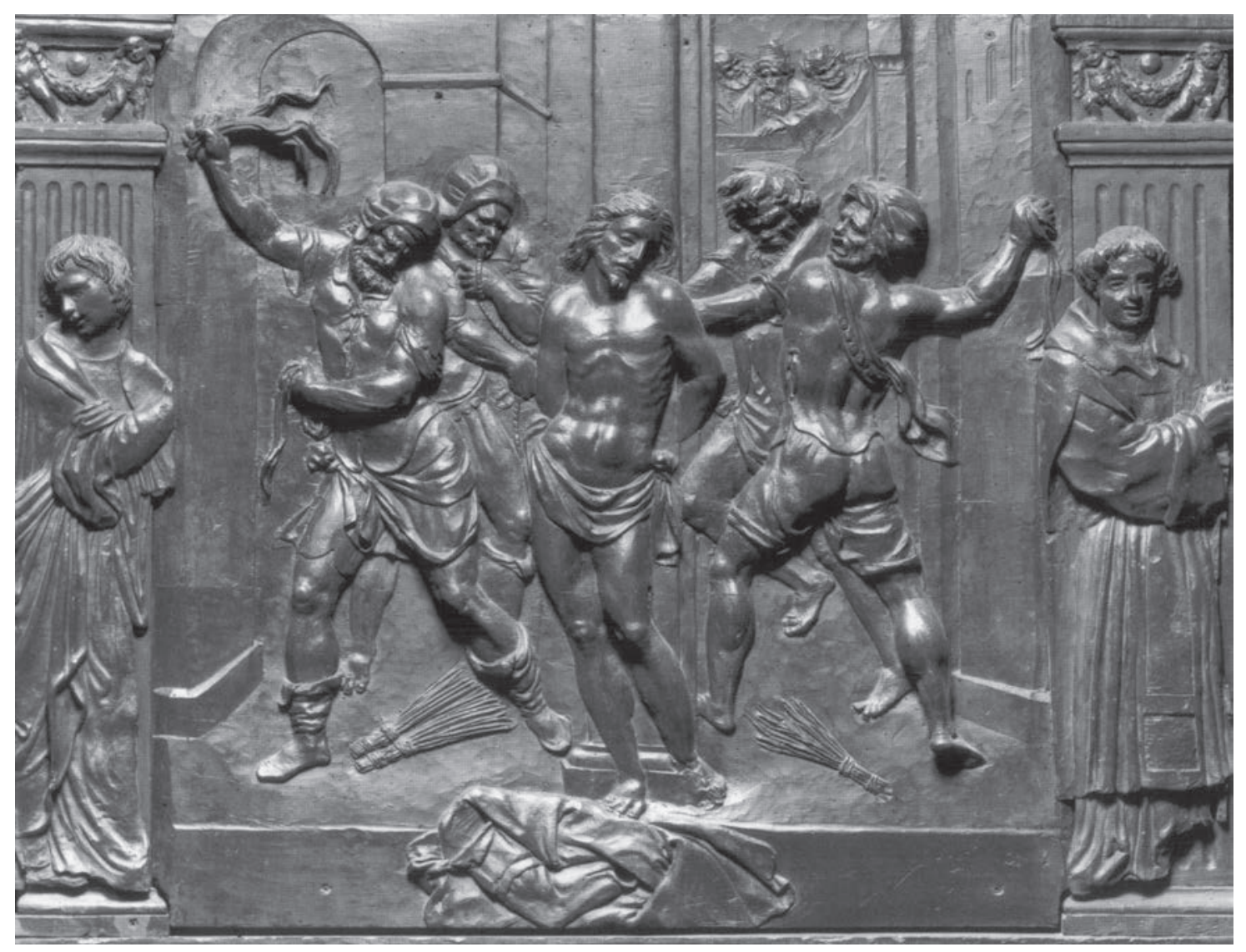

Figura 13.

Relleu de la Flagel-lació. Segle XVII. Púlpit de la Passió. Basílica de Sant Llorenç. Florència. Fotografia: Alinari, 1852.

que circulaven més, a través d'estampes, durant aquests anys, solien ser obres d'Albrecht Dürer, Cornelius Cort, Sadeler i Wierix, entre d'altres ${ }^{77}$. Emperò, cal dir que la majoria d'escenes no surten del context habitual i comú que també trobam estampat en la majoria d'edicions bibliogràfiques de caràcter litúrgic, unes edicions bibliogràfiques d'ús habitual dins les sagristies conventuals i parroquials de l'època. Les estampes que representen la Pentecosta (figura 8) i l'Assumpció de Maria (figura ro) d'un breviari del segle XVII (ca. I63I) que es troba dipositat a l'Arxiu Parroquial de Llucmajor ${ }^{78}$, per exemple, ofereixen el model que copià el pintor Oms a les obres que reprodueixen aquest tema del retaule dominic (figures 7 i 9). L'escena de Pentecosta situà la Verge asseguda en el centre amb les mans baixes $i$ en esquema triangular. A darrere, Santa Magdalena amb les mans plegades sobre el pit i la resta de deixebles. A un costat de la Verge, un deixeble agenollat alça la mà i, a primera línia, dos deixebles més són realitzats amb moviments extrems: un està dret i contorsionat amb els braços que introdueixen tot el grup i, a l'altra banda, una figura, potser de sant Pere, agenollada amb els braços oberts i amb el cos forçat endarrere. El mateix exemple copiat en totes dues tècniques (pictòrica i estampada) el trobam a l'Assumpció de Maria, si bé mostra lleugeres diferències, no pel que fa a la composició, sinó a la formació dels personatges. La Verge central, representada amb els braços oberts i el mantell volat, és aguantada per diversos àngels infantils en el gravat $i$, més adults, en la pintura. A baix, el sepulcre de caire circular és enrevoltat pels deixebles; a l'esquerra, el deixeble que té un llibre és substituiit per una tela a la pintura i, a la dreta, el deixeble ha voltat cap a l'espectador aguantant el llibre a terra. A la banda dreta del gravat, hi ha un curiós deixeble, aillat de l'escena, que mira l'espectador i que ha estat eliminat en la versió pictòrica.

Que aquestes composicions eren bastant conegudes no només ho demostren els parallelismes que hem vist entre la versió pictòrica i la gràfica d'un breviari, sinó que també ho podem comprovar en la mateixa pintura de l'Assumpció, perquè, uns quants anys després, s'usà aquesta mateixa composició per a realitzar la pintura central del retaule homònim de la parròquia d'aquesta vila. 


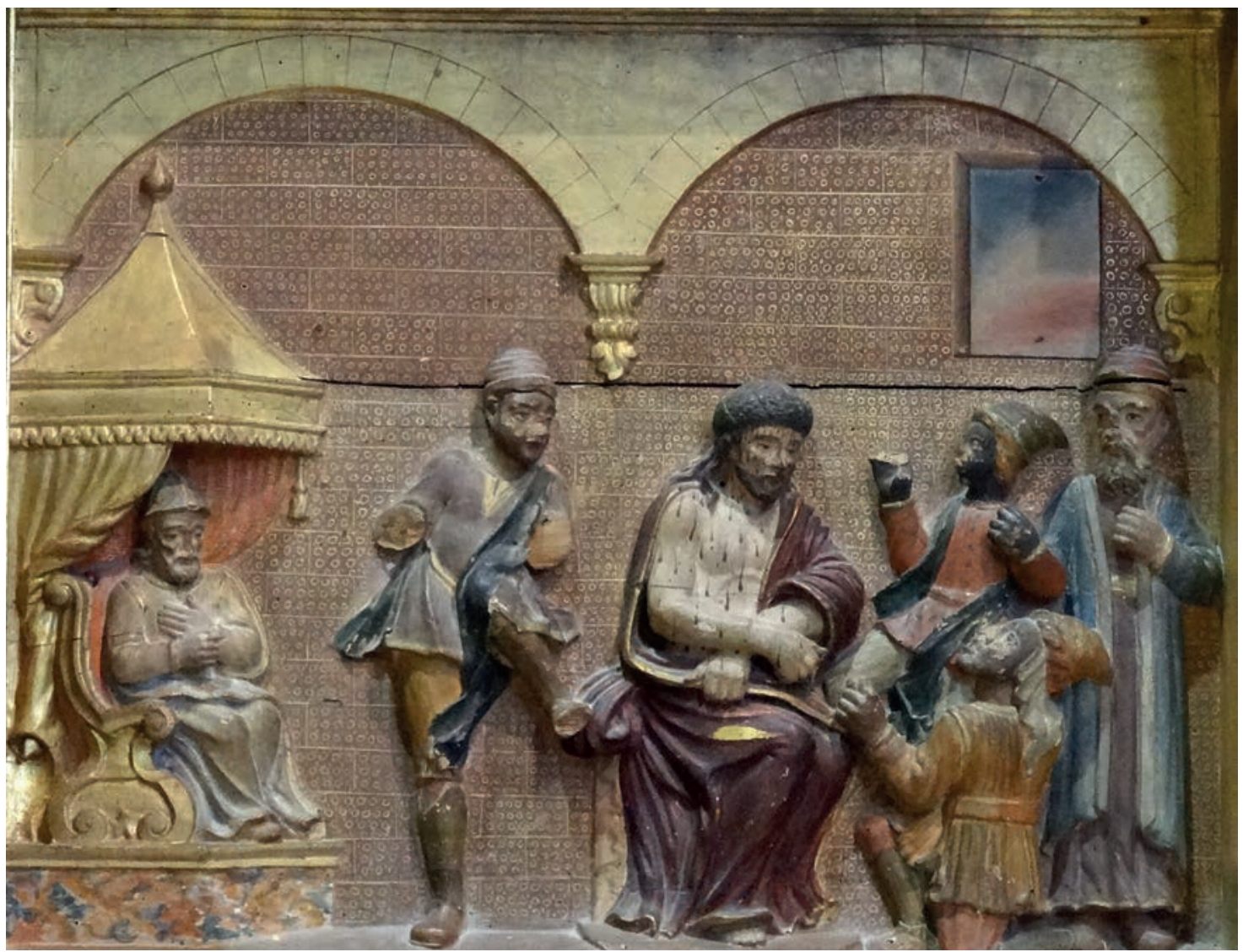

Figura 14.

Relleu de la Coronació d'Espines. Rafel Torres, 1727. Convent dels dominics. Pollença.

\section{L'escultura en baix relleu de Rafel Torres Palerm}

L'escultor Torres, que ja ens ha començat a aparèixer un poc abans dins els treballs d'aquest retaule, segueix essent un artista amb poca obra coneguda. Rafel Torres Palerm (I675-1752) era fill del més reconegut Gabriel Torres Cladera (I637-1709) ${ }^{79}$ i de la seva primera muller, Joana Palerm Llobera. Gabriel aconseguí acumular un bon patrimoni familiar en vida. El fill Rafel seguí l'ofici familiar i es casà dues vegades, tengué diversos fills i, de la tasca professional, se'n coneixen alguns treballs menors a Manacor i, potser, una altra feina realitzada a l'església de sa Pobla i a la de Sant Miquel de Ciutat. A Pollença, a més dels dos relleus que seguidament desenvoluparem, va realitzar un Sant Magí per al Puig ${ }^{80}$. Així com hem localitzat l'escultor Joan Antoni Oms en tasques de taxació, l'escultor Rafel Torres també realitzà, el I75 I, tasques de peritatge, amb altres pintors i escultors, per a algunes figures lul-lianes ${ }^{81}$. El pare era bastant reconegut a nivell de gestió de negocis, com també per la seva petjada artística, una mostra de la qual és una de les obres més originals i de magna fàbrica amb l'enteixinat que realitzà per al voladís de Cort a Ciutat ${ }^{82}$. Que Gabriel tenia una bona mà per als negocis es demostra en el fet que enriquí la seva nissaga. D'això n'és testimoni el rastre documental que deixà. Per exemple: el 1679 , trobam l'escultor Gabriel firmant un document notarial amb Baltasar Morei de Sencelles i pare del convent de Sant Domingo de Ciutat ${ }^{83}$; l'any i 699, firmava el que sembla ser una altra acta de caràcter mercantil ${ }^{84} \mathrm{i}$ el mateix any collocava en matrimoni la filla Maria que havia tengut amb Elisabet Banys, la seva segona muller, amb Pere Joan Valens ${ }^{85}$; el 1705 , podem trobar-lo en uns altres documents en què apareixen l'escultor Gabriel Torres i la parròquia de Sant Miquel de Palma en relació amb unes celebracions i amb unes amortitzacions al Reial Patrimoni, com també amb la confraria de la Verge Maria del convent de Sant Francesc de Ciutat $^{86}$. El tràmit patrimonial més important d'aquesta nissaga el localitzam el setembre de I725, quan apareixen els hereus de l'escultor Gabriel Torres amb la família Monjo, potser sobre gestions pendents de l'escultor ${ }^{87}$. D'altra banda, seguim trobant Rafel Torres Palerm l'any I 710 fent de testimoni en un document notarial del fuster Bartomeu Marimon ${ }^{88}$, i el I723 feia, una altra vegada, de testimoni a Pere 


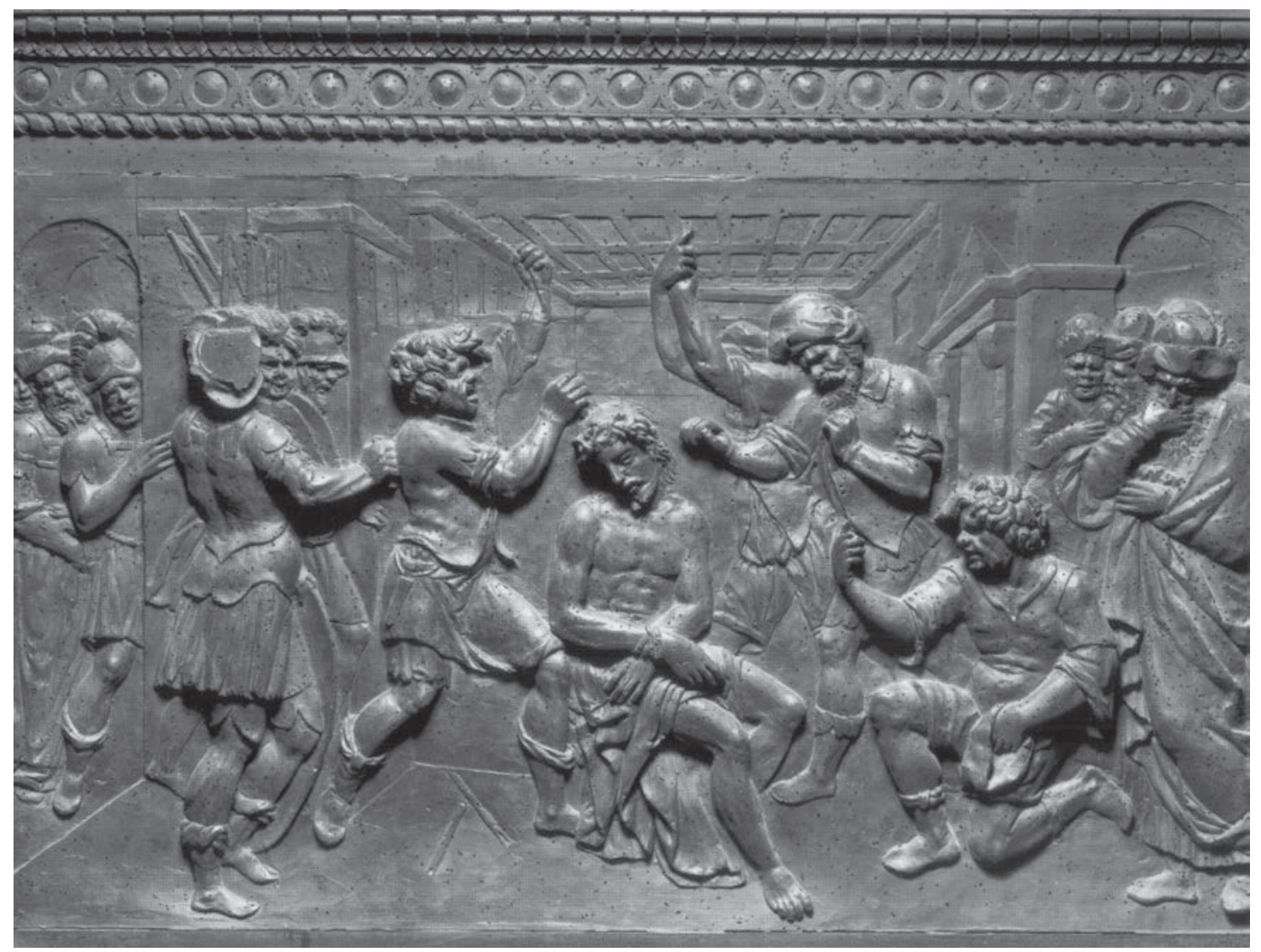

Figura 15

Relleu de la Coronació d’Espines. Segle XVII. Púlpit de la Passió. Basílica de Sant Llorenç. Florència. Fotografia: Alinari, 1852.

Coll, un clergue beneficiat de la parròquia de Sant Miquel, per a les darreres voluntats ${ }^{89}$.

Entre aquest cercle de l'obrador escultòric dels Torres, s'ha conservat, entre la documentació d'un notari coetani - el notari Sitjar-, uns dissenys de plantilles de calc amb diversos models de sanefes decoratives de caire vegetal. Podrien ser exemples de mostres per a ser aplicades en esgrafiats, talla de fusta, policromia o estofat dins els acabats de les peces escultòriques que es feien llavors (figura II). En el fragment conservat (ca. 1720), hi apareixen dos models de sanefa de dues mides, on s'observa que foren elaborades en llapis i després punxats els contorns per poder traspassar la marca del disseny, segons exigeix aquesta tècnica artística. Aquestes creacions de sanefa, encara que ofereixen la peculiaritat de poder ser restes d'algun taller de l'època que tractam, no ens donen gaire informació nova pel disseny que s'hi representa. Aquestes creacions eren models molt coneguts dins el món artístic mallorquí i d'ampli recorregut. La coneguda impremta Guasp de Mallorca disposava d'aquest disseny aplicat en planxes xilogràfiques i les trobam mimètiques, o amb lleugeres modificacions, a la collecció que conservava i registrades entre els números de catàleg $\mathrm{I} 482 \mathrm{a} I 488^{90}$.
L'escultor Rafel Torres Palerm començà a treballar en el daurat del retaule del Roser del convent dominic els primers anys del segle XVIII, quan es va fer càrrec de l'empresa. D'aquesta manera, el podem trobar com un dels continuadors de la feina elaborada per l'obrador dels Oms. Ja entrat en certa manera en les despeses, no menors, del daurat, podem veure com, el 1707 , es compraven 3.000 pans d'or i Torres cobrava per posar-los. En resum, durant aquell any, l'escultor posà uns 3.730 pans d'or, una quantitat, de totes maneres, que no serví per acabar-lo i que, una vegada retornat a la localitat, a principis de 1708 , augmentà la tasca posant-ne 2.000 més. Els treballs es van fer en diversos períodes en què també participarien alguns mossos i, algun cop, el fill ${ }^{19}$. La tasca del daurat s'amplià durant els anys següents ( 1709 , I 710 , I7I I, etc.) amb diversos milenars de pans d'or que completarien la superfície del moble. Finalment, en referència a la feina del daurat, se'n localitza una darrera citació el I 2 de novembre de I717: «[...] pagat a Rafel Torres esculptor 2211.9 s. 8 d. A compliment de xexanta 11. que li haviem quedat devent la confraria de tota la feyna ha fet a nel quadro lo dia present $[\ldots] »$, labor que, segurament, no fou la darrera 


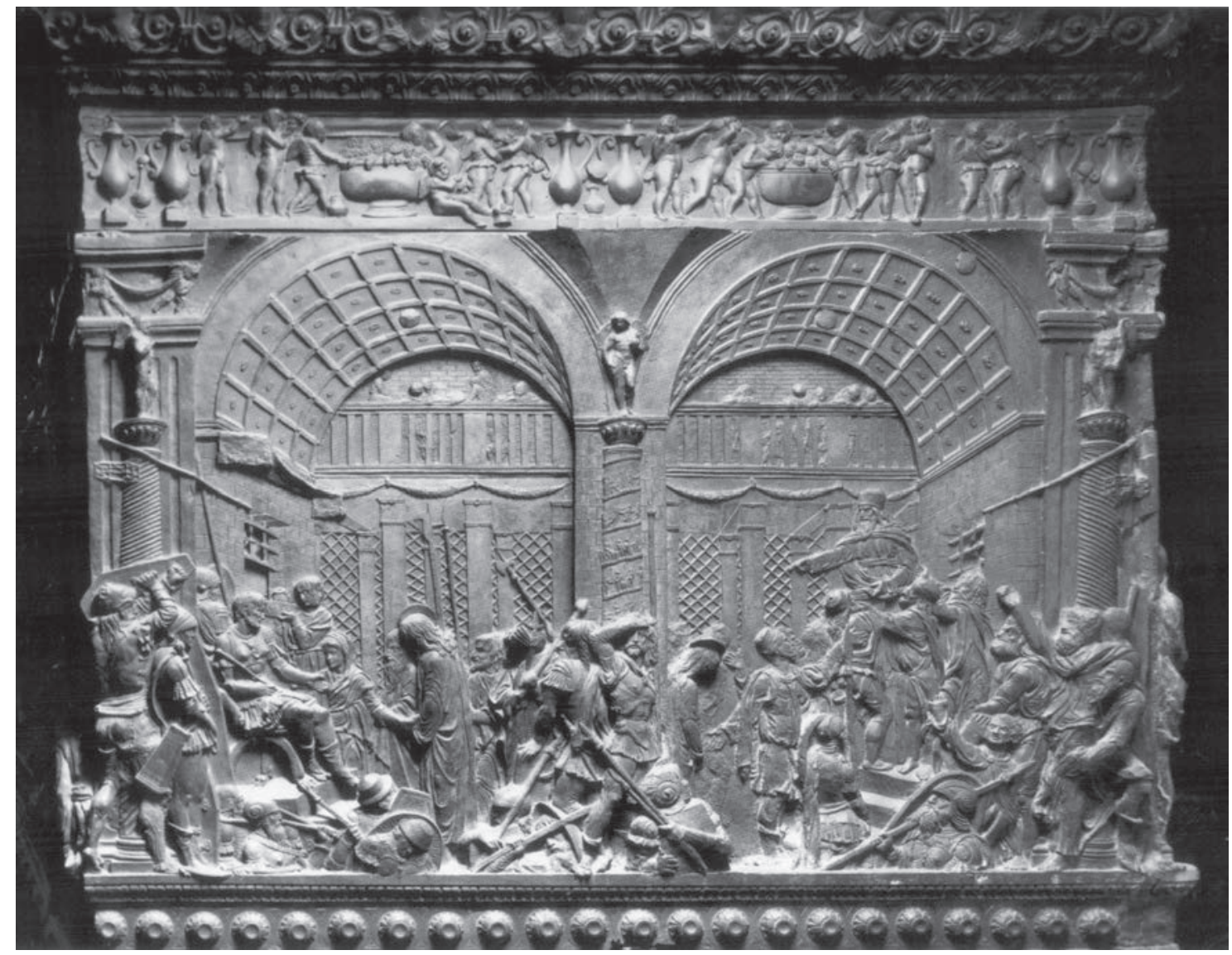

Figura 16.

Relleu de Crist davant de Pilat i Caifas. Segle XV. Púlpit de la Passió. Basílica de Sant Llorenç. Florència. Fotografia: Alinari, 1852.

vegada que realitzà ${ }^{92}$. De totes maneres, podem suposar que la feina del daurat també devia incloure operacions d'acabament, petits detalls, alguna decoració, etc.

Si bé el procés del daurat i el cost que això suposava constituïen una bona font d'ingressos per als escultors i, a la vegada, unes despeses no gens menyspreables per al promotor, aquesta vegada, el treball més interessant que ens ofereix Rafel Torres es troba a les dues peces en baix relleu de la predel-la i que es dedicaren al turment de Crist (figures ${ }_{2} 2$ i I 4 ).

La construcció d'aquests dos relleus no es produí fins l'any 1727 , quan l'escultor cobrà unes primeres is lliures: «[...] quinze lliures a bon conte dels plans de mitx relleu ha fets per el retaule de dita confraria». La tasca el tengué ocupat tres mesos, de l'abril fins al juny de 1727 , a més d'encarregar-se de continuar o d'acabar els costats del sagrari que havia realitzat Joan Antoni Oms Arbona tres dècades abans ${ }^{93}$. Pocs anys després, es compraren unes sacres que, de totes maneres, foren substituides per unes altres d'Andreu Carbonell, i el picapedrer de Binissalem, Andreu Moya, estava duent a terme la feina d'obra de l'altar amb l'aportació del pedreny, el guix i les balustres ${ }^{94}$.
Els dos relleus que Torres realitzà són dos dels episodis de la sèrie del dolor del cicle dels misteris del Roser. En el relleu de l'esquerra (figura I2), hi trobam una escena de la Passió. Crist es troba fermat a una columna quan és assotat i torturat per tres soldats. El de la dreta l'agafa pels cabells, mentre que, amb l'altre braç, té l'assot alçat i el colpeja amb la bota o amb el peu. Les dues figures del darrere són treballades en un relleu molt lleuger per provocar la impressió de profunditat. El soldat del centre ha perdut el cap, però es veu que li pega amb el peu, mentre que el personatge del darrere amb casc devia tenir un altre assot. A l'esquerre, s'hi afegí un altre soldat preparant un fardell. A l'extrem superior esquerre, s'hi troba el setial amb Ponç Pilat damunt penya i cobricel. El fons es treballà amb un mur que s'obria amb dos arcs damunt pilastres.

Al relleu del carrer de la dreta (figura I4), és on trobam l'escena de l'eccehomo, una narració que sembla aquí mesclada amb el de la Coronació d'Espines. Crist, tapat amb el mantell porpra, és acompanyat per un conjunt de tres personatges que li fan befa: l'un està agenollat $\mathrm{i}$ els altres dos es troben situats als costats i l'escridassen. A cada banda, hi ha les dues figures que representen els dos poders, el polític i el 
religiós, de llavors. A l'esquerra, aquesta vegada al mateix nivell i integrada dins l'escena, s'hi tornà a posar la figura de Ponç Pilat $i$, a la dreta, el sacerdot Caifàs. El fons de l'escena, en aquest cas, té un mur cegat amb una finestra oberta i és tancat per dos arcs rebaixats a dalt.

La circulació d'imatges, com en el cas que hem vist de les pintures, era habitual, però, aquesta vegada, a més dels diversos gravats que podien representar aquestes escenes, ens sembla interessant comparar-les amb unes altres, també realitzades en baix relleu, $i$ que es feren unes quantes dècades abans. Els paral-lelismes a què ens referim els trobam amb dos exemples situats en els púlpits de la basílica de Sant Llorenç, a Florència. En concret, amb una escena de bronze del taller de Donatello, on es representa Crist davant de Pilat i Caifàs (figura I6) i dues més, que foren esculpides damunt fusta, amb posterioritat, durant el segle XVII: la Flagel-lació (figura I3) i la Coronació d'Espines (figura I 5 ).

Deixant de banda la diferència abismal pel que fa a la qualitat artística entre les representacions italianes i les mallorquines, ens interessa comparar les representacions dins l'espai arquitectònic i la composició grupal que semblen seguir. Les tres escenes florentines, juntament amb les dues de Pollença, ens ofereixen parallelismes clars de composició i de fons. Una de les semblances que hi són paleses és que combinen l'ús i la composició de murs, pilastres i obertures amb el mateix gust. Vegeu el gran arc de triomf de dues voltes que es presenta en el relleu de Crist davant de Pilat i Caifàs, que el trobam simplificat a la nostra escena de l'eccehomo. Les figures de Pilat i Caifàs també són a cada costat. La barreja de les escenes sembla que es produeixen al relleu de l'eccehomo del convent pollencí agafant l'escena florentina de la Coronació d'Espines amb alguns trets i elements del relleu en bronze de Crist davant Pilat i Caifàs. D’altra banda, a la Flagel-lació de Pollença, hi ha la confusió d'elements i dels personatges dels dos relleus del segle XVII del púlpit florentí, on s'uneixen trets de les escenes de la Coronació d'Espines amb la imatge de la Flagelllació.

Vegeu també com, pel que fa a la possible ascendència italiana de les obres mallorquines, en trobam l'exemple gràfic en un gravat dedicat a la Flagel-lació realitzat pel gravador Aegidius Sadeler II. El gravat segueix una composició del pintor Giuseppe Cesari ( I 568-I640), un pintor romà conegut amb el nom de Cavaliere d'Arpino. L'obra comparteix la composició, les disposicions de les figures $i$ el fons d'arcades i era una peça coneguda dins l'àmbit peninsular, perquè se'n troben còpies realitzades en tinta i plomín ${ }^{95}$. A més, podem trobar a l'illa les versions pictòriques deixades pel català Joaquim Juncosa

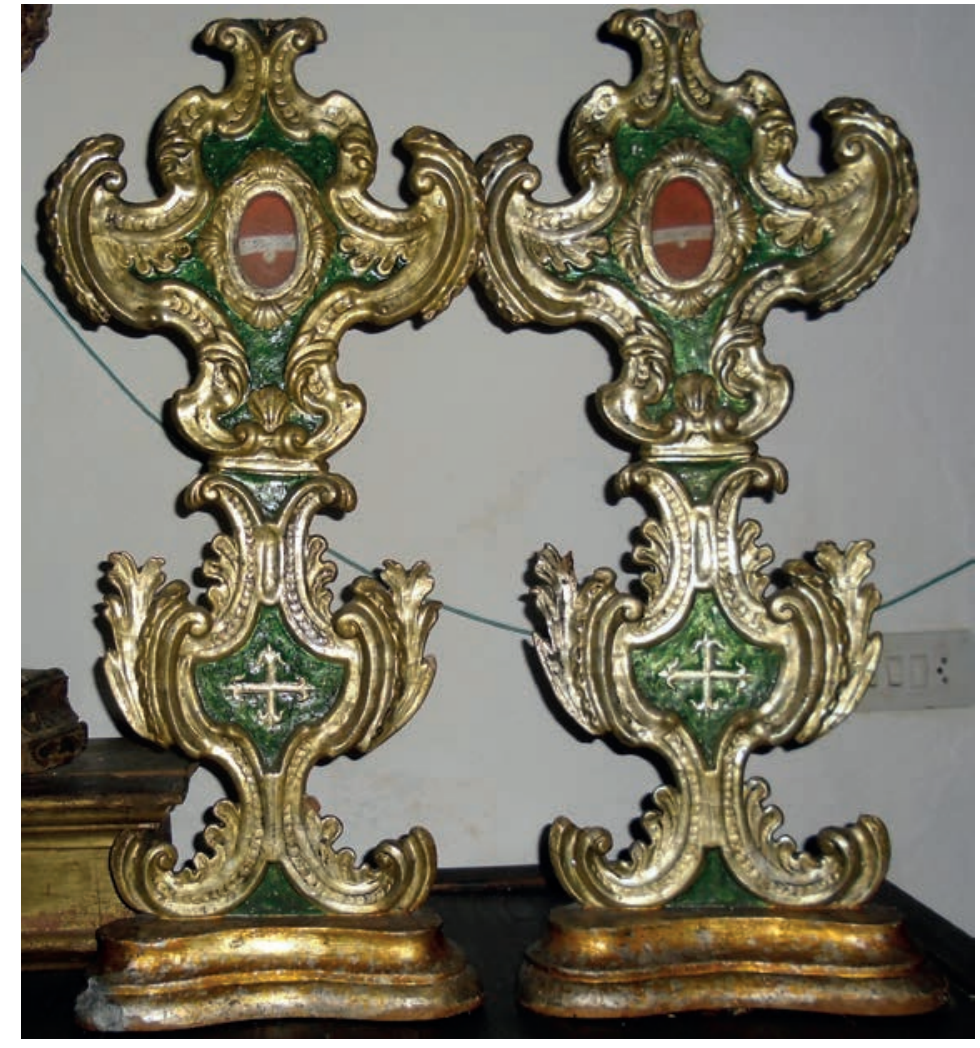

Figura 17.

Reliquiaris del Convent del Roser. Andreu Carbonell, 1759. Sagristia parroquial de Pollença.

a la Cartoixa de Valldemossa (c. I678-I684), un altre pintor amb influències de la península italiana, on, a més, també s'hi havia desplaçat.

No podem comprovar si existeix cap influència directa d'aquestes obres entre els dos centres, però, en època moderna, hi havia una bona comunicació entre Mallorca i la península Italiana. En altres casos, basta observar com, en els registres documentals, i observats de manera aleatòria, hi consta que la presència italiana era habitual en els documents notarials. A tall d'exemple, ho podem veure en els casos de Jaume Xapre i Geroni Scambix, mariner, tots dos de Gènova i domiciliats a Mallorca, els quals, el desembre de 1682, havien de partir cap a la ciutat d'Aliorne. L'any següent, un mallorquí anomenat Josep Suau era nomenat procurador per poder actuar a la ciutat de Nàpols, i Baptista Belloto, un noble de l'illa, en aquell temps, vivia a Nàpols. També trobam personatges genovesos residents a Mallorca, per exemple: Catalina Grafuli o el mariner Isidro Costa, de Sant Olari de Nervi, de la ribera genovesa ${ }^{96}$. El I690, localitzam Joan Huxell, del poble d'Utri (Gènova) i, el I696, el mariner Josep Rey, natural dels Estats Pontificis, que estava domiciliat a Mallorca i que feia una procura general a la muller, Magdalena Torres, que es trobava absent. Un dels testimonis d'aquest document va ser un altre genovès, 


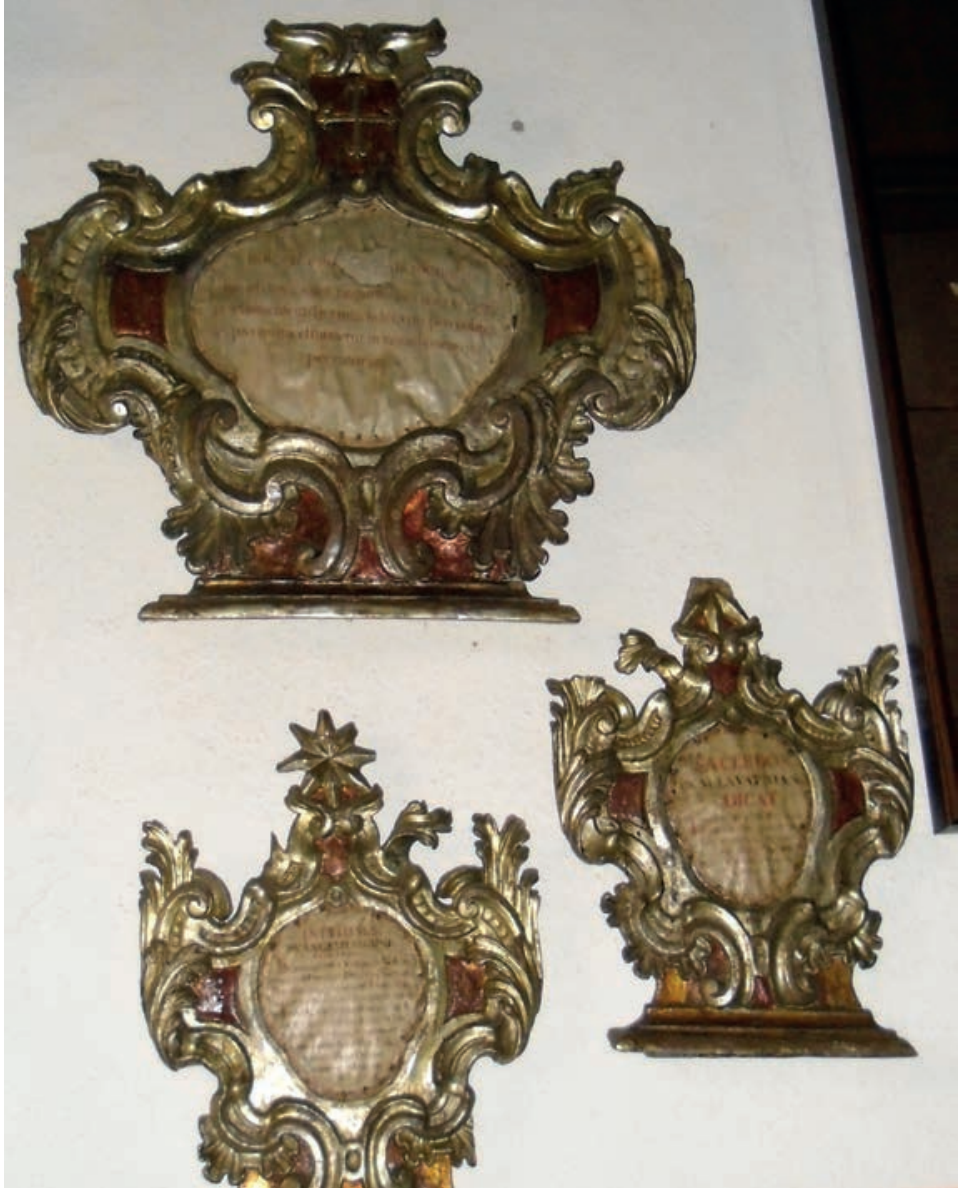

Figura 18.

Sacres del Convent del Roser. Andreu Carbonell, 1759. Sagristia parroquial de Pollença.

el pintor Jacinto Leó ${ }^{97}$. El I694, el clergue Guillem Mesquida, fill de mercaders, partia cap a Roma i feia procurador el seu pare, Francesc, i el germà Joan Antoni, també clergue. Tota una altra família italiana, els Frontixelli, igualment genovesa, estava domiciliada a Mallorca durant la segona dècada del segle XVIII ${ }^{98}$, $\mathrm{i}$ almenys un dels seus membres, Carles Frontixelli, tenia contactes amb l'escultor Miquel Cantallops, perquè trobam l'escultor fent de testimoni per un deute que tenia Francesc Amer amb l'italià (I724) ${ }^{99}$. A més, no era l'escultor Cantallops l'únic artífex mallorquí amb contactes, almenys mercantils, amb el món italià, perquè Joan Sagarra, el primer escultor que hem vist treballant per al convent dominic de Pollença, habitava una casa a Palma, per la qual pagava un censal a Joan Baptista Campeggio, un clergue de Bolonya que havia estat bisbe de Mallorca (I532-I 558$)^{100}$.

D'altra banda, és ben sabuda la nòmina d'artistes de l'illa que viatjaren a Itàlia i que reberen formació. Sense voluntat de fer-ne cap llista exhaustiva, podem citar alguns dels que han estat més estudiats, com ara Miquel Pont, Guillem Mesquida o Onofre Cotto. Aquest darrer, a més, era d'una nissaga d'origen italià ${ }^{101}$. També podem mencionar alguns artistes italians que passaren a residir a l'illa: els milanesos Parrino, Giuseppe Dardamone o, fins i tot, l'escultor Herrera, un madrileny d'ascendència navarresa que hi arribà després d'una estada a Roma ${ }^{102}$.

Per tant, l'escultor Rafel Torres Palerm pogué conèixer aquestes obres florentines directament, a través de viatges, per altres peces o en reproduccions gràfiques.

\section{El cambril de l'escultor Andreu Carbonell}

El nou escultor que faria obra a Pollença fou Andreu Carbonell. El treball que se li va assignar va ser realitzar l'interior del cambril de la figura del Roser. Va ser durant la dècada de I740 quan aquest escultor se n'encarregà de la nova fase, tant en referència a l'escultura com al daurat. Carbonell es reuní de manera explícita amb la comunitat dominica per contractar el cambril de la Verge. La nova obra se subscrigué per un cost de $\mathrm{I} 30$ lliures $i$, gràcies al contracte que n'ha perdurat, en podem veure l'acord al qual s'arribà:

Vuy el pr juliol de 1742 trobantse en est Convent Nstra Sra. Del Roser de la present Villa de Pollença, Me. Andreu Carbonell esculptor de la Ciutat, convingue dit Carbonell ab el M.R.P. Sr. Fr. Guillem Reynes, Prior de dit convent y ab el P. Fr. Domingo Sureda Rector de la Confraria de dita Nsra Sra. Y en presencia de tota la comunitat de dit convent, de fer y treballar el camaril del altar mayor devant la figura de Maria Ssa ab lo modo y forma que se manifesta ab la trassa que nos ha manifestat que es ad instar del camaril que el dit Carbonell feu a la capella del Roser del Convent de St Vicenç de Manacor, y tot el preu, tant de llenyam que se haura mester per dit camaril, com per el treball de la escultura et alias (menos lo daurar) va per dent trenta lliures dich I 30 ll. las quals se obliga y contenta lo dit Carbonell de cobrar de la confr. De dita Nstra. Sra. De la dita present Vila, de lo que fructificarà dita Confr a mes de los gastos presios de la mateixa: I per ser la veritat fas lo present a requisició de dit M. R.P.Pr y dit Me. Carbonell, los quals firmen de las suas propias mans. Vuy dit dia y any.

Fr. Guillem Reynes, prior.

Fr. Domingo Sureda, rector de dita Confraria.

Andreu Carbonell, esculptor ${ }^{103}$. 
L'escultor Andreu Carbonell (ca. I680-I764) s'havia format amb Gaspar Oms Bestard i, una vegada establert, va muntar un taller al qual s'incorporaria el seu fill pocs anys després. Carbonell era conegut, per tant, dins el cercle dels Oms i no resulta estrany que el trobem seguint la tasca començada per ells. A més, l'escultor Rafel Torres, que hem vist realitzant el daurat i els relleus de la predellla, era un bon company d'aquest altre, perquè el I 749 declarava al seu favor i també participà amb Torres dins el grup de peritatge que hem comentat més amunt (I75I). Carbonell té obra a diversos llocs de l'illa: en un retaule major de Sant Felip Neri, en el retaule major i el de Sant Serapi del convent de la Mercè, a Palma, així com a la població de Banyalbufar, entre d'altres. A més de la fabricació de peces, també actuava com a intermediari en la venda d'obres d'art. En aquest cas, el podem trobar, cap a la segona meitat del segle (1743), fent de mediador per la compra d'un retaule de la Immaculada a les monges del convent de Santa Magdalena de Palma, que adquiriria el clergue Joan Riera per a la població de Petra ${ }^{104}$. El fill homònim només li sobrevisqué quatre anys. Tenia obra establerta a les poblacions de Manacor, Deià, Bunyola o Inca. D’altra banda, també se sap que el taller realitzà treballs de petit format o peces arquitectòniques (claus de volta) per a la parroquial de Petra ${ }^{105}$.

Tal com consta en el contracte que hem vist fet a Pollença, a Manacor, a banda d'alguns treballs a la seva parròquia, tenia relacions laborals amb els dominics d'aquesta localitat i ja els havia realitzat un altre cambril del Roser per al convent, una peça que, de totes maneres, no s'ha conservada. Les remodelacions sofertes a causa de la implantació del neoclàssic a començaments del segle XIX, així com la desamortització, afectaren molts dels mobles d'aquest recinte ${ }^{106}$.

El començament de la feina del cambril la trobam el mateix mes del contracte, en què cobrà 22 lliures i que continuà de manera intermitent fins al I75 I, quan se n'inicià el daurat. En aquests mateixos anys, es deixaren registrades unes altres obres que s'anaren fent dins el convent, si bé sense deixar-ne constància de l'autor: el cancell del portal major, que deu ser el que conserva el temple, i, el 1745, la collocació d'una figura de la Verge amb un ca (símbol de sant Domingo) en el portal major ${ }^{107}$. El cambril i la decoració s'acabà cap al I75 I i, després, Carbonell seguí fent feina amb el daurat i la policromia secundàries ${ }^{108}$.

El cambril (figura 5), a més de conservar-se, ens servirà per fer-nos una idea de l'obra desapareguda que realitzà per al convent de Manacor, en la qual, plàsticament, devia participar en gran mesura. Aquesta peça, a més de la decora-

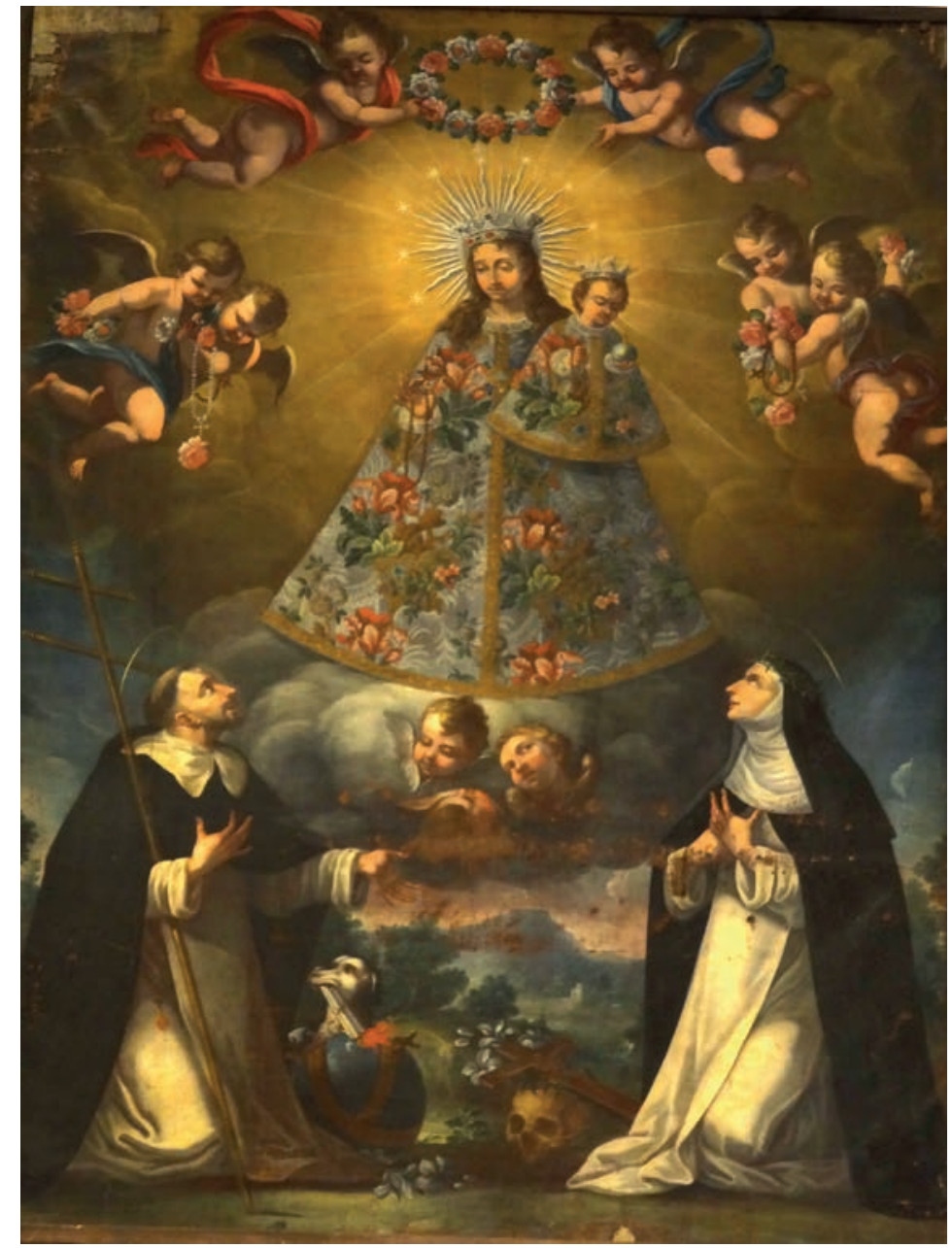

Figura 19.

Pintura de la Mare de Déu del Roser amb sant Domingo i santa Catalina. Esteve Sanxo, 1746. Convent del Roser. Pollença.

ció dels costats i de la part superior a manera de volutes llises en forma vegetal, es formà seguint una estructura pentagonal de cinc costats, tot acabat amb una mitja cúpula gallonada folrada amb caps d'amorets, aparellats o individuals, amb una clau de volta i, a la banda baixa, l'Esperit Sant. En principi, també deuen ser de Carbonell els quatre àngels de cos sencer disposats al voltant de la Verge, dos a nivell de la peanya, de caire adolescent amb una vestimenta moguda i els braços oberts que presenten la figura titular, $i$ dos nins àngels més damunt de la Verge, també amb els braços oberts en eix diagonal. Quant a la tècnica i als acabats, s'hi combinà l'ús del daurat per a la decoració i les pilastres del cambril amb la policromia usada per a les figures.

La feina d'Andreu Carbonell degué agradar a la comunitat dominica, perquè no tengueren cap problema per, pocs anys després, a finals de la dècada de 1750, tornar-li a encarregar uns altres treballs. Aquesta vegada es tractava de peces mòbils i d'ús litúrgic, com ara diverses 


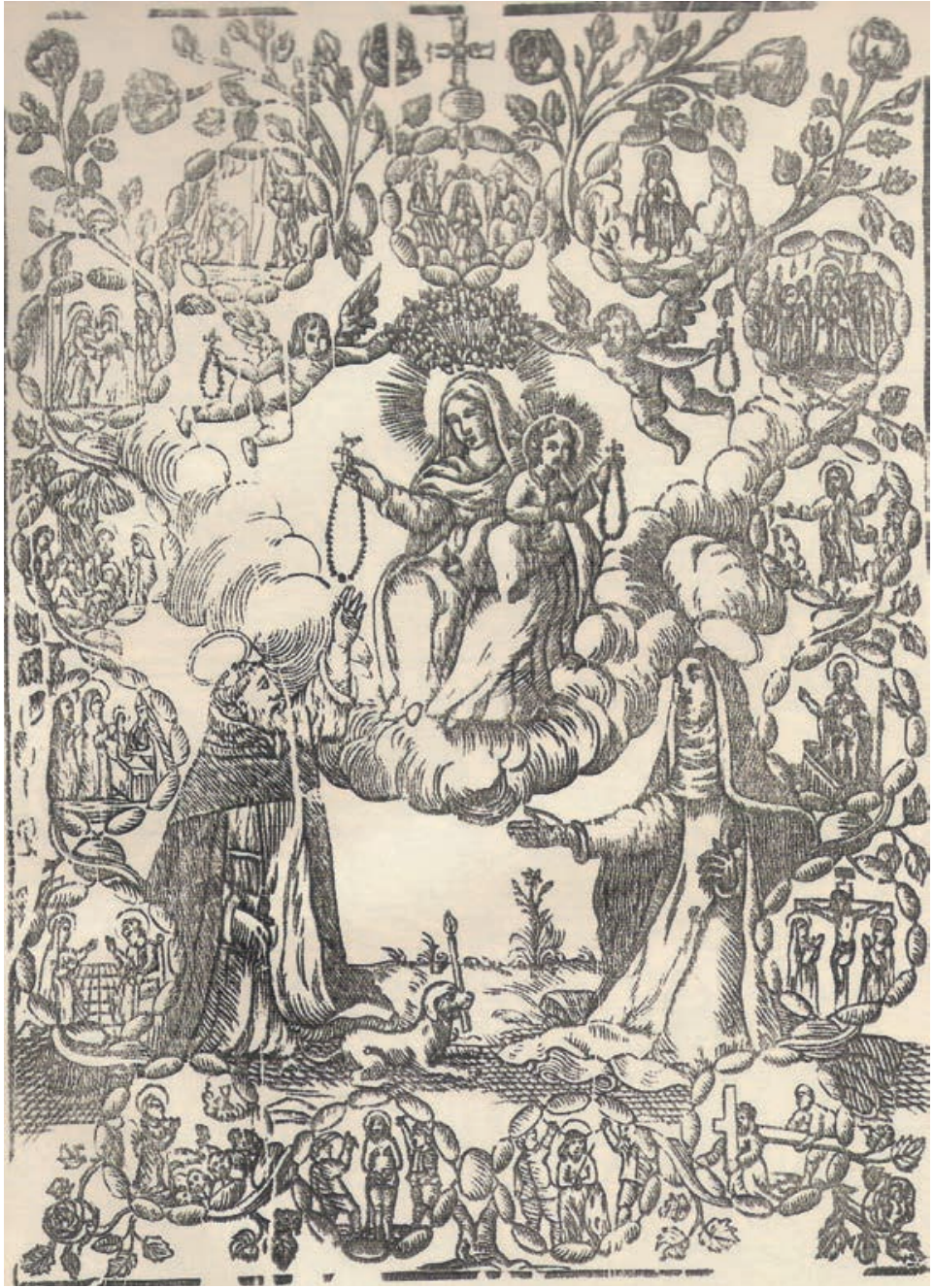

Figura 20.

Xilografia de la Mare de Déu del Roser. Impremta Guasp.

sacres, reliquiaris i canelobres. En total, fabricà sis reliquiaris, sis canelobres $i$ tres sacres, eren uns objectes per a l'altar major que foren també policromats i platejats. L'import pagat va ser de 44 lliures $^{109}$.

Aquestes peces de petit format, com l'estatuària fàcilment transportable que també hem tractat, sembla que passaren al dipòsit de la sagristia parroquial. Es considera que la seva fabricació va ser realitzada de manera conjunta, amb el mateix estil. Si és així, tant per l'estil de les peces com per la quantitat conservada (sis reliquiaris $i$ tres sacres), es corresponen amb els sis reliquiaris de taula juntament amb les tres sacres que estan repartides per sobre de les calaixeres $i$ en els murs laterals d'aquesta sagristia (figures I7 i I 8). Aquests objectes, a més de portar una creu dominica en el centre, que també hem trobat en el llibre de la Confraria del Nom de Jesús que hem citat al començament, tenen els costats platejats amb el fons de la peça pintat de verd en els reliquiaris $i$ de vermell a les sacres.
Alguna sacra ha conservat una estrella en el seu cim, que, potser, es reproduïa a la part alta de les relíquies. Malauradament, aquesta zona els ha estat escapçada. Aquesta estrella era, com sabem, un altre element típic de la iconografia de sant Domingo. Es tracta de la icona que es representava damunt del front del sant $\mathrm{i}$ que servia, a més, com a símbol decoratiu de l'orde $^{110}$.Aquest tipus de reliquiari és un disseny seguit a l'època. Els exemples de Carbonell ofereixen una peça molt treballada, alta i esvelta. En canvi, el temple de Santa Maria la Major (Inca) té almenys dos reliquiaris d'aquest tipus també datats al voltant dels mateixos anys (ca. I748): la relíquia de sant Pere apòstol i la del vel de la Mare de Déu. En proporció, aquests altres exemples baixaren en altura $\mathrm{i}$ això ho supliren augmentant-ne l'amplada ${ }^{111}$.

\section{La pintura de Nostra Senyora del Roser, d'Esteve Sanxo}

Coetàniament a les tasques del cambril de Carbonell, es decidí dotar el nínxol del retaule d'una pintura de Nostra Senyora del Roser. La imatge fou feta el 1746 i servia per tapar la figura del nínxol quan requeria el temps litúrgic. Aquesta vegada, la confraria optà per contractar els serveis del pintor Esteve Sanxo (ca. I700I784). El cost registrat de la feina fou de poc més de 20 lliures $^{112}$. L'artista, que llavors tenia 46 anys, rebia influència de la pintura italiana i s'havia format amb el pintor Miquel Pont, que també circulava dins el corrent italià i al qual ja hem fet referència quan hem tractat les peces de Rafel Torres. No era la primera vegada que Esteve Sanxo treballava per a aquest orde, perquè el I722 ja havia pintat per a la capella del Roser dels dominics de Ciutat. A més, a Pollença, si ja no havia obrat algunes peces, es pot dir que, a través d'aquests frares, aconseguí ser conegut per la clientela local. Pocs anys després, va treballar la decoració de l'església dels jesuites d'aquest poble (1752-1764) amb l'escultor Pere Joan Obrador. També trobem unes altres obres de Sanxo escampades per diversos indrets de l'illa: Felanitx, Caimari, Llucmajor o Palma, entre d'altres ${ }^{113}$.

El quadre que realitzà per tapar el cambril de la Verge s'ha conservat damunt del portal lateral del temple (figura I9). La pintura segueix una iconografia molt típica dels retaules del Roser que trobam reproduida a gran quantitat de temples mallorquins, sobretot en els que tenien dedicada una capella amb aquesta advocació. En grans eixos, veim la Mare de Déu en el cel envoltada d'amorets que aguanten un rosari decorat amb una rosa $i$, en el cim, s'hi troba una 
corona de roses. A la part baixa, hi ha agenollats els personatges de sant Domingo i de santa Catalina de Sena, que també pertanyia a l'orde dominic, amb la corona d'espines al front amb una creu, el crani i un lliri davant. Pel que fa a l'escena, sembla que tingui l'origen en la tradició sorgida a partir del segle XV, en què la Verge del Roser aparegué a sant Domingo a Albi ${ }^{114}$. Aquí veim com la Verge sosté el rosari que serà donat al sant i, de la mateixa manera, el Nin Jesús sosté un altre rosari per a la santa.

Tal com hem dit, estem davant una devoció i una iconografia d'àmplia difusió a Mallorca, promoguda i difosa davall l'abric de l'orde dominic i reproduïda de manera abundant. Per exemple: a Llucmajor, s'hi conserva la pintura que també tapava el cambril del Roser a la planta noble del Casal Rectoral; el taller dels López en realitzà diverses, així com teles individuals per a domicilis particulars (se'n troba alguna en el fons del Casal de Sant Pere i Sant Bernat de Palma) ${ }^{115}$. A més, gràcies a la difusió gràfica mitjançant les xilografies de la impremta Guasp, era una icona a disposició de tothom. Vegeu-ne la interpretació en un treball gràfic d'aquests impressors (figura 20).

La làmina reprodueix en un grau elevat la pintura feta per Sanxo, mentre que pels voltants es troben els misteris del Roser que també hem trobat, d'idèntica manera i ordre, en el programa del retaule que tractam. El gravat torna a mostrar la Verge i el Nin Jesús que ofereixen el rosari a sant Domingo i a santa Catalina. A la vegada, la figura del Roser també porta una corona de roses aguantada a cada banda per uns àngels. El centre és obert mitjançant un paisatge, en el primer pla del qual s'hi entreveuen alguns dels atributs dels sants representats: un ca en el cas de sant Domingo i un lliri en el de santa Catalina ${ }^{116}$.

Entre les pintures conservades en aquesta localitat de Pollença, crida l'atenció la que actualment presideix la capella de la pila baptismal de la seva parròquia, una tela que formaria part de l'antic retaule parroquial i que també devia ser usada per tapar el nínxol. Té clares semblances compositives, cromàtiques i formals amb l'estil del taller dels Sanxo, per la qual cosa ens sembla adequat fer-ne referència cap a un possible cercle comú ${ }^{117}$.

\section{Altres obres dels Oms a Pollença}

A causa del treball que realizà per al convent dominic de Pollença, es pot dir que el taller dels Oms era una nissaga de pintors $i$ escultors prou coneguda en aquesta vila. Justament per això, no serà estrany que, en estudis futurs, els anem

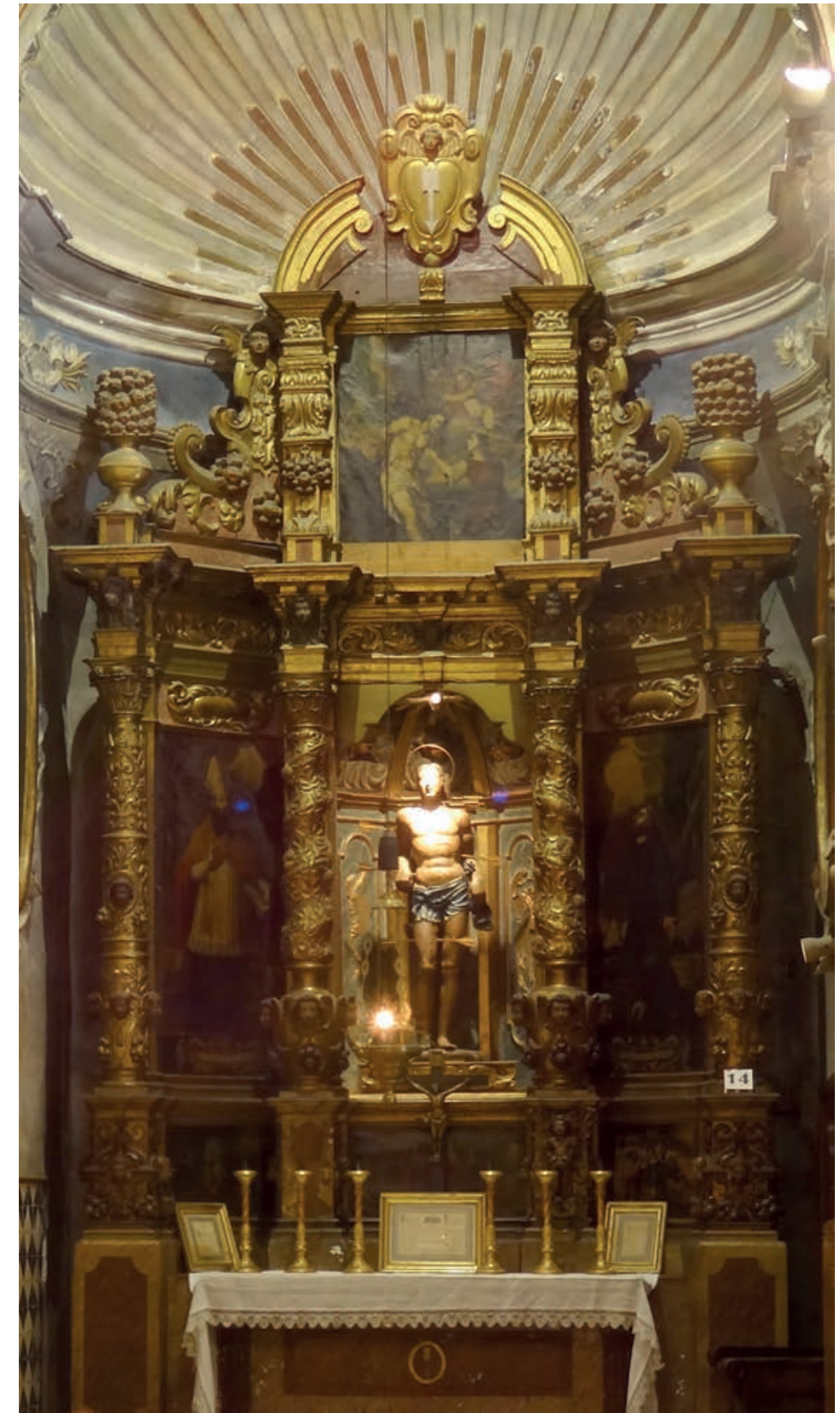

Figura 21

Retaule de Sant Sebastià. Joan Antoni Oms Arbona, 1700-1706. Parròquia de Pollença.

trobant en altres projectes, entre els quals en podem avançar alguns que realitzà Joan Antoni Oms, que devia ser l'Oms i Arbona que hem vist, perquè era l'escultor que en aquell moment estava treballant a Pollença. Un dels clients principals de l'artífex fou l'església parroquial d'aquest lloc, a més d'alguna de les seves confraries. Com veurem, hi va treballar de manera continuada durant les primeres dècades del segle XVIII. Al començament d'aquesta centúria, l'escultor havia aconseguit que gran part de les confraries del temple (entre d'altres, la de Sant Miquel i la de Sant Sebastià) li encarreguessin diversos treballs. 
La confraria de l'Àngel de la Guarda d'aquest lloc el va contractar perquè realitzàs tasques de daurat, tant d'aquest àngel com de l'arcàngel sant Miquel. No sabem si el mateix escultor s'encarregà de tota l'obra, però, l'any I70I, sí que en va fer el daurat dels dos àngels titulars ${ }^{118}$. Amb les intervencions posteriors del segle XIX, l'Àngel de la Guarda degué perdre el retaule, emperò la figura monumental que disposava la confraria és segurament la que es conserva damunt el batiport del portal lateral del temple. Aquesta confraria, a més, degué quedar satisfeta amb el treball de l'escultor, perquè, al llarg dels dos anys següents, li encarregà que creàs un pas amb la figura del rei Herodes per treure'l durant la processó del Dijous Sant ${ }^{119}$.

Aquesta feina també la veurem en l'obra d'una altra confraria, que, si bé no se'n registrà l'escultor, no sembla que s'allunyàs del taller dels Oms. Aquests treballs devien ser de baixa qualitat artística, perquè es tracta de figures destinades a processons, la creació de les quals es pot contemplar no tant a manera d'obra escultòrica $\mathrm{i}$ permanent, sinó més aviat amb un grau de fabricació tècnica i conformada a manera de concepció teatral i efímera, amb poca tasca escultòrica, creació d'imatges de poc pes, amb tela encolada i relleus de guix. En resum, unes peces fàcils de transportar i que només serien usades esporàdicament. L'adquisició d'aquesta tipologia escultòrica no era nova en el temple, perquè, cinquanta anys abans, la Confraria de Sant Jaume ja havia adquirit un altre pas i, a més d'haver encomanat, el I653, un bust de sant Jaume a l'escultor Joan Antoni Oms I, duia un pas portacreu i el 1665 s'encarregava d'alguns complements ${ }^{120}$. Un conjunt de peces que, pel que sembla, es movien dins d'aquest cercle d'escultors ${ }^{121}$.

Durant els mateixos anys en què es realitzà el pas del rei Herodes, la Confraria del Nom de Jesús havia contractat el pintor valencià Gregori Aleix per pintar la capella ( I697). A banda d'això, aquesta associació estava arreglant i restaurant el pas del Bon Jesús, que sortia en processó durant la Setmana Santa (I699-I700) ${ }^{122}$, unes peces pictòriques o escultòriques que no ens consta que s'hagin conservades. Dins d'aquest món sacramental i teatral de la Setmana Santa, sabem que la Confraria de Sant Sebastià, la qual, com ara veurem, serà un altre dels bons clients de l'escultor Joan Antoni Oms Arbona, s'encarregava de dur un pas de la Verònica ${ }^{123}$.

L'obra més important de la Confraria de Sant Sebastià fou la contractació de Joan Antoni Oms Arbona per realitzar l'actual retaule de Sant Sebastià (I 700-I 706) (figura 2I). D'aquesta associació, ens consta que, al segle anterior, havia encarregat una figura per posar-hi la relíquia del sant, una feina d'autor anònim (I623-
I625), mentre que, cap a la meitat del mateix segle (165I), l'escultor Pere Pou, que ja l'hem vist realitzant unes altres peces de format més petit, els va elaborar sis canelobres per a l'altar. No sabem tampoc a càrrec de qui, però, coetàniament, es daurava el sagrari del retaule anterior $^{124}$.

El bienni de I700-I702 es quan veim que els obrers de la confraria ja inscriuen algunes dades «[...] per aixida del quadro [...]». En els comptes del retaule, s'hi mesclen no només la fabricació d'un sant Sebastià per part de l'escultor Oms, sinó també la restauració d'un altre. En aquest bienni, el cost del treball arribà a les 78 lliures $^{125}$. Durant els dos anys següents, continuaven amb les tasques de transport de la fusta per fer l'estructura del moble amb altres despeses, tant d'escultura com de fusteria i de material d'obra' ${ }^{126}$. L'escultor, en petites partides, cobrà 66 lliures més i el i 705 consten deu albarans que pujaven a 24 lliures ${ }^{127}$. Finalment, el 23 de gener de 1705 i el 26 de gener de l'any següent firmava i elaborava uns certificats amb la totalitat del treball fet i cobrat. El I 705 , Joan Antoni Oms Arbona ho exposava de la manera següent:

Jo debaix firmat Juan Antoni Oms, esculptor, confes tenir rebut dels Honors. Juan Martorell de Padruxella y Juan Antoni Torrandell, obrers que son estats per temps de tres anys immediatament passats de la Confraria del Gloriós Sant Sebastià de la Iglesia Parroquial de la present Vila de Pollensa, en differents partidas fins los dia present cent onze lliuras y set sous dich i i i $\mathrm{L} 7 \mathrm{~S}$ com a par en diffarents albarans de ma mia, y llistas aportadas per dits obrers, de que se los ha donat credit y admes descarrech en las antecedents tres sentencias de la sua Administració y obreria, ço es en la dels 24 Janer I703 de i 8 L en la de 24 Maig I704 en nou partidas de 69 Ls y en la ultima dels 22 dels corrents de $24 \mathrm{~L} 7 \mathrm{~s}$ que tot suma ditas I I I L 7 s Las quls son a comte del valor del quadro de la capella de dit Glorios Sant Sebastia que vaig treballant segons apar del consert ab escriptura privada firmada de ma mia. Per lo que per major claricia encarag(ada) de agena escrita.

En Pollensa als 23 janer i 705 . dich i i I L 7 S Joan Antoni Homs.

A banda de la feina cobrada, pel certificat de l'escultor, es dedueix que degueren realitzar una escriptura per a la fabricació del moble, però no l'hem sabut localitzar. L'any següent, Oms elaborà un altre resum de la labor efectuada durant el i 70 , , un moment en què el retaule devia estar bastant acabat i que només en cobrà 
onze partides per un total de 43 lliures $^{128}$. Després d'aquest darrer any, no ens en consten més treballs.

El retaule de Sant Sebastià va substituir l'anterior, ja present en aquesta església en el segle $\mathrm{XVI}^{129}$. La figura titular que conserva és datada en aquesta centúria. D’altra banda, ja hem vist com l'escultor Oms va intervenir sobre algunes figures d'aquest sant: a més de fer-ne una, en va restaurar una altra. Potser la que restaurà és la primitiva que ara presideix el seu retaule, una imatge d'un gust no gaire aconseguit. En canvi, el moble, si bé ha estat desacreditat en alguna publicació anterior a causa de l'excessiva decoració que presenta, no deixa de mostrar un treball acurat i a la vegada ben aconseguit, a diferència d'altres retaules d'aquest temple, que, en molts de casos, abasten processos constructius de diverses dècades, amb la consegüent varietat d'estils com a resultat final. El retaule de Sant Sebastià forma un conjunt compositiu unitari i realitzat en un marge de temps bastant curt, almenys pel que respecta als elements estructurals i bàsics.

El retaule va seguir els esquemes habituals de l'època. L'estil encara és deutor i romanent de les estructures del sis-cents i no anticipa les composicions arquitectòniques que actualitzarien la retaulística mallorquina a les primeres dècades del segle XviII. Té un bancal i un cos central organitzat en tres carrers. Les columnes salomòniques del cos central són anellades, encara que l'ornamentació no les deixa veure. Els dos carrers laterals apareixen esbiaixats i avançats en els extrems. Al carrer central, hi ha el nínxol amb el titular i, en els laterals, s'hi posaren les pintures de Sant Agustí i de Sant Francesc. L'àtic guarda una pintura del martiri del titular i és emmarcat per uns estípits robustos amb decoració arquitectònica superposada. L'estil dels elements decoratius, tant els arquitectònics com els vegetals, contribueix a produir la sensació que es tracta d'un moble voluminós i pesat. Aquest nou treball té força correspondència amb la retaulística coneguda que realitzava l'obrador en altres llocs.

Finalment, prestant interès a unes altres feines professionals del taller dels Oms, en seguim trobant un altre escultor treballant a Pollença. En aquest cas, però, $i$ amb els anys de diferència de l'obra vista a principi de segle, ja no podem indicar de manera tan clara si correspon a l'artista que hem tractat (Joan Antoni Oms Arbona) o si ja estem davant de peces realitzades per Joan Antoni Oms Batle, perquè aquests treballs no ofereixen cap referència explícita per poder arribar a establir una filiació estilística ni formal vàlida. Aquestes noves peces es feren quan s'estava duent a terme l'obra constructiva de la nau de l'església. El treball escultòric en altura per als laterals dels murs era realitzat per Joan Antoni Oms, qui obrà els escuts d'armes que s'hi posaren, com també els capitells de les capelles. D'aquest treball, en són exemples les armes del Batliu de Pollença forjades l'any $1730^{130}$, mentre que, durant el bienni següent (I73 I-I732), s'encarregà de fabricar els capitells de les capelles laterals o de recompondre el retaule de Nostra Senyora dels Goigs, que es trobava a l'oratori de Sant Jordi ${ }^{131}$. A més, realitzà els capitells sobre els murs del temple, i no el finalitzà fins al $\mathrm{I} 738$, amb els acabats i la copinya del presbiteri $1^{132}$.

D'altra banda, en tota la documentació exhumada, hi trobam exemples de peces escultòriques, però de caràcter efímer i d'ús personal, per ser usades en funcions teatrals o de religiositat popular, com les que hem vist per als passos de Setmana Santa. Així, podem informar sobre altres treballs menors que duien a terme els tallers d'escultura d'aquella època i que no són les produccions clàssiques que se sabia que elaboraven (retaules, escultura, etc.). Es tracta d'objectes d'ús individual, com ara màscares teatrals i collars, entre d'altres, i que es realitzaven per a les representacions de diversa índole, tant per a espectacles festius o teatrals com per aconseguir doblers per a la mateixa fàbrica constructiva ${ }^{133}$. No cal oblidar que aquesta vila de Pollença ha estat un dels centres de l'illa amb més tradició d'espectacles teatrals de carrer o litúrgics, alguns dels quals encara estan actius i requereixen aquesta escultura lleugera i efímera que els tallers de l'època moderna també hem vist que creaven. Com a exemple, explicarem que la processó que se celebra per a la festivitat de Sant Sebastià usa, encara, dues figures de cavalls de cartró, i la processó del Corpus és oberta per dues figures femenines que representen unes àguiles.

\section{Conclusions}

El retaule dominic del Roser de Pollença ens ha servit, gràcies a la nova documentació consultada, per poder veure el llarg marc temporal que es necessità per a fabricar tot el conjunt completament, a més de l'àmplia nòmina d'artistes que hi participaren. Les memòries i els registres comptables que realitzà aquest convent ens han deixat veure part del sistema de treball que utilitzava l'obrador dirigit per l'escultor Joan Antoni Oms Tomàs, on els fills tenien una forta presència en l'elaboració dels treballs, si bé la direcció requeia sobre el cap de l'obrador. D'altra banda, en el moment inicial del projecte de Pollença, i a causa de la revisió de les fonts documentals 
conegudes, ens ha servit per ampliar l'obra feta per l'escultor, a més de poder ressituar unes altres peces, com ara el retaule del Nom de Jesús. A més a més, també hem aconseguit treure unes altres tasques d'aquest escultor $i$ dels seus collaboradors (Antoni Carbonell i altres), com van ser les feines de taxador amb Joan Baptista Llodrà, un fet que ens ha clarificat, una mica més, algunes parts de la deixa testamental d'un altre artífex de renom, Antoni Verger. Així i tot, potser se'ns han obert noves vies d'investigació amb l'aparició d'un ignot personatge, Joan Baptista Oms, present dins la feina del taller de Pollença just en els anys en què morí l'escultor Joan Antoni Oms i abans que les regnes del taller fossin agafades pel fill Gaspar. Altres obres, tant pic- tòriques com escultòriques, també han sortit de l'anonimat, amb la qual cosa s'ha ampliat el catàleg d'artistes mallorquins ja coneguts: Andreu Carbonell, Esteve Sanxo, Jaume Comelles, Pere Pou, Rafel Torres i altres membres de la nissaga Oms, especialment els germans Oms i Arbona. Aquests artífexs participaren indistintament tant en el temple conventual dels dominics com en la seva parròquia, on van realitzar les obres clàssiques d'aquests obradors i també unes altres peces de caire més popular o efímeres, com les que ens han aparescut al llarg del treball, una mostra de la producció que es va fer a Pollença i que enriqueix l'ampli i variat ventall d'elaboracions plàstiques que es van crear als obradors illencs durant aquesta època. 
1. M. Rotger Capllonch (1995), Historia de Pollensa, tom 2, Pollença, p. 190-210.

2. J. Lladó i Ferragut (1971), «Datos para la historia de las Bellas Artes de Mallorca», BSAL, 33, p. 378 .

3. M. Carbonell Buades (2002), Art de cisell $i$ de relleu, Palma, J.J. Olañeta ed.

4. G. Fiol Pons (2010), El taller de l'artista a Mallorca els segles XVI-XVII: La nissaga dels Oms (formació, materials, tècniques, procediments i fonts), Palma, UIB, memòria d'investigació inèdita.

5. En referència a la construcció orgànica de les masies, hom recorda el que explicava el Dr. Xavier Rubert de Ventós: en base a un nucli inicial, l'edifici s'anava ampliant o remodelant segons les necessitats i les possibilitats de les persones que hi vivien (X. RUbERT DE Ventós (1968), Teoría de la sensibilidad, Barcelona, Ediciones Península). També E.H. Gombrich, en alguns dels seus estudis, apellava a la precaució en referència a tota obra artística, especialment els edificis, indicant que molt pocs començaren i acabaren amb un mateix projecte. En aquest aspecte, no s'ha d'oblidar que encara es vivia dins un marc gremial de poca separació entre el concepte actual d'artista i el d'artesà. Vegeu, per exemple, com Torras i Tilló justifica l'aplicació en el títol d'aquests dos termes en el pròleg del seu treball sobre la Llotja de Mar de Barcelona: S. Torras I Tilló (2001), Mare Aureum: Artistes $i$ artesans de la Llotja de Mar de Barcelona a l'època del Renaixement, Barcelona, MMB, p. 7-17.

6. Per exemple, les confraries o els retaules que surten a les visites pastorals de la parròquia i que també ens ajudaran a situar els apartats posteriors eren els següents: ADM. Visita pastoral (VP). 1616: Sant Miquel, Sant Jaume, Sant Antoni, Sant Cristòfol, Ànimes, Nom de Jesús; ADM. VP. 1687, f. 393 i s.: Altar Major, Sant Jaume, Sant Antoni, Sant Cristòfol, Ànimes, Nom de Jesús, Santa Anna, Sant Sebastià, Assumpció, Sant Josep, N.S. Concepció; VP. 1692, f. 131 i s.: Altar Major, Sant Jaume, Sant Antoni, Sant Cristòfol, Ànimes, Nom de Jesús, Santa Anna, Sant Sebastià, Assumpció, Sant Josep, N.S. Concepció; VP. 1725, s. f. En aquesta visita, hi cita les confraries: Conf. Santíssim Sagrament, Conf. Nom de Jesús, Conf. N. Sra. del Goig, Conf. Sant Josep, Conf. Sant Mi- quel i l'Àngel Custodi, Conf. Santa Elisabet, Conf. Sant Sebastià, Conf. Sant Cristòfol, Conf. Sant Francesc Xavier, Conf. Sant Jordi, Conf. Sant Jaume i los Sants Metges. A la visita de 1747 i a la de 1753 , s'hi citen gairebé les mateixes, sense cap incorporació; a la VP. 1779, com també a la de 1787 i a la de 1797 , se n'hi troben alguns de variades o d'incorporades: Sant Cristòfol, Santa Llúcia i Sant Lluís Gonzaga. De totes maneres, aquests inventaris són parcials. Per exemple: el 1599 ja existia una capella dedicada a l'Assumpció que s'havia acabat de fabricar, i Antoni Martorell, doctor en Teologia de la Seu, havia fet fabricar un retaule de Nostra Senyora de la Concepció: ADM. APP. 846, f. $69 \mathrm{v}$.

7. ADM. Arxius parroquials Pollença (APP.), n. 459. Les altres unitats que utilitzarem i que hem localitzat d'aquesta confraria seran les següents: 429, 801, 802 i 803.

\section{ARM. AH-1916, f. 68. Cal} mencionar que es troben, almenys, dues publicacions que ja apuntaren cap a la participació d'Oms, els Ballester i Comellas en el retaule del Nom de Jesús del convent dominic: M. Gambús (1998), «La configuración arquitectónica del edificio desde los orígenes al siglo XVIII», Ajuntament de Palma. Historia, arquitectura y ciudad, Palma, p. 98; R. Rabassa (1996), Història de Pollença: síntesi, Pollença, p. 114-115. Si bé la localització i l'estudi de les obres, així com la problemàtica amb les fonts, no han estat tractats.

\section{G. Llompart (1972), «De-} voción e iconografía popular del nombre de Jesús en la isla de Mallorca», Mayurqa, 7, p. 57-58.

10. G. Llompart (1972), «Devoción e iconografía...», op. cit., p. 60.

11. Desenvolupam aquest aspecte donant per fet que no hem tornat a confondre els centres ni les confraries i que la documentació d'aquest apartat, així com unes altres confraries i obres que desenvoluparem, corresponen al lloc que apuntarem.

12. ADM. APP. 429 , s. f., 8 de febrer de 1582. En algun altre lligall, hi queden registres parcials d'aquest pintor, així com del pintor Pere Marcer: ADM. APP. 426, f. 2v., f. 14r.: «3 albarans pagats a Bart ${ }^{\circ}$ Torres habitador de la Ciutat de Mallorca consignatari de Alonso Ruiz, pintor, per lo que li era degut de pintar lo retaule de dita confraria y $\mathrm{p}(\mathrm{er})$ pagar algunes despeses [...] 7117 s 6 d; me. Pere Marcer, pintor, per la pintura del retaule [1591]».

13. ADM. APP. 426, 2n quadern, f. 71 r.: «Vuy als 197 bre 1660 dits obrers me ha[n] entregat un albarà de trenta y tres 11 [...] les quals han pagades a me. Rafel Torres scultor a compliment de una figura del bon Jesús ha fet per dita confraria. Albara de 4 agost 1660».

14. A.J. Villalonga Vidal (2003), Pleits I art religiós a Mallorca segles XVI-XVIII: La sèrie documental Causes Civils com a punt per a la Història Social de l'Art, Palma, UIB, tesi inèdita, 2, p. 397.

15. GEM, 18, p. 389, i M. CARBonell Buades (2002), Art de cisell..., op. cit., p. 20, 27 i 93.

16. ADM. APP. 845 , s. f. Aquestes figures baldament fossin citades que estaven dins l'armari de les relíquies eren les que no disposaven de relíquia. En canvi, sí que tenien relíquia una estàtua de santa Catalina de Sena juntament amb catorze reliquiaris de fusta platejada. Sis d'aquests reliquiaris són, com veurem, els que fabricà l'escultor Andreu Carbonell a la primera meitat del segle xvirI. Un inventari més posterior, datat el 1860 , recull dues Verges del Roser, no una com a l'anterior.

17. ARM. AH-1916, f. 10v., 28 r. Dotze anys abans, es compraren guarnicions per brodar la vesta de la imatge citada com a: «[...] per la vesta del bon Jesús». Potser unes túniques, o, simplement, per la camisa del Nin Jesús.

18. ARM. AH-1916, f. 31r.-v. (1601), «Item a 11 de maig pagaran sinc sou y vuit per un quartio de carn que deviem (?) a me. Joa(n) Sagarra en co(m)pte de lo q(ue) li deviem (j) p(er) lo tabernacle... 5 s.; Item havem tret per gastos al pintor qui feu lo tabernacle».

19. Sobre l'escultor Joan Sagarra i el seu context artístic i familiar, podeu veure un treball amb la darrera obra coneguda: M. Pou Amengual (2014), «Sobre la retaulística de Binissalem durant l'època moderna: Les intervencions de Joan Sagarra i Joan Antoni Oms», BSAL, 70, p. 167-171. En aquesta mateixa edició de la revista, sorgí informació secundària d'aquest escultor: $F$. Molina Bergas (2014), «Jerarquía y poder en la cofradía de pintores, bordadores y escultores de la Ciudad de Mallorca (1590-1602)», $B S A L, 70$, p. 141-164.

20. ADM. MSL-189. 
21. M. Carbonell Buades (2002), Art de cisell..., op. cit., p. 94 i s.

22. ARM. Protocols. T-531, f. 193v.-194r.

23. M. Carbonell Buades (2002), Art de cisell..., op. cit., p. 30.

24. ARM. Protocols. T-535, f. 132v. $-133 r$.

25. ADM. APP. 451, Confraria Sant Jaume, f. 53v.: «[...] dites 12 1118 s. a me. Joan Antoni Homs, sculptor, per bon compte per una bulta per posar la reliquia de St. Jaume $[\ldots] »$.

26. ADM. IV/15/3, f. 1r.: «[...] volgué [l'escultor Verger] que fos cregut mestre Jaume Blanquer de tot lo que divia ser necessari per la contrucció de dita capella [...] y en lo entre tant que dita capella se acabaria, vol, y mana que la sua heretat estiga en poder de curadors y de ninguna manera s'entrega a son hereu, ni se paguen ninguns llegats profans fins sia la dita capella acabada $[\ldots] »$.

27. ADM. IV $/ 15 / 3$, f. 5 r. $-10 v$ Aquesta documentació, a més, ens deixa el testimoni de la família de l'escultor Verger, atès que el germà sastre, Jeroni, l'havia fet usufructuari o hereu si els descendents o l'altre germà sabater no la rebien.

28. Vegeu-ne els estudis: M. CARBONELl Buades (1995), «Jaume Blanquer y el retablo del Corpus Christi», a A. PAscual (coord.), La Catedral de Mallorca, Palma, J.J. Olañeta, p. I 35-I 47 i nota 39, i M Carbonell Buades (2002), Art de cisell..., op. cit., p. 85 i s. Verger i Blanquer eren coneguts i treballaren en projectes comuns, com ara el Consolat de Mar de Mallorca. L'herència de Verger, com veurem, dugué bastants conflictes entre els hereus.

29. ADM. IV/15/3, f. 3r.-4r.: «[...] se entregà a lo hereu doctor Antoni Verger de la dita heretat y ha pasat tant temps que es mort ja lo dit Jaume Blanquer y el retaule del davallament de la creu especialment designat lo ha venut dit doctor Verger, y apres es mort y lo principal de la sua heretat y del dit Antoni Verger testador que es un Rafel situat [...] se es venut per la cort de Magnific Balle y esta vuy per ditribuirse $[. .]$.$» .$

30. ADM. IV/15/3, full solt, s. f. El pintor Joan Baptista Llodrà, o potser un fill, també pintor, estava relacionat amb el convent agustí de Ciutat $i$ actuava de testimoni entre els frares del convent i els administradors de l'heretat del forner Pere Gali durant el novembre de 1675: ARM. Protocols. B-667, f. 438r.443r. En aquest cas, tenim el dubte de si és el pintor o un fill, perquè, en el document, cita el nom amb un adjectiu poc clar, que tant pot referir-se a minor com a maior.

31. ARM. AA. 386, f. 408r.-409r. $D$ 'aquest fet, potser en resulta que, en el cim del retaule, es fes l'escut amb dos llinatges: Bauçà i Verger.

32. ARM. AA. 387, f. 26 i s.

33. ARM. Clero. C-158, f. 251r.252v. Aquest succés passava el gener de 1633, quan el notari Antoni Carbonell fou cridat pel prevere Gabriel Verger i se li demanà que anàs a la casa de l'escultor a aixecar l'acta. L'escultor es trobava en el llit a causa de la gota que patia, símbol de la classe benestant. El notari fou requerit perquè, el desembre anterior, el nebot havia sol-licitat a l'escultor que fes donació d'un dret d'aigua que havia comprat a Agustí Girard pel rafal que tenia davant la Creu de Sóller. L'escultor havia acceptat, però, a causa d'això, el nebot es jactava de la donació i feia creure a la població que havia rebut tots els seus béns. A l'escultor, això el preocupava, perquè li podia limitar les actuacions mercantils o legals. Entre altres tràmits de l'escultor Verger, el podem trobar també el setembre de 1631 fent alguna donació a la vídua de Monblanch, Margalida Vidal: ARM. AH-855, f. 172r.-173r. Aquest escultor, a més del seu pes dins el món escultòric mallorquí, era un personatge també dotat per al negoci mercantil i per establir equilibris comercials a benefici seu. Vegeu un darrer estudi que exemplifica aquesta faceta a: F. Molina Bergas (2013), «Nuevas aportaciones sobre Antoni Verger, sculptor», BSAL, 69, p. 191-203.

\section{A. Furió (1946), Diccionario} Histórico de los Ilustres Profesores de las Bellas Artes en Mallorca, Palma, Editorial Mallorquina, p. 123. Sobre el compendi matemàtic, sembla que es tractaria d'una traducció d'una obra italiana, més que no pas un treball original del pintor (M. Carbonell Buades (2005), Miquel Pont Cantallops: 1675-1755: un pintor llorenci entre Mallorca i Roma, Barcelona, Ajuntament de Sant Llorenç des Cardassar, p. 22, nota 11). En canvi, el dedicat a rellotges de sol, si es localitza, podria contenir tant mostres de manual com els dissenys que degué fabricar.
35. ADM, APP, 597, f. 111r.-v.: «Mes ha pagat amb vale dels 26 dits a me. Miquel Carbonell, pintor y Ant(oni) son fill, escultor trenta una lliures dos sous y vuit y son per la escarada de compondre el quadro de lo Altar Major, fer l'escultura li faltava axí dins los tres palms lo han exemplat, com a los demés donant-li tres pesades de guix, pintar la pastera de la Mare de Déu y la portate del sacrari, pintar la capella de les santes reliquies fins a los escalons y fer tres rellotges de Sol, dos a la plasse y un al mercat havent-li de donar llenyam, picapedrer, fuster per valor de 30 ll. Per lo que se li ha affegit o per fer el nom de Maria en lo escut y lo demés de la deffinició del quadro $=1112 \mathrm{~s} 8$ qui no contara en lo escarada y axí van fora [...] 31 112 s 8».

36. M. Pou Amengual (2015), «L'art del set-cents...», op. cit. A més, en l'aspecte biogràfic, Miquel Carbonell es relacionava amb l'escultor Miquel Cantallops i el pintor Melchior Borràs. Tots tres formaven part del mateix grup religiós, que era la Confraria de Sant Joaquim, establerta en el convent dominic de la capital mallorquina. Fins al 1720, Carbonell vivia en el carrer del Born de Santa Clara i es mudà els anys següents al carreró de Dusai, entre el carrer del Sol el Call. Se'n donà de baixa a partir de l'any 1731 , perquè havia passat a ser deutor de la quota associativa: ADM. MSL/37, f. 23, 75, 97, 144 i 147.

37. ADM. APP. 429, quadern solt, s. f., any 1651, i M. Rotger CAPLLONCH (1995), Historia de..., op. cit., p. 211

38. ADM. APP. 429, quadern solt, s. f., anys 1651 i 1652.

39. ADM, APP. 429, quadern solt, s. f., any 1661 .

40. ADM. APP. 429, quadern solt, s. f., any 1653: «[...] item per lloguer de macho per venir mestre homs per concertar lo fer del retaule deu reals castellans [...] $1 \mathrm{ll}$ 8 s 4».

41. ADM. APP. 426, 2n quadern, f. $67 \mathrm{r} .:$ «[...] pagaren a me. Pere Pou per los peus [?] y mans del pas de la coronació de espines tres lliures» (1653). Cal advertir que aquí no en surt esmentada la professió, encara que, per les peces, sembla que en sigui. De totes maneres, també se sap que, en aquesta època (1659), hi havia un homònim que firmava com a fuster: ARM. Protocols, B-673, f. 53. 
42. ADM. APP. 429, quadern solt, s. f., anys 1653 i 1654 : «Item a me. Joan Antoni Homs als 10 9bre 1654 [...] 26 ll; Item a me. Homs per la susdita raó [...] 211l; i el 1655: 10 lliures el 2 de juliol i 15 lliures més el 15 de novembre».

43. ADM. APP. 429, quadern solt, s. f., anys 1653 i 1654.

44. ADM. APP. 429, quadern solt, s.f.

45. ARM. Protocols. T-539, f. 40r. Elisabet mor el setembre de 1652.

46. ARM. Protocols. T-536, f. 39v.-40, 118v.-119r., i M. CARBoNell Buades (2002), Art de cisell..., op. cit., p. 108 i nota 334

47. ARM. Protocols. S-447, f. 58r.

48. ARM. Protocols. B-669, f. 10r.-11v. Vegeu-ne, d'altra banda, l'estudi concret de l'escultor a: $\mathrm{M}$. Carbonell Buades (2002), Art de cisell..., op. cit., p. 108-109.

49. ADM. APP. 429, quadern solt, s. f., anys 1662 i 1663: «Item per aportar de Ciutat quatre pintors y eynes [... $2116 \mathrm{~s}$; Item aportar lo tornern a Ciutat $7 \mathrm{~s}$; Item a me. Homs trenta sis lliures sinch sous y dos a cumpliment de 600 ll té rebudes a bon compte per lo fer del retaule fins als dos de maig 1663[...]». En els comptes, més endavant, s'hi troben detallades les partides cobrades: el 1663, a l'agost, torna a rebre 60 lliures; mentre que el 23 de desembre de 1655 , n'havien estat 15, i el 22 de febrer de 1656, 30 lliures més. Aquest darrer any, cobrà 75 lliures en tres cops; el 1657, 25 lliures, i el 1658, 10 més. El 1658, s'havia desplaçat a Pollença $i$ en va rebre 86 lliures. I pel juny, dues vegades, foren 49 lliures. I així periòdicament.

50. ADM. APP. 429, quadern solt, s. f., any 1661. A l'octubre de 1661, el fill cobrava 25 lliures, i un escut una altra vegada. Aquell any, arribaren de Ciutat dos pintors anònims amb un ferrer per realitzar les tasques del retaule.

51. ADM. APP. 459, f. 1r. (ca. 1663): «Item per ayguardent quant portaven lo retaule $4 \mathrm{~s} 6 \mathrm{~d}$; Item per aportar los esculptors a Ciutat y eynes 111 19s; Item a me. Poquet per posar el retaule $12 \mathrm{~s}$; Item a Me. Homs per mans de Christofol Bosch ab vi blanch $20 \mathrm{~s}$; Item per un poll havè comprat de $\mathrm{Ant}^{\circ}$ Cabanellas de St. Vicenç per les últimes columnes 311; Item per telar dit poll y port vint sous». L'any següent, Oms encomanà alguns oficis divins: ADM. APP. 459, $\mathrm{f}$. 3r. (1664): «Item per deu misses es dona or de me. Homs se digueren intenció o per los passats lo dia dels morts propassat[...] 111 1. 10s.; Item per tres roves de figures $y$ port anava a demanar dit mestre Homs un escut les quals ha aporta Ant. Quant traginer [...]».

52. ADM. APP. 459 , f. 3 r.: «Item en el dit a bon copmte per fer la figura de P. St. Domingo vint y vuit lliures. Item a mestre Joan Homs o mes fer a Joan fill del sobredit ab diverse svegades quant feya $\mathrm{St}$ Domingo 5 ll 10s; Item a mestre conta després de haver fet lo albara de $28 \mathrm{ll}$ per la figura de St Domingo, per jornals y posar lo retaule de la Parroquia dos lliures de les [...] dos lliures (ja pagades) als 12 9bre 1665. Item per lloguer de matxos per venir y anar los Homs quant se feu la figura de St Domingo, claus y ayguecuyte cinquanta sinc sous».

53. ADM. APP. 459, f. 5r.-v. La figura fou beneïda l'any 1666: «Item reberen dels obrers de St Domingo tres lliures que feren la tarde ques banyren la figura; Item per vuitcents panys de or per la figura de St Domingo $171114 \mathrm{~s}$ 8/ Item a me. Jo[an] Homs a bon compte per deurar la figura de St. Domingo vint lliures/ Item a mestre Joan Baptista Homs a cumpliment per deurar la figura [...] per mans de Martí Aulí clavari [...] 10 $11 »$. Deim «desconegut» perquè no sembla que les investigacions ni la bibliografia artística actual hagin documentat aquest personatge, tret que el fill fos recollit, en aquest cas $i$ excepcionalment, amb un segon nom, Joan Oms, cosa poc probable, perquè més endavant trobarem rebuts firmats per ell mateix amb els dos noms.

54. M. Pou Amengual (2014), «Sobre la retaulística de Binissalem...», op. cit., p. 171-179.

55. Aquest moble de Binissalem iniciat pels Oms fou acabat per l'escultor Pere Joan Pascual, un altre artista que també arribà a tenir una posició benestant gràcies a les seves empreses, i no precisament artístiques, que el degueren fer acostar a la classe benestant de Ciutat. Per això el podem localitzar el 1673 fent de testimoni en una escriptura de la vídua del noble Joan Dameto, anomenada Jerònia Genoin (ARM. Protocols. B-667, f. $331 \mathrm{v}$.).

56. ADM. APP. 459, f. 7r. I els obrers, agraint el gest, feren una petita donació a l'escultor: «Item a me. Homs per un present li feren per haver fet la figureta de Nstra. Sra per lo bassi sens pague dos 1l., deset sous y mix».

57. ADM. APP. 459, f. 9r. (16691670): «Item a me. Joan Baptista Homs escultor, per les polseres de lo ultimo y segona ordre del retaule $3011 »$.

58. ADM. APP. 459, f. 13r., 16r., 17r.-v. i 18v. (1671): «Als 18 fabrer se dona a me. Joan Homs vint y nou 11.10 s.; Als 12 març 1672 se dona ame. Joan Baptista Homs escultor per feyna del quadro [...] [45 ll] [...] Item peer port de venir dit homs dos manobres ayguacuyta y claus [...] Item a un mosso de me. Homs [1 1l. 5s]; (1673) Item als 22 janer 1673 a me. Joan Batista Oms per mans de Bartomeu Cifre traginer nou 11 [...]; Item a me. Homs a bon compta per lo fer de la pastera 20 ll». A aquest rebut en segueixen uns altres per a l'escultor (10 lliures i 15 lliures) més uns altres per als fusters que es desplaçaven des de la capital (1674). Aquests anys, Joan Babtista segueix cobrant per la decoració i per la pastera.

59. ADM. APP. 801 , s. f.: «Jo de baix firmat Juan Batista Homs tinc rebut del Fr. Jaume Costa, rector de la confraria del Roser vuytanta y tres 1l. Dic 83 1l. y son acompliment de la diffinició del retaule he treballat en lo cont. de Pollença. Fet als 6 octubre 1669. Dic 8311 . Joan Batista Homs / Jo debax firmat Juan Baptista Homs escultor tinc rabut de Barttomeu Llobera facdrí y mestre Jaume Soliveras Ciarroui (?) hobres lo present any de 1670 vint y sinch lliures y son a bon compte de mes degut per el retaule de nstra Sra del Roser [...] vui als 10 de novembre de 1670 . Dic 25 1l. Joan Batista Homs / Mes jo [...] he rebut dels sobradits clavaris [...] 30ll. a compliment de tota la feina he feta fins los dia present en el retaule de nostra Sra. Del Roser de la present vila. Fet als 24 novembre 1670. Dich 3011 . Joan Batista Homs./ Mes jo [...] mestre Juan Baptista Oms escultor he rebut dels sobredits clavaris setante y sinch lliures dich 75 ll. y son a compliment de tote la feyne he feta en el quadro de nostre Sre.. fins el dia de vuy que contam als 12 Mars 1672. 75 ll. Joan Baptista Homs».

\section{ADM. APP. 459, f. 27 r.}

61. ADM. APP. 459, f. 29r. i 30r.: "Als 12 de juny 1684 se ha treta de dita caxa per comprar mil panys de or per daurar la pastera [...] 22 1110 s.; Més als 16 juliol 1684 [...] per comprar quatre cents cinquanta 
anys de or [...] més per aportar mestre Homs [...] a Ciutat».

62. M. Carbonell Buades (2007), «Els escultors barrocs de la família Oms: Precisions biogràfiques i noves contribucions al catàleg», $B S A L, 63$, p. 105.

63. ADM. APP. 459, f. 30r.-31v., 37r.-38r., 41r.-43r. (1684): «Més per les mans y colors de deurar la pastera mestre Joan Ant. Homs (20 11); [...] deset lliures que reb me. Joan Ant. Homs conforme albara de 5 de juliol 1682; Més dit dia (29/06/1688) havem gastat sis lliures y sis sous ... a mestre Joan Antoni Homs a conta del sacrari dich; Més als 31 de 8 bre per serrar dos [...] de lleñam per el sacrari (16 s); Primo als 18 de 9bre 1688 [...] (20 1l) a me. Joan Antoni Homs a conta del sacrari [...]; (07/02/1689) [...] per una post de sapi y per llenyam de poll a Cosme Gelabert per fer les columnes del sacrari setze sous; Item a Mestre (J.A.O)[...] aconta del sacrari [...] (11 ll. 10s.); Item per aiguardent per los mestres qui fan lo sacrarai (1 1110 s); Item a mestre Guillem Martí per dos panys, sis frontisses, los perns y tatxes per el sacrari [...]; Item a Cosme Gelabert per un tros de poll per fer dos capitells per el sacrari; Item als 9 març 1689 a mestre Joan Antoni Oms a conta sacrari (3 114 s); Item per 2 jornals de picapedreer de dos mestres y guix per adobar lo altar mayor per posar el sacrari (2 11. 9s)». I els anys posteriors, Joan Antoni segueix amb el treball: 8 d'abril de 1689, 811; 23 de desembre de $1689,16 \mathrm{~s} ; 22$ de gener de 1690, 8 ll, i 1691, 5 ll.

64. ADM. APP. 459, f. 52r., 53r. «Als 21 de 10 bre 1695 per dos mil $y$ cinch cens panys de or per deurar el sacrari (45 ll.); Als 26 juliol 1696 per guix, vermeior y altres colors per deurar y pintar el sacrar [...] (1 ll 16s.); Item per lloguer de dos colcadures per venir e de Ciutat mestre Gaspar Homs y el seu mosso per deurar el sacrari; (1696) Mes a un mosso de mestre Homs (4 s) a conta de la obra del sacrari [...] Mes a Miquel Juan per port de portar Rafel Torres escultor (6 s.); Mes a Gaspar Homs a conta del daurar el sacrari (5 11.); Mes a me. Joan Antoni Homs ab dos partides a conta del daurar (1 11. 9s); Item a Antoni Soliveras per de me. Gaspar Homs devenir de Ciutat segona vegada ab un fadri (15 s); Item a mestre Joan Antoni Oms a conta del deurar el sacrari (14 ll. 8s); Als 23 de desembre 1696 a J.A. Oms a conte (14 ll. 18s)».

65. ADM. APP. 459, f. 53r.-54r.: «Item a Joan Homs, pintor a conta de les figures ha pintades per el sacrari quatre lliures deu sous y vuit; Als 13 janer 1697 a me. Martí Totxa picapedrer per tres jornals per mudar la pastera dins la paret (20 s); Joan Antoni Oms a conta de daurar el sacrari 13 ll.; Als 24 de fabrer 1697 havem pagat a mestre Joan Homs, pintor, dos lliures nou sous y quatre diners a compliment de sis plans pinta a nel sagrari; Item a J.A Oms esculptor (2 ll, 10s. 4d.) a compliment del treball de deurar el sacrari y per los colors que posa en ell».

66. M. Carbonell Buades (2002), Art de cisell..., op. cit., p. 98.

\section{G. Llompart i J. M. Palou} (1988), Nostra Dona Sta. Maria dins l'art mallorquí, Palma, Caixa de Balears, p. 138, i G. Llompart i J. M. PAlou (1993), Eucharistia: Art encarístic, Inca, Govern BalearBisbat de Mallorca, p. 79-80.

68. ADM. APP. 459, f. 59v.-63r.: «Als 1r de maig 1700 de l'acapta per la vila per ajudar a pagar al tabernacle de N. Sra del Roser (7 $115 \mathrm{~s}$ ); Item per quatre fanals per acompanyar a la processó del Sn Rosari [...]; Als 9 abril 1700 a mestre Gaspar Oms, escultor, per el treball de fer una figura y un tabernacle de n. Sra. del Roser $(25$ 11); 25 palms de veta pel doser del tabernacle; [25 d'abril de 1700] per la corona de plata de N. Sra. per portar a les processons (10 ll) [amb diversos rebuts de complements per la figura del Roser de la processó]; [...] lloguer d'un matxo per venir Gaspar Oms i tornar 15s. ; Item per compliment de la corona de plata de N. Sra. del tabernacle 1 1117 s; Item a me. Antoni Estatxe picapedrer per fer lo armari a hont esta el tabernacle de N. Sr. (4 s); 9 11. per acabar de pagar el tabernacle».

69. M. Carbonell Buades (2002), Art de cisell..., op. cit., p. 110-111.

70. R. Carbonell Sans i M. SaLOM FORTEZA (1998), Els retaules de l'Església Parroquial de Sant Pere d'Esporles, Ajuntament d'Esporles, p. 34

71. M. Carbonell Buades (2007), «Els escultors barrocs de la família Oms...», op. cit. p. 105. Vegeu la participació d'aquest pintor $i$, en general, de part de la família Oms en els exàmens i els encartaments del gremi artístic mallorquí: M. Gambús SÁiz i J. Barceló AdroVER (2014), Les Arts a Mallorca entre els Austries i els Borbons: Llibre de cartes $i$ exàmens del col-legi de pintors $i$ escultors començant 1659 fins a 1724, Palma, Lleonard Muntaner, p. 451.

72. ADM. APP. 459, f. 56r.- 57r.: «Als 25 de juliol 1698 a me. Joan Oms, pintor a conta dels quinze misteris pinta pel quadro de Nostra Sra del Roser [...] 6 1l.; Als [30/9/1698] per sis llibres d'or per el quadro sinc lliures, 8 s.; es rep 20 11. $8 \mathrm{~s} .8 \mathrm{~d}$. de diverses devots per pagar les pintures del misteri [...]; Als [5/11/1698] a me. Joan Homs per conta del misteris quinze lliures y sis sous; Als 7/12/1698 a me. Joan Homs acompliment de les misteris del rosari a pintats per la confraria del quadro [...] $2411.9 \mathrm{~s}$ 10 d.; Item per tela, quinta essencia de vernís y port de venir mestre Joan Oms anar a Ciutat y altres ports de roba y color de dit Homs, 8 1l. 7 s. $8 \mathrm{~d} »$.

73. M. Rotger Capllonch (1995), Historia de..., op. cit. p. 190-210. A la visita pastoral de 1602 , hi consta que caldria que, a causa del trasllat del retaule, se'n fes un de nou: ADM. APP. 846, f. 74.

74. G. Llompart (1988), «La devoció Mariana de Mallorca a la història de la pietat i a la iconografía», a G. Llompart i J. M. Palou, Nostra dona..., op. cit., p. 32-34.

75. Vegeu el catàleg G. LlomparT, J. M. Palou i J. M. Pardo (1988), Els López dins la pintura mallorquina del segle XVI, Palma. Hi ha alguns treballs concrets que s'han dedicat, específicament, a l'estudi dels retaules del Roser: J. M. ToRRell Parets (2003), «El retaule del Roser de Vallmoll», Quaderns de Vilaniu, 43, p. 131-146, i A. Pérez (2005), «El retaule de la Mare de Déu del Roser d'Olot», APEHOiC, 15, p. 183-204, entre d'altres.

76. L'abast d'aquest tema és extens, d'àmplia difusió i es troba en nivells distints. Vegeu una mostra que exemplifica la qüestió a: C. Capdevila i Werning (2015), La devoció del Roser a la Diòcesi de Girona del segle XVI al XIX: Confraries $i$ imatges, Barcelona, UAB, tesi inèdita.

77. Vegeu-ne l'estudi de l'aplicació de les estampes de mestres italians $i$ nòrdics a la pintura andalusa d'aquest període a: B. NAvArRete PRIETO (1998), La pintura andaluza del siglo XVII y sus fuentes grabadas, Madrid, Fundación de Apoyo a la Historia del Arte Hispánico.

78. APL. Biblioteca. Breviari, n. 14. 
79. M. Gambús Sáiz i J. Barceló Adrover (2014), Les Arts a Mallorca entre els Austries $i$ els Borbons..., op. cit., p. 24.

80. M. Carbonell Buades (1996), «Torres, Els», GEPEB, 4, Palma, Promomallorca, p. 320.

81. M. Sacarès Taberner (2014), Vivat Ars Lul.liana: Ramon Llull i la seva iconografia, Barcelona, UAB, p. 35, tesi doctoral publicada a l'editorial J. J. Olañeta amb el mateix títol.

82. Podeu veure l'estudi de la seva obra i nissaga a: M. CARBONELL Buades (2002), Art de cisell..., op. cit., p. 111 is.

83. ADM. APP. 913, f. 323v.-330r.

84. ARM. Protocols. T-336, f. 222v.-224r.

85. ARM. Protocols. T-344, f. 165v.-167r.

86. ARM. Protocols. T-338, f. 86 is.

87. ARM. Protocols. S-449, f. 82 83. Alguns dels citats es trobaven a Sant Sebastià i a Pamplona, a més d'actuar-hi altres personatges d'aquestes zones: Pedro Delarragueta, etc.

88. ARM. Protocols. T-339, f. 129v.-131r.

89. ARM. Protocols. 3610, f. 49. El clergue morí el 14 de desembre de 1731 .

90. Catàleg (1950), Colección de xilografias mallorquinas de la Imprenta de Guasp. Tercera edició augmentada, III, p. 495-496.

91. Algunes de les vegades en què trobam citat el fill de l'escultor és els mesos de gener i de març de 1716: «Mes per venir me. Rafel Torres, escultor y son fill de Ciutat y port de trastos, $111.5 \mathrm{~s}$; Mes per tornarsen a Ciutat me. Rafel y son fill y los trastos 1 11. 10s» (ADM. APP. 459, f. 83r.). Per la claredat de les dues citacions, sembla que el procediment de treball era el mateix que a l'època dels Oms i que pare i fill arribaven a Pollença, feien feina alguns dies, o setmanes, i retornaven a Palma. Aquesta vegada no estaren els tres mesos sencers a Pollença, perquè, entremig, consta que l'escultor hi retornà. Pel que fa al fill, encara que no se n'hi recull el nom, suposam que es tracta de Gabriel, el descendent que havia tengut amb Margalida Tomàs i que havia d'ésser l'hereu i el successor de l'escultor. No fou així, perquè el jove continuà el contacte amb l'orde dominic i acabà ingressant com a frare en el convent que tenien a Palma. Això va fer que els continuadors de la nissaga artística fossen els fills que tengué amb un nou matrimoni. Per a aquests altres descendents, vegeu: M. Pou Amengual (2016), «Algunes ampliacions sobre la família $i$ l'obra de Rafel Torres Vezia i dels germans Torres Rubert», BSAL, 72, p. 129-161.

92. ADM. APP. 459, f. 74r.-81r., 83r.-84r., 86r. i 88r.: «Item per 3 mil panys d'or per daurar lo retaule a raho de deset 1l.; Item per anar mestre Rafel Torres a Ciutat 8s.; Item a me. Rafel Torres a conte de deurar [...] 14 11.; Item per dos mil pans de or a raho de deset lliures trenta quatre ll.; Item per adobar la corona de N. Sra del tabernacle 7s., Item per port de aynes de escultor.; A 1 de desembre 1707 a Me. Rafel Torres per compliment de posar 3730 pans de or [...]; Item per dos mil pans d'or [...]; Item a Mestre Rafel Torres ab lo mosso a ciutat als 2 desembre y tornar el 19 janer 17081 ll. 13s; las 16 mars 1708 havem pagat a me. Rafel Torres $10 \mathrm{ll}$. a bon compte de posar quatre mil pans d'or; Item per ayguardent per lo mestres y claus per clavar polseres y angels 111.2 s. 10d.; Item per tornarsen a Ciutat me Rafel Torres ab lo mosso; Item a me. Rafel Torres escultor dotze ll. a compte de la feyna del retaule; Item per dos mils pans de or [...]; Item Rafel Torres esculptor vint y sis ll. per posar los [...]; Item per tornar me Rafel Torres a ciutat $17 \mathrm{~s}$; A me Rafel Torres [...] a bon conte de lo que li deu la confraria per la feyna te feta [...] albara 159 bre 1709 [...] 911 10s.; 26/03/1711, 10 ll, a compte per posar 3000 pans d'or», i segueix cobrant el 21 d'octubre de 1711, el 1712 i el 1713 també uns 3000 pans d'or. A finals d'any, es comptabilitzen 1240 y 4240 pans d'or més.

93. ADM. APP. 802, s. f. / f. 5r.-8r.: «Item a Me. Rafel Torres, escultor als 10 abril 1727 quinze lliures a bon conte dels plans de mitx relleu ha fets per el retaule de dita confraria-15 1l.; Als 17 juny 1727 a me. Rafel Torres, escultor, tres lliures a complt. per dos plans que ha fet de mitx relleu de la banquete del quadro major de Nstra Sra. del Roser---31l.; Més per venir y anar a me. Rafel Torres, esculptor, setze sous.-16 s.; Més a me. Rafel Torres, escultor, a bon conte de les polseres del sacrari de lo Altar major set sous-7s.Més a dit me. Per venir y anar a Ciutat y el cost de dos posts per les polse- res de lo Altar Major una lliura y tres sous-1 11. 3s.; Item per claus per clavar les polseres de lo Altar Major dos sous-2s; Mes a Me. Rafel Torres, escultor, a bon conte de les polseres del sacrari de lo Alta Major en tres partides, dotze lliures catorze sous--- 12 11. 14s.; Més a Me. Rafel Torres, escultor, a complt. de tota la fayne que á fet en el quadro de lo Altar Major de N. Sra. del Roser de este Cnt. Pollença fins lo dia pnt. Als 7 9bre 1728 deset lliures sis sous. Dich a complt---17 11. 6s».

94. ADM. APP. 802, s. f. / f. 19 r. Durant aquesta època, i dins les tasques de decoració, un desconegut soldat citat com a Francisco Valls a ordres del capità D. Pedro Limpio (?) aportava dues estàtues de Sant Pere i Sant Pau per poc més de 5 lliures, si bé aquesta imatgeria sembla que formaria part d'un estatuària privada sense que s'hagi conservat.

95. Hi ha almenys dues còpies del gravat de Sadeler II en col-leccions públiques: Museu Britànic, n. 1949, 1008.77; Reial Biblioteca de Madrid, IX-M-133. Sobre els treballs en dibuix que circulaven per la Península, el conegut àlbum Alcubierre en disposa d'un exemplar: B. Navarrete Prieto i A. E. Pérez SÁnchez (2009), Álbum Alcubierre: Dibujos de la Sevilla ilustrada del Conde Águila a la Colección Juan Abelló, Madrid, Fundación Arte Hispánico, p. 196-197.

96. ARM. Protocols. S-447, s. f., 3 r quadern, 5 de desembre de 1682; 4 t quadern, 3 de juliol de 1683; 6è quadern, 7 de setembre de 1688 , 22 d'agost de 1688 i 28 d'octubre de 1688 .

97. ARM. Protocols. P-1115, f. 45,319 r. El pintor Jacinto Leó el seguim trobant de testimoni en un altre document en què un tal Estarellas feia de procurador del canonge Miquel Torres durant el mes de gener de 1700 , un mateix còdex on trobam l'escultor Bartomeu Ribes fent de testimoni juntament amb el fonedor Miquel Verd d'unes terres que es vengueren el $1686 \mathrm{al}$ municipi de Montuïri (ARM. Protocols. P-1116, f. 44-45, 120r.). El genovès Leó s'examinà de pintura en el gremi de Mallorca el 1690: M. Gambús Sáiz i J. Barceló Adrover (2014), Les Arts a Mallorca..., op. cit., p. 313.

98. ARM. Protocols. S-448, 3r quadern, f. 14; quadern de 1714, f. 13 , quadern de 1715, f. 9 . Eren diversos germans: Carlos, Ana, Magdalena, Enric. Una de les germanes, 
Ana Maria, era novícia al convent de Santa Teresa de Jesús de Ciutat.

99. ARM. Protocols. S-449, f. 23. Aquesta família era formada principalment pels dos germans, Carles $(† 1737)$ i Enric $(† 1763)$. S’havien instal-lat a Mallorca a finals del segle Xvir amb el negoci de mercaders. A més d'enriquir-se amb el comerç marítim, també establiren aliances matrimonials amb mallorquines $\mathrm{i}$ aconseguiren comprar bastants propietats (a Palma, Manacor, Petra, etc.). En temps de Bover, encara subsistia l'estirp: J. M. BoVER (2005), Nobiliario mallorquí, J. J. Olañeta, Palma, p. 178-179, i R. Fernández Legido i G. Valero i Martí (2007), Possessions de Palma, Palma, J. J. Olañeta, p. 4041. Les dades biogràfiques $i$ d'arxiu (testaments, etc.) d'aquesta família es troben recopilades a les fitxes de les finques de Son Palerm i Son Moix de l'adreça següent: <http:// possessionsdepalma.net $>$.

100. ARM. C-2030, s. f. El bisbe Campeggio, de totes maneres, no residí a Mallorca i el govern de la diòcesi fou confiat a un administrador eclesiàstic. El 1558 renuncià al càrrec, però no pas a alguna $\mathrm{de}$ les rendes que li degueren perdurar, com és el cas. Ha estat tractat algun cop, de manera lateral, en referència a l'època del Concili de Trent $\mathrm{i}$ a la presència mallorquina: M. BATLLORI (1944-1946), «Lo Bisbe Jubí», BSAL, 29, p. 424471 , i J. Vich SALOM (1944-1946), «Miscelania Tridentina Maioricense», BSAL, 29, p. 646-649. Formaven part d'una poderosa nissaga bolonyesa, i tant el seu germà com el pare arribaren al cardenalat. Alguns d'aquesta nissaga, d'època posterior, han aparegut citats en estudis sobre art hispànic: D. García Cueto (2006), Seicento boloñes y Siglo de Oro español, Madrid, CEEH.

101. Vegeu dues de les monografies que s'hi han dedicat: $M$. Carbonell Buades (1999), Guillem Mesquida, 1675-1747, Palma, Conselleria d'Educació, Cultura i Esports, i M. Carbonell Buades (2005), Miquel Pont Cantallops (1678-1755): Un pintor llorenci entre Mallorca i Roma, Ajuntament de Sant Llorenç des Cardassar.

102. El darrer treball que ha aclarit l'origen i l'ascendència familiar d'aquest escultor es troba a: $M$. Gambús Sáiz i J. Barceló Adrover (2014), Les Arts a Mallorca..., op. cit., p. 77.

103. ADM. APP. 801 , s. f. Dins del quadernet interior s. f. i grapat.

\section{ADM. III/140/16}

105. M. Carbonell Buades (1996), «Carbonell, Els», GEPEB, 1, Palma, Promomallorca, p. 387388, i M. Pou Amengual (2015), «L'art del set-cents a la parroquial de Maria de la Salut: Els escultors Deià, Bennàsser i els Carbonell», $B S A L, 71$, p. 138. A la capella del Roser de Manacor, on hem vist que treballà en el cambril, també tengué tasques, almenys, secundàries per als retaules laterals (Santa Catalina de Sena, 1707). G. CARrIó Vives (2002-2003), «Jaume Llull, escultor cap al Setcents", Estudis Baleàrics, p. 74-75, p. 178-179.

Tanmateix, el treball que es troba més documentat i extens en aquest lloc és el que realitzà aquest taller a l'església parroquial: A. CARvaJAL i A. Gomila (2013), «La confraria de la Mare de Déu de l'Assumpció: Exemple destacat del món confrare manacorí en època moderna», VII Jornades d'Estudis Locals de Manacor, Manacor, p. 209-239.

106. Tampoc, de moment, sembla que s'hagi localitzat el rastre documental d'aquesta obra dels Carbonell a Manacor, com a molt tasques menors: el 1755-58, el mestre Francesc Aguiló arreglava les vases del Roser i hi afegia algunes vergues de plata, i cap al 1767 un tal mestre Aleix arreglava la túnica de la Verge. Les intervencions del segle XIX també resten parcials: el 1807 s'hi collocava una nova figura i el pintor Joan Riera hi treballava: ARM. AH-1907, s. f. Desconeixem si a aquest retaule del Roser de Manacor se l'ha relacionat, però podria tractar-se de l'actual retaule de Sant Guillem d'Aquitània que conserva el convent de Sant Agustí a Felanitx. L'historiador Pere Xamena recollí que dit retaule provenia de la ciutat de Manacor (P. XAmENA (1994), Visita a l'església del convent de Sant Agustí, Felanitx, p. 32-33). La notícia es va publicar a partir de l'obra de Cosme Bauçà (C. BAuzÀ (1921-48), Historia de Felanitx, tom I, Palma, p. 345). Malauradament, cap dels dos indiquen la font d'informació primària, però ben bé podria ser l'antic retaule dels dominics de Manacor. El moble conserva, al seu voltant, totes les escenes dels misteris del Roser, excepte a l'àtic, que s'hi va instal.lar una nova pintura. D'altra banda, l'obra és acabada amb un escut coronat, una peça molt habitual en retaules d'aquest tipus o d'aquest orde: Pollença, Manacor mateix o en la portada del llibre de la confraria del Roser que hem vist en el primer apartat. A més, s'adequa bastant bé al que pogué veure G. Berard a finals del segle xviı:
«El principal altar es de orden corintio, obrado y adornado con mucho relieve dorado, entre colores y lienzos pequeños pintados, como en otras referidas [...] camaril grande, y al sócolo entre pedestales [...] una imagen de Nuestra Señora muerta [...]» (G. BERARD (1983), Viaje a las villas de Mallorca, 1789, Ajuntament de Palma, p. 143). Fos com fos, tot el carrer central i el nínxol originals d'aquest retaule es perderen amb la reconstrucció.

107. ADM. APP. 802, s. f. / f. 21r., 23r.-v.: «Més al pr. Juliol 1742 a Me. Andreu Carbonell, escultor, vint y dues ll. tretze sous y quatre diners a bon conte de la obra del camaril de Nstra. Sra. dich ---22ll. 3s. 4; Més per la obra del canzell per el portal major de la Iglesia deu 1l.; Més per venir de Ciutat Me. Andreu Carbonell, escultor, per posar el camaril de N. Sra. del Roser tretze sous y sis---13s. 6; Més al pr 8bre 1745 a me. Andreu Carbonell, escultor, sinquanta sis 11. sis sous y vuit diners a bon comte de la obra del camaril. Dich 5611. 6s. 8; Més per 2 posts de llenyam vermei per la obra del canzell una lliura deu sous; Més per una figura de N. Sra. y una de un ca per el portal major de la Iglesia sinch 11. tretze sous y quatre--- 511 13s. 4; Més per port de la obra del camaril tres sous---3s; Més als $187 \mathrm{bre}$ 1746 a Me. Andreu Carbonell, escultor, a bon conte del camaril 12 1l.; Més per el port de anar y venir a este Cont me. Andreu Carbonell, escultor, per la obra del camaril a Pere Sañori, una ll. sis diners; Més per portar a Ciutat Me. Andreu Carbonell, escultor dotze sous.; Més per llenyam per el canzell deu sous».

108. ADM. APP. 803 , s. f. / f. 1 r., 4 i 8r.: «Més als 28 8bre 1748 a Me. Andreu per mans del P. Fr. Juan Coll onze 1l. sis sous y vuit a bon conte de la obra del camaril de Nstra. Sra. dich ---11ll. 6 s. 8; Més als 24 juny 1751 a me. Andreu Carbonell, escultor, vint y dues 11 . deu sous y nou diners a complt. de tota la obra del camaril de Nstra. Del Roser de este Convt fet gracia (-) lo damés amore virginis. Dich ---22ll 20s. 9; Mes per colors guix per pintar el capell del portal major de la Iglesia... 11l. 9s.4; Més a Me. Andreu Carbonell, escultor per mil panys de or per daurar el camaril de Nsta. Sra. del Roser del pnt. Convent denou 1l.; Mes per un pany y clau per la porta del camaril de Nstra Sra.---4s. 6; Més per 1500 panys de pr per deurar el camaril de Nsra. Sra. a raho de denou 11. al milanar, vint y vuit 11 . deu sous. Dich---28ll 10s.; Mes als $20 \mathrm{fa}$ - 
brer 1753 per 1100 panys de plata a differents preus tres ll. nou s. Dich---31l. 9s.; Mes a Andreu Carbonell y a Gabriel son compañero, sis ll. ab dos partides a bon conte del deurar el camaril de Nstra. Sra. dich---61l.; Mes per el port de venir de Ciutat dits manastrals y los seus trastos una ll. dos sous---1ll 2s; Més als 3 abril 1753 tich pagat a Me. Andreu Carbonell, escultor, quaranta set lliures, denou sous y les quals son a complt per el daurar y estofat las figures del camaril de Nsra. Sra. del presnt. Cnv. Dich 4711 19s. 2d.; Mes a Me. Reus per obra del camaril y clau, deu sous y vuit---10s. 8; Més a Pere Miracel alies Flacade per el port de los manastrals anar a Ciutat concluida la obra del deurar el camaril de Nstra. Sra. una 1l.---1 11.; 01/07/1757 essent prior P. Juan Mr. Terrassa prengué de la confraria del Roser per el gasto de fer la custodia de dit convent---51l.13s.4».

109. ADM. APP. 803, s. f. / f. 9r., 10r. i 11r. Durant el mateix temps, també hi ha uns altres treballs no nominals: «Per fer 6 reliquiaris, per adobar 6 canalobres y platearlos per dos escalons, per un peu per la creu de plata, per fer una vaya(?) [caixa?] per pintar los pedestals del Altar Major y adobar N. Pare y la sua pastera essent prior el P. Fr. Miquel Carbonell y[...] 39 1l. 3 s 4; Die 2 8bre 1759 per pagar a me. Andreu Carbonell 6 reliquiaris, 6 canalobres, unes sacres, un escaló y dues cartellas quaranta e quatre ll. tres sous y quatre. Videm la plagueta de albarans del Roser fol 2 que ay albara de dit Carbonell, y es de-----44ll 3s. 4. Per el treball de ramendar, daurar y compondre una figura de Nostra Sra. del Roser qui serveix quan se fan les processons los primers diumenges de mes sis lliures, setze sous consta del albera a la plagueta de albaran dol 3--- 61l 16s.; pel treball de pintar una figura del Roser y un sant Cristo per dita bandera---3ll. 12s (1761); (1764) 2 ll. per adobar l'orgue.S/f (1766); Més se ha pagat 1 11. 10s. Per de la Corona de la Mare de Déu y afegir plata y també mateix la del Bonjesus dich 1 11. 10s».

110. G. Duchet-Suchaux i M. Pastoureau (2003), La Biblia y los santos, Madrid, Alianza Editorial, p. 140 .

111. P. J. Llabrés i Martorell, G. Llompart i J. M. Palou (1992), Santa Maria a Inca, Inca, p. 90, i P. J. Llabrés I Martorell (ed.) (2001), Els sants a l'art d'Inca, Inca, p. 102.

112. ADM. APP. 802. s. f.: «Més a Me. Esteve Sanxo, pintor a bon conte del quadro que es fa de $\mathrm{N}$. Sra. per davant el camaril sinch 11. tretze sous, y quatre per mans del P. Fr. Honorat Castany---51l. 13s. 4; Més a dit Me. Esteve per la sobredita raho, per mans del P. J. Juan Coll---1 1l. 4s.; Més per port de la obra del camaril tres sous--3s; Més als 21 Juny 1746 a Me. Esteve Sanxo, pintor, a complt. el quadro a fet de N. Sra. per davant el camaril, onze ll. sis sous, y vuit diners---111l. 6s. 8».

\section{M. Carbonell Buades} (1996), «Sanxo, Els», GEPEB, 4, Palma, Promomallorca, p. 229230. Sobre la darrera pintura que s'ha identificat d'aquest pintor, es troba en el retaule de Sant Francesc Xavier de Llucmajor: M. Pou Amengual (2015), «Els escultors Ribes: Notes biogràfiques i obra documentada", Locus Amoenus, 13, p. 76.

\section{G. Duchet-Suchaux i M.} Pastoureau (2003), La Biblia y..., op. cit., p. 82-83 i 140.

115. El Museu Arqueològic Diocesà en tenia inventariada una altra amb aquesta escenografia $\mathrm{i}$ els misteris al seu voltant, que havia estat llegada, explícitament, pel museu per Joan Lladó, prevere: R. M. Aguiló, M. M. Gaita i J. M. Palou (s. d.), Mossèn Alcover i la dissolució del Musen Arqueològic Diocesà: Tres inventaris, Palma, Museu de Mallorca, p. 31.

116. Si bé la planxa de la impremta Guasp deu correspondre al segle xviII, la col-lecció Guasp en té una altra de posterior amb els tres mateixos personatges i sense els misteris. Aquesta altra fou estudia$\mathrm{da}$ en relació amb imatges arribades a Mallorca des de fora: M. Forteza Oliver (2001), «Xilografías foráneas durante el siglo XIX en Mallorca», BSAL, 57, p. 203-210.

117. Suposam que pertany a l'antic retaule titular de la Verge dels Àngels, la patrona, titular de la parròquia, i que fou substituït el 1800 pel retaule actual transportat des de l'església local jesuïta.

118. ADM. APP. 450. Confraria de l'Àngel de la Guarda, 1646. Rebut solt: «Jo debaix firmat Joan $\mathrm{Ant}^{\circ}$ Homs sculptor he rebut dels honor Sebastià Cerdà, trencador de pedra y de Joan Sales, gerrer, [...] a compliment de la feina he fet [...] obrers de la confraria del Gloriós Arcàngel Sant Miquel y del Angel Custodi, so es per deurarlos y posarlos en son llochs y per ser esto [...] 3 febrer 1701 [...] 46 1l. Joan Antoni Homs».
119. ADM. APP. 450, f. 30r.-v.: «[...] y a me. Joan Antoni Homs, sculptor per un pas nou ha fet per el dijous St. per dita confraria onze lliures deu sous les quals tres partides fan summa de 2911 [...] fins a compliment de dites $301 \mathrm{ll} 5 \mathrm{~s}$ (anys 1702-1703); (1704) Ço es ab el vestit del Rei Herodes del pas $2111 \mathrm{~s}$ per pintar el pas del Dijous Sant 3 ll».

120. ADM. APP. 451, f. 75r. (ca. 1665): «Al pas del Porte Creu han comprat a nels regidors de lo Hospital Gl per $41110 \mathrm{~s}$ [?] de les llanternes per acompañar dit pas [...]».

121. No sabem si es conserva algun d'aquests treballs efímers documentats, però no devien estar gaire lluny d'un grup del Plany de Crist que recentment ha estat restaurat pel taller del Bisbat de Mallorca. L'obra és un conjunt de vuit figures realitzades amb la tècnica d'escultura lleugera i se suposa que són del segle xvI. Vegeu-ne la fitxa tècnica a $<$ https://tallerbisbat.blogspot. com>: «Restauración del conjunto escultórico del Oratori del Roser Vell de Pollença», 17 de novembre de 2016. Aquestes figures restaurades són bastant modestes quant a la qualitat artística i pertanyen més a peces de caràcter etnològic i de pietat popular. De fet, aquests tipus d'obra, a causa de la seva pròpia naturalesa, són bastant escasses. Una altra la trobaríem amb la Verge Morta de Llucmajor, actualment en bastant mal estat: J. Llabrés i A. Pascual (2008), L'Album de la Dormició de Jeroni Juan Tous, Palma, Consell de Mallorca, p. 124-125. Així i tot, no podem descartar que alguna d'aquestes escultures per a Setmana Santa fossin autèntiques peces d'art. Vegeu la qualitat d'algunes obres efímeres del monument del Dijous Sant que es realitzà per al convent de Sant Domingo de Palma, actualment conservades a l'església de Sant Nicolau: G. Llompart i J. M. Palou (1993), Eucharistia. Art eucarístic..., op. cit., p. 186-187.

122. ADM. APP. 452. Llibre de sentències Conf. Ssm. Nom de Jesús, 1694, f. 3r., 5v., 6v. i 13v. Aquesta vegada suposam que, a diferència de la confraria del Convent, aquesta pertanyia a la parròquia: «[...] mes 31114 s 15 mestre y manobre, clas, guix, y carbó per emblanquinar la capella, mes $10 \mathrm{ll}$ a me. Gregori Aleix, pintor per pintar la capella.; (1699-1700), per una túnica per el pas, renovarlo y fer adobar el bon Jesús del paso $=711$. per el Dijous St.; per la corona del bon Jesús ( 1 ll 5s); (1721) 4 ll 
13 s per el cost del pas per lo Dijous St. [aquí suposam, així com d'altres partides registrades sobre el cost del pas, que era pel jornal i per transportar-lo en processó no per fabricar-lo]; s. f. (1762), més se ha entregat una corona de plata per adorno y porta la Sta figura del Bon Jesús [...] 8 1l»; Sembla, d'altra banda, que, a partir de final de segle (1777-1809), aquesta confraria construí una capella i un retaule sencer dedicat a aquest titular: ADM. APP. 452, s. f. (1777) «Mes los descarrechs d $15 \mathrm{ll} 12 \mathrm{~s}$ procehides de valor del quadro de la capella de dita confraria quel van fent [?]; 1778,51110 s. pel gasto del quadro de dita capella; 1797, en 90 y 91 un estatua del bon Jesús y demés obra feta $143113 \mathrm{~s} ; 1805$, 74 1l. $13 \mathrm{~s}$ valor de la figura del Bon Jesús [...] $91 \mathrm{ll}$ 7 s 6 pel nínxol de dita capella; 1806-1809, 115 ll. 14 s. 10 per estucar capella; 15 ll. $19 \mathrm{~s} 4$ per picar pedres i enratjolar la tarima [...]; 58 ll. $14 \mathrm{~s}$ pagades a l'escultor [...]».

123. ADM. APP. 456. Conf. St. Sebastià, 1623-1705, s. f., 1698: «y el dijous St. per acompanyar el pas de la Verònica a la processó [...]».

124. ADM. APP. 456, s. f., 1625: «[...] adops capella, una figura han feta fer nova ahont sta posat la reliquia de St. Sebatià [...]; 1651, 4(8) 118 sous [?] costaren sis canelobres daurats obrats feu me. Pere Pou, esculptor, $22 \mathrm{ll} \mathrm{me.} \mathrm{Costa} \mathrm{[vegeu} \mathrm{que}$ aquest mestre Costa deu ser el fuster $\mathrm{o}$ torner que acompanyarà deu anys després a Gaspar Oms per a l'elaboració del retaule dominic que ja hem vist]; 1623, a Ramón Marça, argenter, 266 ll. 8s llantia plata [...] mes gastaren $19 \mathrm{ll}$. 10s per una figura del St. per posar la reliquia; 1666, per daurar el sacrari [...]».

125. ADM. APP. 456, s. f.: «[...] com també 4 ll. que pagaren a me. Joan Antoni Homs per haver fet una figura de St. Sebastià y renovarne una altra com també [...] lo gasto de dita confraria que tot $\mathrm{fa}$ suma de [...] 78 1l. 13s».

126. ADM. APP. 456, s. f, 1703: «[...] serrar y portar llenyam per el quadro y posts de sapi [...] $4711.16 \mathrm{~s}$ [...] mes consta haver pagat a me. Joan Antoni Oms, sculptor [...] als 4 bre 17028 1l. y 10 s en dos pdas.; 1704, 3 ll. $16 \mathrm{~s}$ per renovar figura de St. Sebastia; 6 ll. 3 s per pedreny, guix, etc. pel manobre per fer los barbaxos per posar el quadro [...]».

127. ADM. APP. 456, s. f. 5 de març de 1703: 6 11.; 20 d'abril de 1703: 20 1l.; 11 de juliol de 1703: 6 11.; 31 de desembre de 1703: 3 11.; 25 de gener de 1704: 2 1l. 10 s.; 23 de febrer de 1701: 8 ll.; etc.

128. ADM. APP. 456, s. f., 28 de gener de 1706.

129. R. Cifre Cifre (1991), Doscents anys de vida parroquial a Pollença: 1790-1990. Pollença, Punt Gràfic, p. 294. Vegeu, a més, els inventaris de les capelles recollides en aquest mateix estudi a la nota 6 .

130. ADM. APP. 597, f. 4v.: «Als 23 juny dits (1730) Joan $\mathrm{Ant}^{\circ} \mathrm{Oms}$ per treballar les armes del Sr. Balliu a la primera pedra [...] 8s $6 \mathrm{~d} »$.
131. ADM. APP. 597, f. 17v is. 1731: «als 23 juny a me. Oms a compte de son treball en lo capitel menor [...] 14 sous, etc.; A 21 juliol dits se ha pagant a Joan Antoni Oms 4 sous a compte de son treball [...] per tallar los capitells de les capelles [...]; als 22 juny a Joan Ant. Oms per compondre los retaule o, quadro de la capella de Ntra, Sra. dels Goigs en lo Oratori de St. Jordi [...] 4 s. [i altres partides que seguien durant aquest anys, 1732, per capitells blanc, i la seva escultura etc.]».

132. ADM. APP. 597, f. 85r.-v També durant aquestes dècades es troben localitzats diversos membres de la família Oms en treballs del mateix tipus per a la parroquia de Santa Maria del Camí.

133. ADM. APP. 597, f. 36v. i s.: «Als 24 Agost a Juan Ant. Oms a compte de les masqueres per la mageganga [...] 2 s.; Als 31 agost a compte $d$ eles masqueres feu per lo entremig, collars [...] per la comedia 3s.; Als 29 novembre [1732] a J. Ant. Oms, esculptor, a compliment per los dos capitells a les capelles collaterals del presbiteri que son de pedra de Oriulet [?] que ha fabricats y tots los trastos se necessiten per la representació de una comedia [...] $4 \mathrm{ll}$. 6 s. [sobre la representació teatral que es feien no sabem quines es tractava, però vint anys després (novembre de $1753 \mathrm{i}$ el gener de 1754) es deixava contància com es pintava [...] frontis i nubes de les los trabajos de [...] la comèdia de Burguny». 